\title{
LILIANE GARCEZ
}

\section{DA CONSTRUÇÃO DE UMA AMBiÊNCIA INCLUSIVA}

\section{NO ESPAÇO ESCOLAR}

Dissertação de Mestrado apresentada à Faculdade de Educação da Universidade de São Paulo, como exigência parcial para obtenção do título de Mestre em Educação, sob orientação do Prof. Dr. Júlio Groppa Aquino.

SÃO PAULO - 2004 
A Luiz Henrique de Paula Conceição meu grande amor de todas as horas que acreditou em mim como eu custei a fazê-lo.

A meus três filhos queridos: Gabriela, Beatriz e Leonardo, que mostram todos os dias o quanto acredito na possibilidade de construção de um mundo mais feliz. 
Minha gratidão a meus pais Assumpta Galoro Garcez e João Ribeiro Garcez que me acompanham pelos caminhos que escolho, mesmo estes sendo diferentes dos deles;

A meus sogros Maria Lucia Graça de Paula Conceição e Ramon Barreiros de Paula Conceição (in memorian) pelo apoio imprescindível. 
Gracias a la vida

Que me a dada tanto

Me ha dado el sonido e el abecedário com el las palavras que pienso i declaro

Madre, amigo, hermano

I luz alumbrando

E a voz tan tierna de mi bien amado! 


\section{AGRADECIMENTOS}

A tarefa da escrita é árdua. Mais ainda quando tem a responsabilidade de traduzir em palavras um percurso que não se fez solitário. Ao ser levada a cabo, sintetiza de alguma forma o trabalho, os textos lidos, as conversas, a vida em movimento que gerou um objeto público. O projeto deste texto iniciado em 2000 encerra toda a vivência com ele e por meio dele de um aprendizado.

Agradeço ao Prof. Dr. Julio Groppa Aquino que foi intenso em suas colocações e um porto seguro em meu percurso teórico.

Sou grata a Profa. Dra. Leny Magalhães Mrech que confiou na minha capacidade e proporcionou um feliz encontro com o tema, me acolhendo nos primeiros momentos.

Destaco a cumplicidade cotidiana de Tânia Gonçalves que impulsionou o trabalho de escrita como uma leitora sempre crítica e amorosa.

Meus agradecimentos aos amigos que fiz na Escola Municipal de Ensino Fundamental Vianna Moog na relação intensa durante o processo de construção e confronto de idéias, em especial para Joaquina, Eliane, Jussara, Maria Aparecida, Kátia, Cristina, Cida Converso, Ana Paula, Carla, Irene, Jane, Jane Maciel, Maria José, Conceição, Regina Lydia, Rosemeire, Sandra, Ana Maria, Ane, Anselmo, Alves, Célio, Jurandir, Laura, Ivonete, Maria Claudia, Nelsi, Maria Romana, Maria da Glória, Márcia, Patrícia, Stela, Carla Bezerra, Claudia, Regina Márcia, Maria Cristina, Adriana, Célia, Sonia, Tereza, Dilair, Kátia Conceição, Maria Elizabete, Gicélia, Adriana Alves, Adenilte, Esmeralda, Antonia Cristina e Rosângela. As colegas da CEB, antigo NAE 12, Márcia Marolo, Vera, Valdete e Adriana.

Para os professores e companheiros de muitas horas de debate César Augusto Minto, Cristina Harada, Lighia Matsughite, Maria Claudia Junqueira Vianna, Maria da Graça Bollman, Nobuko Kawashita, Rosângela Gavioli Prieto e Rubens Barbosa de Camargo.

Para os companheiros do Fórum Nacional em Defesa da Escola Pública durante as muitas horas de organização dos Coned - Congressos Nacionais de 
Educação e do Fedep - Fórum Estadual em Defesa da Escola Pública e do Fórum Permanente de Educação Inclusiva, pela troca intensa de experiências.

A todos os professores da FEUSP nas pessoas de Selma Garrido Pimenta e Antonio Joaquim Severino.

Aos mestres do curso de licenciatura e da pós-graduação que me ajudaram a entender sobre educação: José Sérgio Fonseca da Carvalho, Cecília Hanna Mate, Marcos Ferreira, Ligia Amaral Assunção (in memorian) e Arakcy Martins Rodrigues (in memorian).

Gostaria de lembrar a fundamental presença dos funcionários da FEUSP. Todos contribuíram de alguma forma para a realização desta dissertação e, certamente, de tantas outras, pois eles tornam a Faculdade mais do que um lugar para a realização de um trabalho acadêmico - um ambiente fraterno. Aos colegas da secretaria de pós-graduação: Cláudio José de Souza Ávila, Edmilson Sousa Santos, Daniela Cristina Matos Borges, Luana Robles Vieira e Rosana Gomez Romero Pedroso, os da Seção de Informática: Moisés, Paulo Roberto e Rafael; às secretárias de departamentos e da diretoria: Nanci, Leia, Márcia, Sandra, Rita, Raquel e Solange meus agradecimentos. Agradeço ainda a todos os funcionários da Assistência Técnica Acadêmica e da Tesouraria nas figuras de Sidney Mauro Fontanetti e Wilson Lima Pisok.

A Marilena Vizentin pelo aprendizado importante com relação a nosso idioma por meio de uma revisão cuidadosa.

Ao CNPq, pelo apoio financeiro. 


\section{SUMÁRIO}

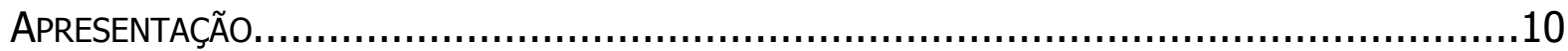

I. Planos NaCionais de EduCAÇÃo: A eduCAÇÃo como "QueStÃo governamental"............18

II. As DiRETRIZES EdUCACIONAIS Do MuniCÍPIO DE SÃo PAULO..................................55

III. A DiAlÉTICA DA INCLUSÃo/EXCLUSÃO NUMA PeRSPECTIVA SóCIO-HISTÓRICA....................76

IV. A INCLUSÃo COMO PARAdIGMA DA EdUCAÇÃo ESPECIAL.......................................100

V. Uma Proposta Metodológica de InterVEenção e PeSQuisA.....................................121

1. A PESQUISA-AÇÃO: CONCEITUAÇÃO TEÓRICA E PROJETO DE INTERVENÇÃO.................121

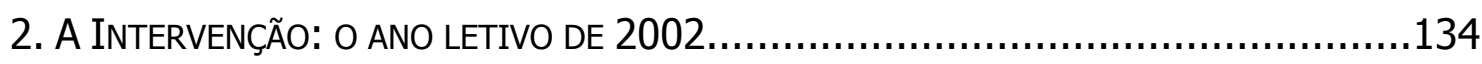

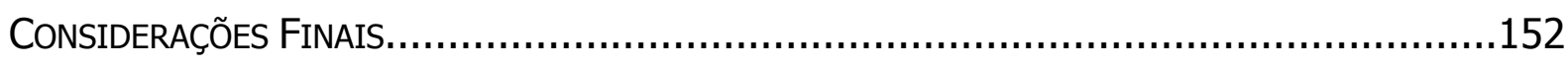

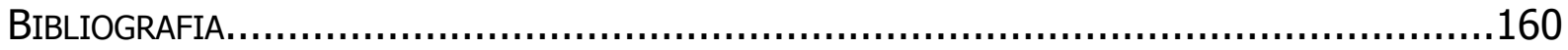

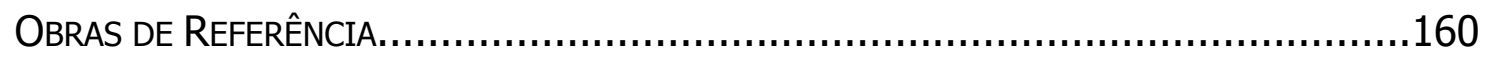

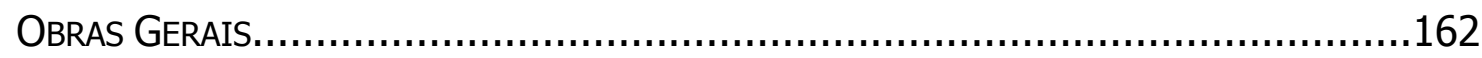




\section{APRESENTAÇÃO}

A proposta deste estudo é a de delinear uma concepção de inclusão que ultrapasse o âmbito das deficiências, não com a intenção de formular uma conceituação final, mas sim de contribuir para esse debate, o qual cada vez mais tem ganhado importância no cenário educacional e social brasileiro e mundial. A partir da discussão teórica sobre educação inclusiva, procurou-se ilustrar a discussão com uma proposta extensiva de intervenção junto a uma escola e suas repercussões entre os envolvidos, tendo como norte a vivência de um caminho coletivo, e esta como algo capaz de provocar uma revisão sistemática e intencional das concepções e práticas educativas na atualidade. $\mathrm{O}$ compartilhamento de uma trajetória conjunta segundo a qual pesquisadora e grupo de participantes trabalhassem em prol da reelaboração do conhecimento acumulado sobre a realidade em que estavam inseridos, pretendeu oportunizar a construção in loco de um espaço escolar democrático, tendo a ambiência inclusiva como perspectiva. O trabalho de campo relatado procurou sobretudo lastrear o percurso teórico desenvolvido, estabelecendo um caráter vivo à construção do conhecimento e não apenas visando a objetivos estritos de uma pesquisa em educação numa perspectiva tradicional.

O interesse pelo estudo das possíveis interfaces entre pesquisa, formação de educadores e construção de conhecimento teve início em 1998 quando de meu ingresso no curso de licenciatura na Faculdade de Educação da Universidade de São Paulo, o que viabilizou um estudo aprofundado de alguns documentos internacionais que abordam a questão da inclusão escolar na rede de ensino comum. Durante o curso, alguns questionamentos foram formulados, e foi justamente na busca de respostas a eles que surgiu a intenção de contribuir para a construção de um saber de relevância social. Se a proposta era discutir a questão da educação inclusiva, decidi que meu locus de atuação deveria ser a instituição escolar, uma vez que é aquela que melhor reflete as condições de inclusão educacional que marcam nossa sociedade. 
No período de elaboração deste trabalho, concomitante ao estudo teórico das questões educacionais, vários trabalhos em instituições escolares cuja perspectiva era uma atuação conjunta com os protagonistas escolares nas horas de trabalho coletivo foram iniciados. A participação no dia-a-dia escolar possibilitou a percepção de que o momento diagnóstico partilhado, singular em cada unidade, é de extrema relevância no que diz respeito ao estabelecimento de formas de intervenção que sejam de responsabilidade de todos. A organização desses espaços coletivos de trabalho no sentido de promover a sistematização, compreensão e diálogo entre os participantes não buscava apontar possíveis "culpados" pela situação atual da educação brasileira, mas expressava a intenção de construir conhecimento.

Ao mesmo tempo, participei das discussões que ocorriam no Conselho Regional de Psicologia - 6a região (CRP-SP), durante a gestão de 1999-2001, cujos assuntos principais eram a questão da educação especial/inclusiva e a reinserção da Psicologia no ensino médio, como meio de consolidar suas possíveis contribuições no cenário educacional.

A sistematização dessas discussões e do conhecimento produzido dentro do CRP-SP possibilitou a vivência de uma construção coletiva como forma de gerar uma responsabilidade do grupo na busca da transformação de uma realidade entendida como insatisfatória. O projeto político do Conselho consolidou a perspectiva de que a psicologia escolar/educacional não poderia criar métodos ou inventar diagnósticos para que os outros, ao seguirem à risca suas instruções, pudessem realizar uma educação de qualidade. Diferente disso, o trabalho caminhou para a defesa da educação de qualidade para todos como um compromisso social da Psicologia. Para tal, fizemos um movimento de entrada nos fóruns de discussão da educação para que lá, no centro dos debates, pudéssemos contribuir com nossas especificidades para construir uma escola não-seletiva, inclusiva e articulada aos interesses da maioria da população.

O Conselho Regional de Psicologia de São Paulo foi chamado para compor o Fedep/SP - Fórum Estadual em Defesa da Escola Pública de São Paulo - que se configura como uma articulação de entidades acadêmicas, sindicais, profissionais, estudantis e movimentos sociais, cujo principal objetivo é a defesa da educação 
pública, laica, gratuita, democrática e de qualidade para todos, em todos os níveis. Esse fórum foi lançado aos 18 de maio de 1990 e tem se constituído como espaço público, democrático e crítico de avaliação e proposição de políticas públicas para a educação.

A participação no III Coned - III Congresso Nacional de Educação ocorrido em Porto Alegre de 2 a 5 de dezembro de 1999 e promovido pelo Fórum Nacional em Defesa da Escola Pública - foi o marco definitivo para o estabelecimento da interface de uma entidade representativa da Psicologia com as da educação, também no nível nacional. Este movimento impulsionou o Conselho Federal de Psicologia a destacar a educação como uma de suas diretrizes de atuação.

Em São Paulo, a tarefa do Fórum Estadual em Defesa da Escola Pública Fedep/SP, nesse período, foi a de articular as entidades participantes em torno da construção do Plano Estadual de Educação da Sociedade Paulista nos mesmos moldes do Plano Nacional da Educação - Proposta da Sociedade Brasileira. As discussões ocorriam sempre segundo dois movimentos: debate interno com psicólogos que estavam trabalhando na educação, como professores de Psicologia ou como psicólogos escolares, e discussão nos Fóruns da Educação para agirmos de forma coerente, a partir de diretrizes coletivas.

Os resultados dessa interlocução podem ser explicitados, em primeiro lugar, na construção de um Plano Estadual de Educação, que contou com a contribuição de inúmeras entidades, direta ou indiretamente, o que consolidou o diálogo de acordo com o estabelecimento de consensos educacionais e o registro da importância que o Conselho teve como um dos articuladores e mediadores desse processo.

A militância permitiu-me inferir que toda a ação é política e deve ser coerente com o discurso, além de demonstrar o quão difícil é essa tarefa. Com o ingresso no programa de pós-graduação da Faculdade de Educação da Universidade de São Paulo em 2000, surgiu a oportunidade de elaborar um projeto direcionado ao processo de construção de conhecimento coletivo e sua coerência com as práticas cotidianas.

A partir da constatação de que, por vezes, a atuação do psicólogo produz exclusão escolar de crianças portadoras de deficiência ou não, iniciamos, no CRP-SP, 
a discussão sobre o acesso e a permanência na escola para todos, numa perspectiva ampliada da inclusão escolar. Aos poucos, fomos constatando que esse tema ainda não fazia parte do repertório dos psicólogos. Procuramos, então, como objetivo principal, levar à categoria as principais discussões trazidas pela "educação inclusiva", possibilitando uma redefinição do papel do psicólogo no contexto escolar/educacional. Nessa discussão, também, à medida que tomávamos contato com os documentos internacionais e a legislação nacional, intensamente debatida no Fedep, concluímos que não podíamos discutir essa questão apenas no interior do CRP/SP e que deveríamos procurar outros interlocutores.

Assim, iniciamos nossa participação no Fórum Permanente de Educação Especial organizado no Estado de São Paulo, cuja iniciativa partiu da Fundação Orsa, da Representação do MEC em São Paulo e de secretarias de educação de diversas prefeituras do Estado de São Paulo. Em abril de 2001, o nome do fórum foi alterado para Fórum Permanente de Educação Inclusiva, para marcar uma perspectiva de ação. No final de 2001, o fórum adotou uma carta de princípios norteadora e que expressa aquilo que se considera imprescindível para uma educação de qualidade. A perspectiva da inclusão adotada não mais pressupunha a fragmentação dos sistemas escolares (em "especial" e "comum"), mas a capacidade de educar na diversidade. Continuou sendo uma grande preocupação dos educadores envolvidos no fórum o atendimento aos alunos com deficiência ou necessidades educativas especiais, mas o mote do pensamento e da ação voltou-se para a modificação das escolas na medida da possibilidade de construção de um currículo flexível, de uma avaliação constante e da formação continuada dos professores para que estes possam acolher a todos como alunos co-partícipes da vida escolar.

Em 2002, participamos da organização do $4^{\circ}$ Coned - realizado de 23 a 26 de abril - no Anhembi em São Paulo, cujo tema era "Educação, Democracia e Qualidade Social - garantir direitos, verbas públicas e vida digna: uma outra educação é possível". Nesse congresso, o embate entre os dois projetos antagônicos para a educação ficou evidenciado pelo momento político de eleições gerais, e apontou para a necessidade de organização da sociedade para superação dos déficits sociais e educacionais do país. A riqueza das trocas durante a elaboração dos 
documentos que embasaram o Congresso fez com que eu me aproximasse definitivamente das questões da educação e colaborou para que eu configurasse meu objeto de estudo no trabalho do mestrado.

Além disso, considero importante a participação no Fórum Mundial de Educação, o qual começa a se configurar como espaço de articulação entre os movimentos em prol da educação para todos, no nível mundial. Durante as duas primeiras edições, o objetivo central foi o de elaborar uma Plataforma Mundial de Educação, contando com a participação de representantes da educação de vários países. Na edição nacional ocorrida em 2004, foi redigida a Carta do Fórum Mundial de Educação de São Paulo que se configurou como contribuição para a referida plataforma a ser finalizada em Porto Alegre no mês de julho desse mesmo ano.

Como já mencionado, no projeto do mestrado surgiu a intenção de levar a cabo essas experiências no espaço escolar, em conjunto com outros atores educacionais, na tentativa de produzir conhecimento e transformá-lo em algo relevante para além das estantes da biblioteca da universidade. 0 projeto foi reformulado e reconstruído à medida que a participação em espaços educacionais se ampliava. O início do programa de pós-graduação em 2000, mesmo ano em que eu era escolhida como coordenadora da Comissão de Educação do Conselho Regional de Psicologia de São Paulo e que se intensificava a participação nos fóruns descritos foi norteador de todo o trabalho.

Em virtude de todo dessa experiência teórica/prática fui convidada, no final de 2001, pela coordenação do setor de Educação Especial do Núcleo de Ação Pedagógica 12 da Secretaria Municipal de Educação de São Paulo, para assessorar os educadores da Escola Municipal de Ensino Fundamental Vianna Moog no que diz respeito ao enfrentamento dos novos desafios propostos a partir da perspectiva da "educação inclusiva" adotada pela atual gestão (2001-2004) da Prefeitura Municipal de São Paulo. Foi a partir deste lugar, por vezes incômodo, de especialista acadêmico, que se abriu um espaço possível de resgate de uma tríade indissociável: formação de professores, pesquisa da realidade educativa e construção de conhecimento.

O projeto começou a ser discutido com os professores em novembro de 2001 
para posterior implementação em 2002. O tema central apontado durante essa primeira etapa foi a discussão das bases de pensamento para as novas práticas educativas inseridas no contexto do paradigma social de respeito à diversidade e da inclusão de todos na escola.

A ação foi iniciada levando em consideração os espaços institucionais já existentes e os documentos já elaborados como consensos firmados pela unidade escolar. A construção de um conceito de educação inclusiva, a partir da leitura e discussão de textos de diferentes autores, estava relacionada com a realidade vivida nessa escola. 0 intuito era valorizar o espaço de trabalho coletivo no sentido de permitir que os professores pudessem compreender suas dificuldades e êxitos, trabalhando para desmistificar o paradigma da inclusão por meio do exercício da cooperação e da colaboração entre os participantes.

Esse processo, intrinsecamente pedagógico e claramente político, de diagnóstico e intervenção articulados buscou conhecer a realidade do ponto de vista dos que fazem a instituição escolar funcionar, tornando-se, ao mesmo tempo, processo e produto coletivos que têm um sentido local, sem perder de vista a importância do sentido geral.

A escola como lugar em que a teoria, a prática e as diretrizes governamentais se justapõem propicia, concomitantemente, a busca pela universalidade dos conhecimentos e consideração das especificidades locais, bem como o diálogo entre o conhecimento de questões clássicas, dos problemas contemporâneos, das pesquisas e das ações possíveis. Este aponta não para um treinamento, para a implementação de receitas educacionais, mas para um processo contínuo e coletivo com vistas a potencialização das ações dos protagonistas.

Diante dessa leitura, todo o sentido do trabalho foi o de buscar o aprendizado de novos repertórios de ação com o objetivo de ampliar os recursos, sem a preocupação de normalizar condutas. O estudo sobre determinado tema comum aos participantes, à luz do conhecimento acumulado na escola, na universidade e nos fóruns de debate, estimulou a construção de propostas coletivas para o enfrentamento das questões cotidianas.

A forma de apresentação do trabalho abrange, assim, esses diferentes 
momentos. No primeiro capítulo, enfocou-se a atualização do processo de democratização escolar centralizado em seus eixos principais: acesso, permanência e qualidade social. Inicia a análise uma breve retomada histórica dos vários momentos em que o Brasil teve a possibilidade de elaborar um plano nacional de educação, com ou sem efetivação de fato, até o momento atual. Além disso, os documentos internacionais dos quais o Brasil é signatário dão a idéia do quanto a perspectiva da educação para todos é, de fato, não apenas uma preocupação nacional, mas uma questão que está posta no nível mundial.

Em seguida, no segundo capítulo, buscou-se realizar um quadro preliminar da política educacional municipal no período da pesquisa, com ênfase em seus princípios fundamentais explicitados nas diretrizes educacionais e em suas formas de implementação.

A partir das proposições da educação para todos e da educação inclusiva formuladas de maneiras diversas nos documentos legais e oficiais apresentados, o terceiro capítulo pretendeu desenvolver o conceito de inclusão/exclusão numa concepção dialética, de modo a ampliar a análise da questão para além do âmbito educacional.

O capítulo seguinte apresenta a inclusão como perspectiva educacional originária da disputa pelo acesso ao sistema educacional comum de um grupo que tem sido historicamente objeto da educação especial. No sentido de contribuir para a construção de conhecimento nessa área, foram utilizadas obras de diversos autores, as quais possibilitaram leituras diversas no estabelecimento de um diálogo para a apreensão da proposta contemporânea do paradigma da inclusão.

O capítulo quinto descreve, na primeira parte, a pesquisa-ação como teoria metodológica diferenciada, focando quais as condições e as implicações de uma intervenção educacional extensiva e suas ações na perspectiva da construção coletiva de um projeto para a escola. A descrição do locus escolar por meio da caracterização da região e da unidade, em termos de recursos humanos e espaço físico, compõe, junto com a descrição da metodologia utilizada para a pesquisa, as subpartes deste tópico. A segunda parte do capítulo $\mathrm{V}$ descreve a intervenção propriamente dita, focalizando seus momentos mais significativos, sempre 
privilegiando o percurso, ou seja, o caráter processual da intervenção.

A instituição escolar como fonte inspiradora oportunizou a vivência da teoria no âmbito de uma história individual. O privilegiamento de técnicas qualitativas de análise metodológica, objetivadas pela pesquisa-ação, possibilitou não a elaboração de um modelo de atuação ou de uma receita de diretrizes pedagógicas, mas a construção de um caminho coletivo para o enfrentamento das questões cotidianas da escola à luz dos paradigmas sociais contemporâneos.

O último capítulo aponta alguns tópicos para debate. A intenção foi a de aproximar a realidade escolar e a discussão teórica apresentada sem a preocupação de criar categorias molares de análise, nem tampouco de propor algo que tivesse o caráter de proposta de salvação da educação pública, mas apenas de contribuir para diminuir a carência de estudos que abordam a realidade do ensino público no Brasil por meio de diálogo com aqueles que fazem cotidianamente a escola.

Como ressalta Paulo Freire, a educação não é transferência de conhecimento, pois não existe saber feito e acabado que possa ser captado e compreendido pelo educador e, em seguida, depositado nos educandos. A educação é ato dinâmico e permanente de conhecimento centrado na descoberta, análise e transformação da realidade pelos que a vivem. 


\section{Planos Nacionais de Educação:}

\section{A EduCAÇÃo COMO "QueSTÃo GovernamentaL"}

O presente capítulo tem como objetivo atualizar a questão do processo de democratização escolar levando em consideração seus três aspectos principais: acesso, permanência e qualidade social. Para tanto, analisa alguns momentos da história da educação brasileira em que houve marcadamente uma preocupação dos governos em elaborar projetos nacionais para a mesma. $O$ estabelecimento de tais planos e sua transformação posterior em lei foram considerados neste trabalho como quesitos para uma análise da perspectiva educacional a partir da segunda década do século $X X$.

Este capítulo trata ainda de alguns documentos internacionais dos quais o Brasil é signatário, como a Declaração Mundial de Educação para Todos, a de Salamanca, a de Nova Delhi, a de Dakar e a de Cochabamba, para elucidar suas influências na elaboração do arcabouço legislativo e normativo nacional.

O tema da educação brasileira como discussão nacional, ou seja, como debate que envolve toda a sociedade, remonta à década de 1920. Este é o momento em que, pela primeira vez em nossa história, surge a idéia de um plano de educação a ser estabelecido em lei para todo o país.

\footnotetext{
É verdade que a República, nos seus inícios, [...] foi pródiga em reformas, mas foi preciso esperar até a década de 20 para que, realmente, o debate educacional ganhasse um espaço social mais amplo. Foi nesse período que a questão educacional deixou de ser apenas tema de reflexão isolada e de discussões parlamentares para ser percebida como problema nacional, isto é, como problema afeto ao próprio destino da nacionalidade ${ }^{1}$.
}

Nesse período, a educação tinha como propósito a evolução da vida social. Há uma preocupação central em capacitar o trabalhador para que pudesse lidar com

1 José Mário Pires AZANHA, "Política e planos de educação no Brasil: alguns pontos para reflexão" Cadernos de Pesquisa n. 85, p. 71. 
a complexidade social que se amplia, e o governo federal vê na educação uma possibilidade de realizar essa tarefa.

A concentração das populações nas áreas urbanas, [...] a diferenciação das atividades econômicas e a valorização das funções de "peneiramento" da escola estão por trás da ampliação de vagas nos diferentes níveis do sistema escolar².

A educação brasileira continuou, como no período anterior à proclamação da República, baseada na separação entre governar/pensar e produzir/implementar. Nesse sentido, tanto a educação das elites como a educação para aqueles que deveriam realizar as tarefas sociais refletiam essa divisão. Os sinais de desenvolvimento urbano industrial estimularam o estabelecimento de um clima social que foi, em grande parte, responsável pela pressão para a ampliação de vagas nas escolas, revertidas, em sua maioria, para o ensino técnico com o intuito de "[...] fazer da civilização brasileira uma civilização eminentemente prática como práticas eram as mais modernas e avançadas nações do mundo contemporâneo" ${ }^{\prime 3}$.

Assim, há uma marca social que se traduz na prática técnica de implementação de uma perspectiva de nação mais avançada via educação. Todo o investimento na valorização do cidadão vislumbra a prosperidade do país e o investimento na educação objetiva, assim, a resolução de problemas sociais pontuais de forma rápida. De acordo com essa visão, há uma forte indicação de que o indivíduo, para ser inserido na sociedade, deve passar pelo processo de escolarização de modo que, de posse de novas técnicas de conhecimento e de uma postura social adequada, possa ingressar no mundo do trabalho e, assim, contribuir socialmente para a consolidação da sociedade brasileira.

É a partir da década de 1920 que a educação ganha status de questão nacional premente e a integração social passa pelos bancos escolares, apesar da existência de fatos anteriores que contribuíram para tal. Assim, problemas nacionais de educação brasileira são relativamente recentes e talvez nem mesmo sejam mais

2 Celso de Rui BEISIEGEL, Estado e educação popular: um estudo sobre a educação de adultos, p. 28. 3 Jorge NAGLE, Educação e sociedade no Brasil, 1920-1929, p. 366. 
antigos do que a República, dado que, antes disso, a educação era uma questão localizada, não nacional, e que, portanto, demandava soluções específicas ${ }^{4}$.

A Revolução de 1930 foi um desfecho para as crises políticas, sociais e econômicas que já podiam ser observadas em 1920, e teve uma influência importante no que se refere ao estabelecimento da educação como questão nacional.

Em 1932, um grupo de educadores lançou um documento ao povo e ao governo. Este, de redação de Fernando de Azevedo, ficou conhecido como o Manifesto dos Pioneiros da Educação Nova ${ }^{5}$, e contou com a assinatura de 25 homens e mulheres da elite intelectual brasileira. Esse documento esboçava um diagnóstico e uma proposta, ainda que incipiente, de plano nacional de educação.

Assentado o princípio do direito biológico de cada indivíduo à sua educação integral, cabe evidentemente ao estado a organização dos meios de o tornar efetivo, por um plano geral de educação ${ }^{6}$.

Sua grande repercussão motivou uma campanha nacional, chegando mesmo a ser incorporado à Constituição de 1934, a qual declarava como competência da União, por intermédio do Conselho Nacional de Educação, elaborar um plano nacional de educação para todos os níveis de ensino que deveria dispor de sugestões para o governo no sentido de apontar soluções para os problemas educacionais, bem como seu financiamento. Esse plano deveria ser remetido para aprovação pelo Poder Legislativo. Os artigos da Constituição de 1934 que tratam desse assunto são?:

Artigo 150 - Compete à União:

a) fixar o plano nacional de educação, compreensivo do ensino de todos os graus e ramos, comuns e especializados; e coordenar e fiscalizar a sua execução, em todo o território do País;

4 Cf. José Mário Pires AZANHA, op. cit., p 70.

5 Manifesto dos Pioneiros da Educação Nova, Revista Brasileira de Estudos Pedagógicos, n. 150, vol. 65, pp. 407-425.

6 José Mario Pires AZANHA, op. cit., p 72.

7 Grifos meus. 
b) determinar as condições de reconhecimento oficial dos estabelecimentos de ensino secundário e complementar deste e dos institutos de ensino superior, exercendo sobre eles a necessária fiscalização;

c) organizar e manter, nos Territórios, sistemas educativos apropriados aos mesmos;

d) manter no Distrito Federal ensino secundário e complementar deste, superior e universitário;

e) exercer ação supletiva, onde se faça necessária, por deficiência de iniciativa ou de recursos e estimular a obra educativa em todo o País, por meio de estudos, inquéritos, demonstrações e subvenções.

Parágrafo único - o plano nacional de educação constante de lei federal, nos termos dos artigos. 50, n. XIV, e 39, n. 8, letras a e e, só se poderá renovar em prazos determinados, e obedecerá às seguintes normas:

a) ensino primário integral gratuito e de freqüência obrigatória extensivo aos adultos;

b) tendência à gratuidade do ensino educativo ulterior ao primário, a fim de o tornar mais acessível;

c) liberdade de ensino em todos os graus e ramos, observadas as prescrições da legislação federal e da estadual;

d) ensino, nos estabelecimentos particulares, ministrado no idioma pátrio, salvo o de línguas estrangeiras;

e) limitação da matrícula à capacidade didática do estabelecimento e seleção por meio de provas de inteligência e aproveitamento, ou por processos objetivos apropriados à finalidade do curso;

f) reconhecimento dos estabelecimentos particulares de ensino somente quando assegurarem a seus professores a estabilidade, enquanto bem servirem, e uma remuneração condigna.

Artigo 151 - Compete aos Estados e ao Distrito Federal organizar e manter sistemas educativos nos territórios respectivos, respeitadas as diretrizes estabelecidas pela União.

Artigo 152 - Compete precipuamente ao Conselho Nacional de Educação, organizado na forma da lei, elaborar o plano nacional de educação para ser aprovado pelo Poder Legislativo e sugerir ao Governo as medidas que julgar necessárias para a melhor solução dos problemas educativos bem como a distribuição adequada dos fundos especiais.

Parágrafo único - Os Estados e o Distrito Federal, na forma das leis respectivas e para o exercício da sua competência na matéria, estabelecerão Conselhos de Educação com funções similares às do 
Conselho Nacional de Educação e departamentos autônomos de administração do ensino ${ }^{8}$.

Embora essa idéia não tenha saído do papel pelo seu caráter excessivamente centralizador, na Constituição Federal de 1946 fica expressa a idéia de um plano nacional de educação, identificado com o estabelecimento de diretrizes e bases para a educação nacional.

Somente com a Lei $n^{\circ} 4.024 / 1961$, nossa primeira Lei de Diretrizes e Bases da Educação Nacional - LDB, foram estabelecidas as primeiras coordenadas para a elaboração de um plano, apresentado em 1962, com objetivos e metas determinados para a educação em todo o país, o qual acabou não se constituindo em lei. Tratavase basicamente de um conjunto de metas qualitativas e quantitativas de iniciativa do Ministério da Educação e Cultura a serem alcançadas num prazo de oito anos. Tais metas, entretanto, geraram planos de governo que, pela primeira vez na nossa história, propuseram, entre outras orientações, que "até 1970, 100\% das crianças de sete a onze anos estivessem matriculadas na escola primária e $70 \%$ dos jovens no ensino secundário (antigo ginásio), vinculando-se recursos em Fundos Especiais para que se atingisse esse objetivo"rs.

Em 1967, ressurgiu a idéia de um plano nacional - Plano Educação para Todos - também proposta pelo Ministério da Educação e da Cultura, e que foi discutida mais amplamente com alguns setores da sociedade em quatro Encontros Nacionais de Planejamento. Essa iniciativa também não foi levada adiante, pois a proposta não se coadunava com as práticas de repasse de recursos adotadas pelos governos da época. A educação concretizava-se como algo diferente do direito do cidadão, ou seja, centrava-se na ordem da necessidade para o desenvolvimento do capitalismo e das idéias liberais de progresso. Essa idéia mantinha desvinculadas, no discurso do governo, as questões da educação e da formação, reforçando a idéia de capacitação originada no início dos anos de 1920. O acesso à educação se

8 Constituição da República dos Estados Unidos do Brasil de 1934.

9 Lei 4.024/61, Lei de Diretrizes e Bases da Educação Nacional (LDB). 
configurava como primordial para a efetivação de um plano de país desenvolvido e coadunado com o discurso externo de direito à educação cada vez mais difundido.

Houve várias iniciativas, como as de 1967, que se prolongaram por cerca de trinta anos. Para Moreira ${ }^{10}$, esse período caracterizou-se por uma série de planos parcialmente executados e abandonados, reflexo de que a educação não era prioritária para o governo. Uma justificativa poderia ser atribuída ao fato de que esta estivesse sendo vista ainda como meio para atingir-se uma certa meta de desenvolvimento nacional e não como um objeto que carecesse de estudos para uma discussão mais aprofundada de sua função social para além da capacitação de mãode-obra qualificada. As ações governamentais no âmbito da educação foram descontínuas e, em geral, centravam-se em sua função distributiva de recursos.

Segundo Azanha, a Lei de Diretrizes e Bases de 1971 (LDB 5692/71)

eliminou qualquer possibilidade de instituição de políticas e planos de educação como instrumentos efetivos de um desenvolvimento desejável da educação brasileira, pois [...] nada tem a ver com uma lei de diretrizes e bases concebida em termos de princípios gerais e consagrou novamente a idéia de plano como distribuição de recursos ${ }^{11}$.

De qualquer forma, pode-se notar uma estrutura educacional que não foi rompida até o final dos anos de 1980. A educação, então, era pensada por uma elite que dispunha tanto sobre o planejamento como sobre a tomada de decisões, via poder central da União. Todas as propostas, das mais "tradicionais" às mais "modernas", chegam aos Estados e Municípios para serem cumpridas, de certo modo uniformizando e padronizando estratégias educacionais. Pode-se mencionar ainda, com relação à gestão pública, que ações a cargo de Municípios e Estados não estavam articuladas em prol de um sistema educacional para o país. Assim, embora o objetivo, como citado, seja claro, qual seja, transformar o Brasil numa nação desenvolvida nos mesmos moldes de outras no mundo, "a falta de visão mais ampla impede que se apontem condições (estruturais) verdadeiramente impulsionadoras do

10 Cf. Roberto MOREIRA, Planejamento educacional no Brasil, pp. 185-207.

11 José Mário Pires AZANHA, op. cit., p. 74. 
progresso e de suas decorrências. Transplanta-se o produto, desligado do processo em relação ao qual é simples conseqüência final"121.

Somente cinqüenta anos depois, com a promulgação da Constituição Federal de 1988, retorna a idéia da necessidade de um plano nacional de educação que possa ser estabelecido com diretrizes e metas em longo prazo.

Segundo o artigo 241:

A lei estabelecerá o plano nacional de educação, de duração plurianual, visando articulação e ao desenvolvimento do ensino em seus diversos níveis e à integração das ações do poder público que conduzem à:

I - erradicação do analfabetismo;

II - universalização do atendimento escolar;

III - melhoria da qualidade de ensino;

IV - formação para o trabalho;

V- promoção humanística, científica e tecnológica do país ${ }^{13}$.

Nota-se que há um fortalecimento do discurso de que um país desenvolvido preocupa-se com a educação de seus cidadãos mesclando o incremento tecnológico com uma formação mais humanista. Percebe-se também, para além do assinalamento da universalização do acesso à educação escolar, a preocupação com a qualidade da mesma.

Durante o governo do presidente Fernando Henrique Cardoso, a aprovação da Lei $n^{0}$ 9.394/1996 - Lei de Diretrizes e Bases da Educação Nacional - estabelece no Título IX - Das Disposições Transitórias:

\footnotetext{
Artigo 87:

É instituída a Década da Educação, a iniciar-se um ano a partir da publicação desta lei.

I - A União, no prazo de um ano a partir da publicação desta lei, encaminhará, ao Congresso Nacional o Plano Nacional de Educação, com diretrizes e metas para os dez anos seguintes, em sintonia com a Declaração Mundial sobre Educação para Todos ${ }^{14}$.
}

12 Jorge NAGLE, op. cit,, p. 435.

13 Constituição da República Federativa do Brasil de 1988.

14 Lei 9.394/96, Lei de Diretrizes e Bases da Educação Nacional (LDB). 
Além disso, a LDB, em seu artigo $9^{\circ}$, explicita claramente que:

A União incumbir-se-á de:

I - elaborar o Plano Nacional de Educação, em colaboração com os Estados, o Distrito Federal e os Municípios;

II - organizar, manter e desenvolver os órgãos e instituições oficiais do sistema federal de ensino e territórios ${ }^{15}$.

Neste momento, cabe realizar um breve histórico do movimento da sociedade civil organizada no Fórum Nacional em Defesa da Escola Pública em prol da participação popular na elaboração e no referendo tanto da Lei de Diretrizes e Bases da Educação Nacional como do Plano Nacional de Educação - Proposta da Sociedade Brasileira.

A Carta de Porto Alegre, documento elaborado no final do terceiro Congresso Nacional de Educação (Coned) descreve de forma clara e concisa os princípios que nortearam as discussões encampadas pelos representantes das entidades que compunham o fórum - mais da metade representando os trabalhadores $e$ trabalhadoras em educação nacional - afirmando a educação como direito de todos e dever do Estado. Seus pontos principais delineiam os contextos social, econômico e político brasileiro a partir do aprofundamento das idéias liberais, chamadas de neoliberalismo, que, via globalização pretensamente inexorável, aprofundam suas marcas nas políticas públicas. Aponta a ingerência de organismos internacionais, a exemplo do Banco Mundial, que estabelecem tanto a estrutura como a função dos vários níveis da educação - do infantil à pós-graduação. Destaca a posição do governo central de reconhecer algumas mazelas educacionais como "naturais", aprofundando e dando seqüência à política dos organismos internacionais que vinham fazendo eco no país sob o discurso do caminho para o desenvolvimento e modernidade.

O contexto social, econômico e político brasileiro é o do neoliberalismo, que 
tenta, via globalização pretensamente inexorável imprimir marca indelével nas políticas públicas, entre elas a educação. Tais políticas são induzidas por organismos internacionais impostas como acima de quaisquer suspeitas ${ }^{16}$.

Pode-se observar que o discurso predominante no período dos governos militares (1964-1986), época de restrições dos direitos civis e, portanto, da democracia, continuava, de certa forma, hegemônico. O privilegiamento da racionalidade técnica como fator crucial para o progresso nacional era ainda pano de fundo para a crescente desresponsabilidade do Estado, que partia claramente por uma opção política de privatização generalizada, inclusive na educação, acarretando uma crescente flexibilização das relações de trabalho e uma exclusão social de grandes parcelas da sociedade.

A partir dessa avaliação conjuntural, as entidades que integravam o Fórum Nacional em Defesa da Escola Pública empenharam-se na construção do projeto de uma Lei de Diretrizes e Bases, que foi encaminhado ao Congresso Nacional como PL n. $1.258 / 88$.

Deve-se ressaltar, entretanto, que, embora a análise contextual fosse bastante inóspita, a possibilidade de que as entidades pudessem reunir-se em torno da elaboração de uma proposta para a educação nacional, fato que não seria possível no período da ditadura militar, era, de qualquer forma, um avanço, pelo menos no que diz respeito ao processo de redemocratização nacional.

O projeto de lei para uma Lei de Diretrizes e Bases para a Educação Nacional representativo da sociedade brasileira foi substituído por outro no Senado, elaborado à revelia da sociedade e aprovado no Congresso Nacional em 1996. Trata-se da Lei de Diretrizes e Bases para a Educação Nacional em vigor - Lei 9394/96.

Esse documento contém avanços e recuos em relação aos documentos anteriores. Nele, é interessante notar que o Estado se coloca mais fortemente como distribuidor de verbas para os Estados e Municípios, e deixa a função supletiva para quando for estritamente necessário. Além disso, parece centralizar sua ação no estabelecimento de metas e na avaliação, deixando, desta forma, os entes federados 
com a incumbência de estabelecer políticas educacionais que se adaptem ao modelo proposto, pois é a partir dele que estes serão avaliados no sentido de receber mais ou menos recursos financeiros. Pode-se dizer que essa lei estabeleceu um vínculo forte da educação com o mercado, ou seja, as diretrizes educacionais, estabelecidas pela União, devem ser seguidas como condição para a obtenção de recursos. A lógica de se aliar normas à possibilidade de financiamento é estritamente mercantil. A descentralização, seguindo-se essa linha, ocorre muito mais para isentar a União de suas responsabilidades com a educação popular. Além disso, instaura uma disputa entre os níveis e modalidades de ensino com a criação de um fundo não para a captação de novos recursos, mas para a subvinculação dos mesmos. Esse fundo, Fundo de Manutenção e Desenvolvimento do Ensino Fundamental e de Valorização do Magistério (Fundef), poderia apenas ser utilizado com o ensino fundamental, inviabilizando, por vezes, que os Estados e Municípios disponham dos recursos para atender as demandas locais (Emenda Constitucional 14/96) ${ }^{17}$.

Posto isto, voltemos à retrospectiva histórica do Fórum Nacional em Defesa da Escola Pública. As entidades reunidas nesse espaço passaram, com a aprovação da LDB, a denunciar a consolidação dos princípios econômicos acima dos interesses da construção de uma educação de qualidade social apontados na Lei de Diretrizes e Bases da Educação Nacional (Lei n. 9.394/96) e na legislação correlata, como forma de dar continuidade a políticas educacionais excludentes e, portanto, contrárias aos interesses da maioria da população brasileira. Esse conjunto de ações formou a proposta do I Congresso Nacional de Educação (I Coned - Belo Horizonte/1996) que estabeleceu como objetivo central organizar a intervenção nos processos de elaboração e tramitação da LDB e a sistematização das diretrizes educacionais para a

17 No artigo 60 inseriu-se ainda que "Nos dez primeiros anos da promulgação desta emenda, os Estados, o Distrito Federal e os Municípios destinarão não menos que sessenta por cento dos recursos a que se refere o caput do artigo 212 da Constituição Federal à manutenção e ao desenvolvimento do ensino fundamental, com o objetivo de assegurar a universalização de seu atendimento e a remuneração condigna do magistério.

I - A distribuição de responsabilidades e recursos entre os Estados e seus Municípios a ser concretizada como parte dos recursos definidos neste artigo, na forma do disposto no artigo 211 da Constituição Federal, é assegurada mediante a criação, no âmbito de cada Estado e do Distrito Federal, de um Fundo de Manutenção e Desenvolvimento do Ensino Fundamental e de valorização do magistério, de natureza contábil". 
elaboração de um Plano Nacional de Educação alternativo. Com base nessas diretrizes e mobilizadas em resistência à promulgação da Lei de Diretrizes e Bases, as entidades do Fórum Nacional em Defesa da Escola Pública promoveram, em todo o território nacional, numerosas atividades que antecederam e garantiram a discussão das diretrizes para o Plano Nacional de Educação alternativo.

A realização do II Coned (Belo Horizonte/1997) objetivou a sistematização destes encontros regionais/estaduais, o que possibilitou a construção do Plano Nacional de Educação - Proposta da Sociedade Brasileira, nome dado ao plano nacional alternativo. Passou a ser a principal tarefa do Fórum Nacional em Defesa da Escola Pública o fortalecimento desse documento, sua divulgação e defesa.

Adiantando-se ao governo, as entidades nacionais transformaram essa sistematização da utopia educacional num instrumento de intervenção política que garantisse a concretização de uma educação para a cidadania, reafirmando-a como direito de todos e dever do Estado. Este PNE ganhou forma de Projeto de Lei - PL n. 4.155/98 - no Congresso Nacional. A estratégia de construção democrática desse PNE obrigou o governo a produzir de forma rápida o PNE - Proposta do Executivo ao Congresso Nacional (PNE/MEC), que revelou as reais concepções e diretrizes da política educacional dos setores hegemônicos representados no/pelo governo. A proposta de Plano Nacional do Ministério da Educação (PNE/MEC) teve poucos interlocutores e foi elaborada por técnicos do Ministério, sem ser realizada qualquer discussão com outros setores da sociedade.

O PNE/MEC, por ter sido encaminhado depois do PNE - Proposta da Sociedade Brasileira, teve que ser apensado a este com a denominação de Projeto de Lei n. 4.173/98. Porém, de apensado ao PNE - Proposta da Sociedade Brasileira, o PNE/MEC tornou-se, pelo substitutivo do relator da Comissão de Educação da Câmara Federal, Deputado Nelson Marchezan (PSDB/RS), de fato, no projeto de lei que foi aprovado. As partes introdutórias do ideário do PNE - Proposta da Sociedade Brasileira foram mantidas. As metas fixadas, porém, foram as do PNE/MEC.

De qualquer forma, o Plano Nacional de Educação - Proposta da Sociedade Brasileira construído pelos setores organizados da sociedade civil (entidades acadêmicas, científicas, sindicais e estudantis, de âmbito nacional e local), 
apresentado ao Congresso Nacional em 3 de dezembro de 1997, transformado no PL $\mathrm{n}^{0} 4.155$ em fevereiro de 1998, e depois recortado para atender às metas do PNE/MEC, inaugura uma forma de participação mais democrática na construção de planos educacionais no país.

Além disso, os setores da sociedade civil organizada, mergulhados nessa discussão, inauguram verdadeiramente uma articulação de esforços para mobilizar os governos municipais e estaduais com o intuito de criar planos de educação que, a partir de uma análise estrutural, apontassem diretrizes e metas para a educação brasileira.

O III Coned, que ocorreu em dezembro de 1999 na cidade de Porto Alegre, refletiu essas preocupações e, por se realizar justamente no momento em que tramitava na Câmara dos Deputados o projeto de lei 4173/98 apensado ao 4155/98, estabeleceu como meta um triplo caráter: o de informação e análise voltado para o conhecimento de experiências, trabalhos e pesquisas de cunho inclusivo, desenvolvidos no país; o de constatação e denúncia voltado para a avaliação das políticas educacionais em vigor; e o de definição e articulação com o objetivo de apontar políticas para garantir o direito de todos à educação.

Após três anos de tramitação, o presidente Fernando Henrique Cardoso sancionou a Lei $\mathrm{n}^{0} 10.172$, de janeiro de 2001, que estabeleceu o Plano Nacional de Educação para uma década e determinou que, com base neste, os Estados, o Distrito Federal e os Municípios elaborassem Planos Estaduais e Municipais de Educação.

A quarta edição do Congresso Nacional de Educação, $4^{\circ}$ Coned $^{18}$, ocorrida na cidade de São Paulo em abril de 2002, além de rediscutir politicamente o Plano Nacional de Educação - Proposta da Sociedade Brasileira e atualizar seus dados quantitativos, teve como objetivo maior garantir a continuidade do processo de construção coletiva e democrática de um projeto de educação para o país. Adotou como princípio

18 A numeração dos três primeiros Coned foi estabelecida com algarismos romanos, enquanto os subseqüentes foram numerados com algarismos arábicos. 
consolidar o que já foi realizado até agora e retomar a iniciativa política, por meio de uma plataforma de lutas que inclua a revogação da Lei $n$. 10.172/2001 (PNE) e a construção de Planos Estaduais de Educação (PEE) e Planos Municipais de Educação (PME), tendo como referência o Plano Nacional de Educação: Proposta da Sociedade Brasileira ${ }^{19}$.

Nas plenárias finais, dentre outras propostas, foi encaminhada a necessidade de (re)articulação dos Fóruns Estaduais e Municipais de Educação existentes e de organização onde não existissem, para a construção de Planos de Educação no âmbito dos Estados e dos Municípios.

A estrutura disposta em mesas de debates, painéis e conferências objetivou politizar e difundir temas que, de certa forma, poderiam subsidiar os participantes na elaboração de ações concretas a curto, médio e longo prazos. Os trabalhos apresentados divulgaram vários projetos que, de algum modo, combatem as ações governamentais de exclusão e sucateamento da educação, mostrando, na prática, algumas possibilidades de mobilização. Como documentos finais, foram ainda elaboradas algumas alterações no PNE - Proposta da Sociedade Brasileira, um plano de lutas e uma agenda política.

Durante essas quase duas décadas, o Fórum Nacional em Defesa da Escola Pública tem reunido contribuições importantes de diversos movimentos, como referenda o próprio Plano Nacional de Educação (lei 10.172/01), que em seu trecho introdutório destaca:

A construção deste plano atendeu aos compromissos assumidos pelo Fórum Nacional em Defesa da Escola Pública, desde sua participação nos trabalhos da Assembléia Nacional Constituinte, consolidou os trabalhos do I e II Congressos Nacionais de Educação - Coned e sistematizou as contribuições advindas de diferentes segmentos da sociedade civil $^{20}$.

Na justificativa, o deputado-autor destaca a importância desse documentoreferência que "contempla dimensões e problemas sociais, culturais, políticos e

19 Fórum Nacional em Defesa da Escola Pública, Cadernos do 40 Coned, p. 11.

20 Lei 10.172/01 Plano Nacional de Educação, introdução. 
educacionais brasileiros, embasado nas lutas e proposições daqueles que defendem uma sociedade mais justa e igualitária"21.

Seu braço paulista, o Fórum Estadual em Defesa da Escola Pública Fedep/SP -, cujo lançamento deu-se aos 18 de maio de 1990 na Assembléia Legislativa de São Paulo, foi rearticulado, passando a direcionar seus esforços para contribuir na construção do Plano Estadual de Educação para São Paulo.

O Fedep/SP constitui-se num espaço coletivo e democrático de discussão que congrega entidades acadêmicas, sindicais, profissionais, estudantis e movimentos sociais que adotam uma Carta de Princípios (reproduzida abaixo) e têm como objetivo comum: a defesa da educação pública, gratuita, democrática, laica e de boa qualidade para todos, em todos os níveis.

1. educação fundada na solidariedade, no diálogo, na honestidade, no respeito às diferenças humanas e culturais, na inclusão e justiça social, enfim, nos valores humanistas e na ética política;

2. gestão democrática em todas as instâncias dos sistemas de ensino e nas unidades escolares, ou seja, com participação democrática e controle social;

3. financiamento adequado às demandas educacionais pelo Poder Público;

4. valorização dos profissionais em Educação, por meio de ingresso por concursos públicos, planos de carreira, piso salarial digno e oportunidades sistemáticas de formação continuada;

5. sistema Estadual de Educação igualmente planejado quanto à elaboração, implementação e avaliação de modo a assegurar os interesses da sociedade;

6. educação escolar como instrumento fundamental de desenvolvimento individual, social, cultural, político e econômico do país, para garantir ao seu povo os direitos básicos da cidadania e ampliar nossas prerrogativas de soberania nacional;

7. autonomia didático-científica, assegurando o direito de cada instituição escolar construir seu Projeto Político Pedagógico;

8. indissociabilidade entre ensino-pesquisa-extensão no ensino superior ${ }^{22}$.

21 Idem.

22 Fórum Estadual em Defesa da Escola Pública - Carta de Princípios do Fedep/SP. 
Tendo como referência o documento Plano Nacional de Educação - Proposta da Sociedade Brasileira, os participantes do Fedep/SP deflagraram um processo de discussão de diretrizes para a elaboração do Plano Estadual de Educação - Proposta da Sociedade Paulista.

Os seminários temáticos ${ }^{23}$, organizados pelo Fedep/SP, tiveram a finalidade de promover o debate e aprofundar a reflexão a respeito das políticas públicas para a educação, além de estimular o envolvimento de mais pessoas e entidades na construção do referido plano.

Para garantir a participação de todos os segmentos sociais na construção de um Plano Estadual de Educação democrático e emancipador, foram organizadas, ainda, Plenárias Regionais Temáticas ${ }^{24}$ em várias cidades do interior e litoral paulista, cujos participantes - oriundos de diferentes setores da sociedade civil - discutiram e explicitaram o diagnóstico, as diretrizes, os objetivos e as prioridades para a educação no Estado de São Paulo.

O Plano Estadual de Educação - Proposta da Sociedade Paulista (PEE), lançado aos 14 de outubro de 2003 e - como apontado na introdução de sua edição pela Adusp - Associação dos Docentes da Universidade de São Paulo, revisada em 20 de outubro do mesmo ano - propõe-se a ser um instrumento definido em razão da política educacional, cujo principal objetivo é atender às necessidades educacionais da maioria da população na defesa de princípios éticos voltados para a busca de igualdade e justiça social no sentido de mudar o modelo social vigente, tornando-o de fato democrático. O Plano aponta que, para tal transformação, há a precisão de um projeto de desenvolvimento do Estado de São Paulo que tenha como centro, em suas dimensões econômica, social, cultural e política, o aperfeiçoamento e a dignificação do homem, não do mercado.

23 Foram, no total, três encontros. Um seminário foi realizado na sede central da Apeoesp - Sindicato dos Professores do Ensino oficial do Estado de São Paulo cujo tema foi a "Formação de Professores"; o outro foi promovido na Unesp - Universidade Estadual Paulista, em São Paulo, com o título "Planos de Educação: Nacional, Estadual e Municipal"; e, o último ocorreu na Assembléia Legislativa do Estado de São Paulo que teve com o eixo de discussão "O Financiamento da Educação".

24 Os Municípios de Marília, Bebedouro, Santos, Salto, Taubaté e Piracicaba acolheram as plenárias, pois, de certa forma, atuam como pólos aglutinadores das cidades vizinhas. 
É no quadro dessa perspectiva de sobrevivência e desenvolvimento (sobretudo dos excluídos) que se situa o presente Plano Estadual de Educação a ser articulado com as políticas já indicadas e a construção de um quadro cultural a ser apropriado pelo conjunto da sociedade paulista, bem como construído também por ela a partir das identidades simbólicas e materiais existentes ${ }^{25}$.

O Plano situa a educação escolar como um instrumento estratégico para o desenvolvimento econômico, social, cultural e político do Estado e de seu povo, e para a garantia dos direitos básicos de cidadania e da liberdade pessoal, concebendo a escolarização como um direito do cidadão e um patrimônio da sociedade. Assim, sua administração, planejamento e execução devem se dar da forma mais ampla e democrática possível, abrindo espaço para todas as concepções, culturas, etnias, princípios e orientações, respeitando os conteúdos expressos na legislação nacional e estadual.

Pode-se perceber que há, claramente, o delineamento de uma perspectiva diferente dos discursos dos governos vistos até agora. Se nesse documento observase que a educação é essencial para o desenvolvimento do país, o processo de como essa construção pode ser efetivado é inverso. Ou seja, o plano aponta que é por meio de discussões entre os cidadãos que o seu planejamento e a sua execução devem ser formulados, num movimento de baixo para cima. Além disso, postula que a educação é

\begin{abstract}
Um instrumento de formação ampla, de luta pelos direitos da cidadania e da emancipação social, preparando as pessoas e a sociedade para a responsabilidade de construir, coletivamente, um projeto de inclusão e de qualidade social para o Estado de São Paulo fundamentado, em especial, nos artigos 06, 205 e 208 da Constituição Federal de 1988, que concebem a educação como direito social ${ }^{26}$.
\end{abstract}

Ao analisar cada artigo acima citado, verifica-se que o $6^{\circ}$ determina que a educação, a saúde, o trabalho, o lazer, a segurança, a previdência social, a proteção

25 Fórum Estadual em Defesa da Escola Pública (Fedep/SP), Plano Estadual de Educação - Proposta da Sociedade Paulista, p. 14.

26 Idem, ibidem. 
à maternidade e à infância, a assistência aos desamparados são direitos sociais. 0 artigo $205^{\circ}$, por sua vez, afirma a educação como direito de todos e dever do Estado e da família, devendo ser promovida e incentivada com a colaboração da sociedade, visando ao pleno desenvolvimento da pessoa, seu preparo para o exercício da cidadania e sua qualificação para o trabalho. E, finalmente, o Artigo $208^{\circ}$ aponta que

O dever do Estado com a educação será efetivado mediante a garantia de:

I - ensino fundamental, obrigatório e gratuito, assegurará, inclusive, sua oferta gratuita para todos os que a ele não tiveram acesso na idade própria;

II - Progressiva universalização do ensino médio gratuito;

III - atendimento educacional especializado aos portadores de deficiência, preferencialmente na rede regular de ensino;

IV - atendimento em creche e pré-escola às crianças de 0 a 6 anos de idade;

V - acesso aos níveis mais elevados do ensino, da pesquisa e da criação artística, segundo a capacidade de cada um;

VI - oferta de ensino noturno regular, adequado às condições do educando;

VII - atendimento ao educando, no ensino fundamental, através de programas suplementares de material didático-escolar; transporte, alimentação, e assistência à saúde:

$\S 10$ acesso ao ensino obrigatório e gratuito é direito público subjetivo;

$\S 2^{\circ} \mathrm{O}$ não oferecimento do ensino obrigatório pelo poder público, ou sua oferta irregular, importa em responsabilidade da autoridade competente;

$\S 3^{\circ}$ Compete ao poder público recensear os educandos do ensino fundamental, fazer-Ihes a chamada e zelar, junto aos pais ou responsáveis, pela freqüência à escola ${ }^{27}$.

O projeto de inclusão mencionado se estabelece a partir de ações do Poder Público com o intuito de assegurar a educação para todos em sua forma mais ampla: o acesso e a permanência no ensino obrigatório, gratuito e de boa qualidade.

Ele define como sinônimos a boa qualidade e a qualidade social, caracterizando-as como a busca de uma educação escolar com padrões de excelência e adequação aos interesses da maioria da população, no conjunto da sociedade. De acordo com essa perspectiva, são valores fundamentais a

27 Constituição da República Federativa do Brasil de 1988. 
solidariedade, a autonomia, a liberdade e a cidadania para o desenvolvimento da consciência moral e de uma forma de agir segundo padrões éticos.

A educação de qualidade social tem como conseqüência a inclusão social, por meio da qual todos os brasileiros se tornem aptos ao questionamento, à problematização, à tomada de decisões, buscando as ações coletivas possíveis e necessárias ao encaminhamento dos problemas de cada um e da comunidade onde vivem e trabalham. Incluir significa possibilitar o acesso e a permanência, com sucesso, nas escolas, significa gerir democraticamente a educação, incorporando a sociedade na definição das prioridades das políticas sociais, em especial, a de educação ${ }^{28}$.

O documento preocupa-se ainda em descrever o que se entende por cidadania, possibilitando ao leitor perceber que as idéias dispostas ao longo do texto não se coadunam a uma perspectiva mercadológica da educação. $O$ projeto de inclusão proposto estabelece que a escola deve promover uma formação ampla voltada para o desenvolvimento de valores e atributos inerentes à idéia de cidadania, o que permitiria uma intervenção ativa, crítica e construtora de cultura, da história e da sociedade em que estão inseridos seus alunos, professores etc, privilegiando todas as dimensões de suas relações com o mundo. O plano opõe-se a soluções globalizantes para a educação que, com 0 intuito de formar indivíduos pretensamente consumidores e competitivos, uniformizam e despotencializam as relações sociais.

Nessa dimensão, a escola se redefine como um espaço democrático de elaboração de valores, de tolerância e respeito às diferenças, de produção, recriação e disseminação de conhecimento e de convivência humana e social, cultural e política, levando sempre em consideração a realidade das relações sociais e de trabalho ${ }^{29}$.

A cidadania é entendida como algo construído e constantemente reelaborado na formação, forjada na busca incessante da inclusão de todos, contemplando os diversos setores sociais historicamente excluídos, sempre dentro de uma dada

28 Fórum Estadual em Defesa da Escola Pública (Fedep/SP), Plano Estadual de Educação - Proposta da Sociedade Paulista, p. 15.

29 Idem, ibidem. 
realidade social. Diferencia-se, portanto, de um conceito homogeneizador e esvaziado, de significado único e relacionado ao mercado.

Nesta concepção, a escola, garantida e financiada pelo Estado, é construída por alunos, pais, professores, servidores técnico-pedagógicos, técnicoadministrativos e de apoio, como o espaço público de troca e elaboração de experiências, tendo em vista a articulação das ações possíveis e necessárias à solução dos problemas de cada comunidade e do desenvolvimento de todos ${ }^{30}$.

Outro conceito importante definido pelo plano é o da gestão democrática. Segundo seus autores, é justamente essa gestão, tanto do sistema como das escolas, que pode possibilitar a democratização do acesso e a permanência das crianças e jovens nas escolas, a valorização do profissional da educação e a educação de boa qualidade para todos.

A escola pública pertence ao público, que decide sobre o projeto pedagógico com o qual todos se comprometem, desempenhando seu papel com competência e responsabilidade. Essa gestão depende da intervenção dos setores organizados da sociedade e do aprofundamento da cidadania ${ }^{31}$.

Essa visão foi o mote para que o Plano Estadual de Educação - Proposta da Sociedade Paulista (PEE) fosse discutido ativamente por todos os interessados, por meio de seus representantes. A idéia que permeou a elaboração desse plano surgiu do entendimento entre os autores e os signatários do mesmo de que tal iniciativa não deveria estar restrita aos gabinetes dos poderes Executivo e/ou Legislativo executores legais dessa tarefa especificada constitucionalmente - mas possibilitar a consulta aos setores sociais envolvidos com a educação. O processo de discussão aberta para elaborar princípios, diretrizes, prioridades, metas e estratégias de ação pretendeu possibilitar a união entre concepção e execução, ou seja, de alguma

30 Fórum Estadual em Defesa da Escola Pública (Fedep/SP), Plano Estadual de Educação - Proposta da Sociedade Paulista, p. 15.

31 Ibid., pp. 15 e 16. 
forma, possibilitar que aqueles que efetivamente "fazem" a educação possam ser contemplados quando da elaboração de um projeto para a mesma.

Conquanto inserida na Constituição Federal de 1988 (CF/88, Artigo 206, IV) ${ }^{32}$, o princípio da gestão democrática na área da educação restringe-se a uma normatização. Embora deva se destacar que se trata de um avanço, tal preocupação ser mencionada num documento do porte da Constituição e, que, portanto, dela não possa ser retirado com facilidade, ele, para além de seu aspecto legal, relaciona-se como estratégia do processo de superação do autoritarismo, individualismo e das desigualdades sociais, com qualidade e eficiência, em contraposição à gestão exercida a serviço de interesses e objetivos particulares. Sendo assim, a gestão do Sistema Estadual de Educação, em todas as suas instâncias, deve ter como preceito básico a democracia objetivada: no caráter público e gratuito da educação, na inserção social, nas práticas participativas, na descentralização do poder, na socialização dos conhecimentos e das decisões.

\begin{abstract}
A fundamentação dessa gestão está, pois, na constituição de um espaço público de direito, que deve promover condições de igualdade, garantir estrutura material para promover um serviço educacional de boa qualidade, criar um ambiente de trabalho coletivo que vise à superação de um sistema educacional fragmentado, seletivo e excludente, e, ao mesmo tempo, que possibilite a inter-relação desse sistema com o modo de produção e distribuição de riqueza, com a estruturação da sociedade, com a organização política, com a definição de papéis do Poder Público, com as teorias do conhecimento, as ciências, as artes e as culturas ${ }^{33}$.
\end{abstract}

No caminho desde o Sistema Nacional de Educação ${ }^{34}$ até a sala de aula, o eixo mobilizador são as atitudes democráticas das pessoas em todos esses espaços de intervenção. A centralidade do sujeito, nessa perspectiva, realiza-se justamente quando, ao se elaborar e se executar o planejamento educacional, o movimento

$32 \mathrm{O}$ artigo 206 diz que "O ensino será ministrado com base nos seguintes princípios [...] §VI - gestão democrática do ensino público, na forma da lei".

33 Fórum Estadual em Defesa da Escola Pública (Fedep/SP), Plano Estadual de Educação - Proposta da Sociedade Paulista, p. 19.

34 Proposta histórica do Fórum Nacional em Defesa da Escola Pública detalhada no Caderno do 50 Congresso Nacional de Educação realizado entre 2 e 5 de maio de 2004 em Recife (PE) no texto referente ao Eixo Temático 1 - "Organização e Avaliação da Educação Nacional". 
dialético de relações que se estabelecem entre a instituição educacional e a sociedade e entre os que estão no cotidiano escolar permeia o processo, de tal forma que possibilite aos participantes a utilização de mecanismos de construção e de implementação da qualidade social, contribuindo para o respeito às identidades sociais diferenciadas e para a democratização das instituições.

As experiências democráticas que concorrem para o aperfeiçoamento dessa gestão são as que reforçam a participação de todos os segmentos constitutivos da comunidade escolar, norteiam-se pela construção de projetos político-pedagógicos participativos e convivem com os colegiados e as representações dos grupos sociais existentes no interior das instituições escolares ${ }^{35}$.

Desse modo, enquanto os setores organizados, notadamente os da educação, têm se preocupado em, de forma coletiva, apontar um caminho para que a educação nacional consiga ser efetivada como um direito de todos apostando, para tal, na via da construção da cidadania para o desenvolvimento do país, os documentos do governo têm delineado uma série de regras a serem executadas, privilegiando o caminho da aquisição de conhecimentos técnicos e de novas tecnologias para que o ingresso de nosso país no grupo de países "desenvolvidos" seja atingido a partir da capacitação da mão-de-obra nacional.

Todavia, apesar de vários governos mais ou menos autoritários tentarem dar respostas rápidas e conjunturais, descrevendo a educação como estratégia desenvolvimentista, o que uma análise, ainda que superficial, mostra, é que nosso Índice de Desenvolvimento Humano (IDH) e nossa taxa de analfabetismo (ver tabela na próxima página $)^{36}$, quando comparados com outros países, são preocupantes. $\mathrm{A}$ partir dela pode-se inferir que, a despeito de estarmos na época das novas tecnologias, da sociedade globalizada e da informação em tempo real, o Brasil continua a ocupar uma posição inferiorizada, tal a gravidade do déficit educacional acumulado ao longo de nossa história.

35 Fórum Estadual em Defesa da Escola Pública (Fedep/SP), Plano Estadual de Educação - Proposta da Sociedade Paulista, p. 20.

36 Tabela publicada no Mapa do Analfabetismo no Brasil, editado pelo Ministério da Educação em maio de 2003. 


\begin{tabular}{|c|c|c|c|}
\hline \multicolumn{4}{|c|}{$\begin{array}{l}\text { Índice de Desenvolvimento Humano e Taxa de Analfabetismo } \\
\text { População de } 15 \text { anos ou mais - Países Selecionados }\end{array}$} \\
\hline País & IDH & Posição & $\begin{array}{c}\text { Taxa de } \\
\text { Analfabetismo (\%) }\end{array}$ \\
\hline Noruega & 0,942 & $1^{\circ}$ & 0,0 \\
\hline Austrália & 0,939 & $5^{\circ}$ & 0,0 \\
\hline Áustria & 0,926 & $15^{\circ}$ & 0,0 \\
\hline Espanha & 0,913 & $21^{\circ}$ & 0,0 \\
\hline Portugal & 0,880 & $28^{\circ}$ & 7,6 \\
\hline Argentina & 0,844 & $34^{\circ}$ & 3,2 \\
\hline Chile & 0,831 & $38^{\circ}$ & 4,2 \\
\hline Costa Rica & 0,820 & $43^{\circ}$ & 4,4 \\
\hline Trinidad e Tobago & 0,805 & $50^{\circ}$ & 1,7 \\
\hline México & 0,796 & $54^{\circ}$ & 8,8 \\
\hline Colômbia & 0,772 & $68^{\circ}$ & 8,4 \\
\hline Brasil & 0,757 & $73^{\circ}$ & 13,6 \\
\hline Peru & 0,747 & $82^{\circ}$ & 10,1 \\
\hline Equador & 0,732 & $93^{\circ}$ & 8,4 \\
\hline Cabo Verde & 0,715 & $100^{\circ}$ & 26,2 \\
\hline
\end{tabular}

Fonte: Pnud e Unesco (2000).

Portanto, na perspectiva da construção de um Estado mais democrático e homogêneo em termos de justiça social, desenvolvimento econômico e educacional, questões estruturais têm sido delegadas a segundo plano.

Políticas de inclusão e de investimento específicas para reduzir esses índices de exclusão social, de modo a providenciar progressivamente os recursos necessários para que, localmente, bairros, regiões, Municípios e Estados consigam sair dessa condição são urgentes.

Mais uma vez, de um lado tem-se o Plano Estadual de Educação - Proposta da Sociedade Paulista, em acordo com o Plano Nacional de Educação - Proposta da Sociedade Brasileira, que chama atenção dos cidadãos para a necessidade de transformar a sociedade. Aqui a educação desempenha um importante papel social na formação dos cidadãos, uma vez que, conscientes do seu papel social, possam ter instrumentos para atuar no sentido de diminuir as desigualdades sociais. De outro lado, tem-se a mesma formula montada com uma lógica diferente: a da educação como serviço prestado pelo Estado, que pode ser financiada por quem se dispuser a isso, voltada para a capacitação e hierarquizada para atender às demandas do 
mercado. Assim, o termo educação tem sido utilizado, há muito tempo, como sinônimo de escolarização, guardando ainda estreita relação com o fornecimento de diplomas e certificados.

\begin{abstract}
A educação é aqui entendida como um instrumento de formação ampla, de luta pelos direitos da cidadania e da emancipação social, preparando as pessoas e a sociedade para a responsabilidade de construir, coletivamente, um projeto de inclusão e de qualidade social para o país ${ }^{37}$.
\end{abstract}

A educação, no entanto, como política pública, deve estar associada à idéia de sistema, pois remete ao fato de que existem diferentes fatores que atuam com os mesmos fins e propósitos a serem atingidos, de forma organizada, coordenada e integrada, numa distribuição geográfica definida. Dessa maneira, há a concepção de um Sistema de Educação ${ }^{38}$ como expressão institucional do esforço organizado, autônomo e permanente do Estado e da sociedade, cujo objetivo é construir, de forma articulada, as diferentes instâncias e níveis da administração e as escolas estas, diversas em múltiplos aspectos -, para que sejam unificadas pelos mesmos objetivos e diretrizes de organização e, sobretudo, para que garantam um mesmo padrão de ensino, de boa qualidade ${ }^{39}$.

Pode-se afirmar então, que não havendo um objetivo comum para orientar todas as ações a serem realizadas e sem uma conjugação de esforços, há duplicidade de providências, falta de planejamento articulador, dispersão de recursos, e a idéia de que o sistema se esfacela.

Um sistema de ensino deve ainda dar conta de aperfeiçoar seus professores em serviço, dada a natureza de seu objeto de trabalho, o conhecimento em constante transformação. Isso implica duas dimensões indissociáveis e igualmente importantes: a transmissão de saberes constituídos e a construção de novos

37 Fórum Nacional em Defesa da Escola Pública, Plano Nacional de Educação - Proposta da Sociedade Brasileira, p. 9.

38 A concepção de sistema refere-se à multiplicidade de conhecimentos articulados segundo uma idéia de totalidade [...] este (sistema) nasce só por conexão e ordenação segundo um comum princípio ordenador, por meio do qual se atribui a cada parte no todo, seu lugar e função impermutáveis. Walter BRUGGER, Dicionário de Filosofia, p. 382.

39 Cf. Fórum Nacional em Defesa da Escola Pública, Plano Nacional de Educação - Proposta da Sociedade Brasileira, pp. 22-23. 
conhecimentos. Na Lei de Diretrizes e Bases da Educação Nacional, esta obrigação está disposta da seguinte maneira em seu artigo 67:

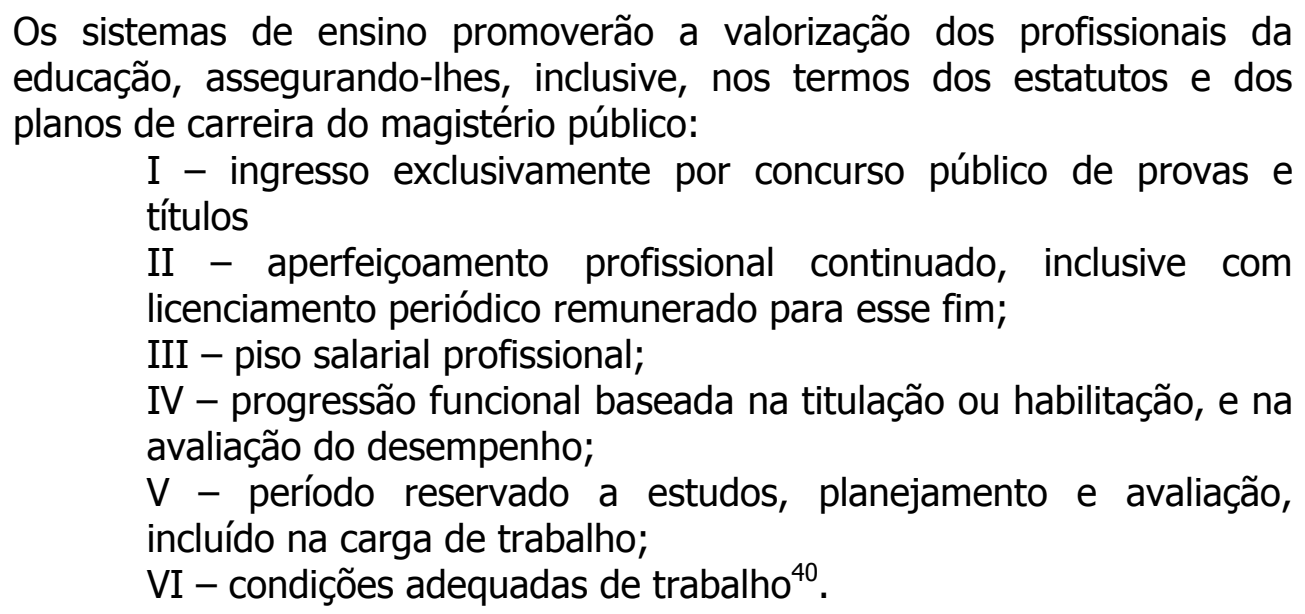

A consecução dos projetos político-pedagógicos das escolas públicas e o fortalecimento dos sistemas educacionais em qualquer nível dependem, em grande parte, desta valorização dos profissionais disposta em lei, quer pela formação continuada em si, quer pelo fortalecimento das relações entre os diferentes níveis e modalidades e seus participantes. É nesse momento que aumenta a possibilidade de objetivar o processo de gestão democrática, com o acesso de todos ao conhecimento socialmente acumulado e sua revisão constante.

Como já mencionado, a ampliação do direito à educação de populações historicamente excluídas da escola remete a discussões que ganharam força desde a década de 1970, no bojo do debate sobre a democratização do ensino. As pressões da população tornaram-se cada vez mais intensas, por haver um pensamento disseminado que aliava a educação à possibilidade de ascensão social.

Retomando, pode-se dizer que a Constituição Federal de 1988 marcou a intenção de construir uma sociedade livre, justa e igualitária, capaz de erradicar o quadro de pobreza e marginalidade, reduzir as desigualdades sociais e regionais e, ao mesmo tempo, superar todos os tipos de preconceitos - origem, raça, sexo, cor, idade e outras formas de discriminação.

40 Lei 9.394/96, Lei de Diretrizes e Bases da Educação Nacional (LDB). 
A realidade social, no entanto, continua apresentando dados não condizentes com a proposição constitucional, principalmente no âmbito educacional. É discurso corrente que a construção da cidadania, entendida como resultado de históricas lutas desenvolvidas pelos diferentes grupos sociais, seja estratégica na formação de novos sujeitos sociais e possibilite a reversão dessa situação. A promoção de valores como respeito à diversidade cultural, racial e étnica, ao meio ambiente, à orientação sexual, aos direitos humanos e à tolerância não pode ser implementada apenas como mero conteúdo, mas incorporada como prática no cotidiano escolar.

Se assim não for, corre-se o risco de, a exemplo do que acontece com relação ao comprometimento da sociedade para com a criança e o adolescente, terse uma das legislações mais avançadas e, de outro lado, ostentar elevadíssimos índices anti-sociais.

Neste exemplo, a concretização dos direitos humanos detalhados a partir do Estatuto da Criança e do Adolescente (Lei Federal n. 8.069/1990, ECA), que ensejou a implementação de diversas instâncias como Conselhos Municipais, Estaduais e Nacional dos Direitos da Criança e do Adolescente, Conselhos Tutelares, Fóruns de Direitos da Criança e do Adolescente, demanda um comprometimento de todos - da família, da comunidade e do Estado.

A criação de leis como essa, no final da década de 1980 e início dos anos de 1990, reflete, de certo modo, uma preocupação dos legisladores em criar leis que dêem conta, ainda que de forma utópica, dos anseios da maioria da sociedade, bem como das discussões travadas no âmbito internacional. A Declaração Mundial de Educação para Todos, realizada em março de 1990 em Jomtien (Tailândia), ratificou, de maneira detalhada, o ideário proposto quarenta anos antes pela Declaração Universal dos Direitos Humanos ${ }^{41}$. Citada como documento-base na construção do Plano Nacional de Educação (Lei 10.172/01), estabelece como princípio básico que

41 A Declaração Universal dos Direitos Humanos foi fruto de dois anos de trabalho e teve sua promulgação aos 10 de dezembro de 1948. Numa época em que a ONU contava com 58 países membros, 48 votaram a favor, oito abstiveram-se e houve duas ausências. É importante destacar que este documento refletiu as preocupações presentes tanto na "Declaração dos Direitos do Homem e do Cidadão" (documento oriundo da Revolução Francesa de 1789), como na "Constituição Americana" de 1791. 
"toda a pessoa tem direito à educação". Assim, sua importância como documento consensuado por 150 países fica demonstrada quando seu conteúdo desponta como imprescindível nas discussões tanto do governo nacional como da sociedade civil organizada, pois estabelece metas como a erradicação do analfabetismo e a universalização da educação básica.

O artigo $1^{0}$ da Declaração Mundial de Educação para Todos discute a educação como estratégia para satisfazer as necessidades básicas de aprendizagem, para que toda pessoa possa desenvolver suas potencialidades, saber como obter informação e conhecimentos, e assumir atitudes e valores em favor do bem comum. Pontua a educação como processo que não está restrito à escola, embora essa tenha um papel fundamental na disseminação e construção de conhecimento, e deva, portanto, empenhar-se nessa tarefa.

A universalização do acesso a uma educação de igual qualidade para todos influenciou o Plano Nacional de Educação - Proposta da Sociedade Brasileira. Seus relatores buscaram no conceito de padrão unitário de qualidade, argumentado por Saviani, a seguinte articulação:

Um sistema não é unidade na identidade, uma unidade monolítica indiferenciada, mas unidade na diversidade, um todo que articula a uma diversidade de elementos que, ao se integrarem ao todo, nem por isto perdem sua própria identidade ${ }^{42}$.

O plano nacional define educação de qualidade como aquela que é acessível e inclusiva, ou seja, que abre oportunidades para grupos historicamente excluídos e promove as reformas educacionais necessárias para que as escolas possam propiciar um ambiente adequado à aprendizagem no sentido de fortalecer as alianças e de enfatizar que nenhuma aprendizagem se dá no isolamento ${ }^{43}$.

Como requisitos, o plano nacional aponta tanto a criação de um contexto político que estabeleça uma aliança entre as instâncias do poder público e da

42 Fórum Nacional em Defesa da Escola Pública, Plano Nacional de Educação - Proposta da Sociedade Brasileira, Caderno do 40 Coned, p. 30.

43 Cf. Declaração Mundial de Educação para Todos, artigo $6^{\circ}$. 
comunidade, quanto a mobilização de recursos financeiros e humanos para que esta tarefa possa ser cumprida.

Assim, nos documentos nacionais, sejam os legais ou os oficiais, as duas premissas deveriam também aparecer atreladas, isto é, a carta de intenções e a forma de financiamento para que ela efetivamente transforme-se em ação, ou seja, para que não se torne um discurso vazio.

De qualquer forma, na medida em que essa declaração coloca como prioridade $o$ atendimento de todos pelos projetos de educação nacionais, acaba por desencadear movimentos intensos por parte daqueles que foram historicamente excluídos da educação, como, por exemplo, os deficientes. O "todos", desta feita, passa a ser alargado e as propostas passam a ter que, cada vez mais, dar conta das especificidades.

Nessa conjuntura, é redigida a Declaração de Salamanca, documento assinado por representantes de 88 governos e 25 organizações internacionais reunidos em assembléia durante a Conferência Mundial de Educação Especial, entre 7 e 10 de junho de 1994. Nela, o direito de todas as pessoas à educação é afirmado, conforme a Declaração Universal de Direitos Humanos, de 1948. Ela renova o empenho da comunidade mundial, na Conferência Mundial sobre Educação para Todos, de 1990, de garantir esse direito a todos, independentemente de suas diferenças. Além disso, afirma que a diferença é própria da humanidade e que esta, portanto, não pode ser fator de discriminação. Nesse sentido coloca entre os pontos que foram proclamados que "aqueles com necessidades educacionais especiais devem ter acesso à escola regular, que deve acomodá-los dentro de uma pedagogia centrada na criança e ser capaz de satisfazer tais necessidades ${ }^{\prime \prime 4}$.

Esse documento indica que os governos locais devem estabelecer como maior prioridade, tanto política como financeira, o aprimoramento dos sistemas de ensino para se tornarem aptos a incluírem todas as crianças. Essa é a referência mais concreta da mudança de paradigma da integração para a inclusão, pois propõe uma mudança social para que seja possível lidar com toda a diversidade humana, e

44 Declaração de Salamanca - de princípios, política e prática para as necessidades educativas especiais, texto no site www.cedipod.org.br/salamanc.htm. 
não uma adaptação do indivíduo ao padrão considerado de normalidade. Por esse motivo, a Declaração de Salamanca pode ser considerada um divisor de águas como perspectiva de acesso à educação elaborada para um grupo que, historicamente, tem sido excluído, pois caminha no sentido oposto ao da classificação e patologização do indivíduo, privilegiando uma leitura da deficiência como diferença, e dessa como inerente à condição humana. Ela não se propõe, entretanto, a ser um receituário de ações que, quando aplicadas "corretamente", tendem a dar "bons" resultados. Dessa forma, se diferencia como concepção das leis nacionais, as quais influenciou. No corpo do texto fica claro que a pretensão é de, ao contrário, indicar em linhas gerais quais políticas públicas devem ser implementadas nessa direção, ou seja, para dar conta da educação de todos.

Escolas regulares que possuam tal orientação inclusiva constituem meios mais eficazes de combater atitudes discriminatórias criando-se comunidades acolhedoras, construindo uma sociedade inclusiva e alcançando educação para todos; além disso, tais escolas provêem uma educação efetiva à maioria das crianças e aprimoram a eficiência e, em última instância, o custo da eficácia de todo o sistema educacional ${ }^{45}$.

A Declaração indica ainda que todas estas mudanças devem ser postuladas em forma de lei ou de política, como no caso brasileiro, e, finalmente, recomenda que a educação especial seja parte integrante de todos os sistemas educacionais.

Mais uma vez fica óbvia a intenção do governo brasileiro em adotar as propostas da Declaração em seu conjunto de leis para a educação, e de como este documento também contempla as preocupações da sociedade civil organizada. Cabe ressaltar, entretanto, que, em ambos os planos, a nomenclatura integração/inclusão é usada de forma indiscriminada e substitutiva em alguns casos. Porém, no PNE/MEC não há avanço significativo em relação à Constituição de 1988, anterior à Declaração de Salamanca, a qual postula em seu artigo 208, inciso III, que "o direito de as pessoas com necessidades educacionais especiais receberem educação preferencialmente na rede regular de ensino". O termo preferencialmente abre uma

45 Idem, www.cedipod.org.br/salamanc.htm. 
"brecha legal" para que, novamente, se instaure um movimento de avaliação e posterior classificação que designe se há ou não a possibilidade de determinada criança ou adolescente freqüentar uma escola regular, além de denotar um certo sentido de reversibilidade na leitura da lei. Pode-se observar ainda que há uma adesão ao termo "necessidades educacionais especiais", postulado na Declaração de Salamanca, o que marca uma noção de mudança na perspectiva do atendimento educacional dessas pessoas. Como afirma Beisegel, no entanto,

mudança é um termo muito genérico que pode significar melhora ou piora [...] da qualidade da mudança que podemos afirmar se houve desenvolvimento ou não. Este se manifesta sempre que há modificações para a realização de algo e que tal realização se dê de maneira irreversível $^{46}$.

Nesse sentido, não se trata de afirmar uma mudança efetiva no entendimento quanto à possibilidade de acesso dessas pessoas à rede regular de ensino, mas fica assinalada a intenção da construção de um processo de uma educação inclusiva.

Os sistemas de ensino devem constituir e fazer funcionar um setor responsável pela educação especial, dotado de recursos humanos, materiais e financeiros que viabilizem e dêem sustentação ao processo de construção da educação inclusiva ${ }^{47}$.

O PNE - Proposta da Sociedade Brasileira, por sua vez, avança um pouco mais na questão, mesmo utilizando a terminologia de forma difusa. Apropria-se mais firmemente dos princípios postulados pela Declaração de Salamanca. No diagnóstico que trata da educação nacional, enuncia a seguinte proposição no que se refere à educação especial:

A educação especial, sempre tratada como apêndice da educação regular, com caráter assistencialista, discriminatório e, portanto, excludente,

46 Celso de Rui BEISIEGEL, op. cit., p. 27.

47 Resolução CNE/CEB n. 2/01, institui as diretrizes nacionais para educação especial na educação básica. 
continua com tal conotação na nova $\operatorname{LDB}^{48}$. Não fica explícito se o Estado assumirá a educação especial em todos os níveis e modalidades de ensino [...] constata-se que, a depender do poder público, não há políticas para mudanças significativas ao atendimento às pessoas com necessidades educativas especiais, seja quanto ao acesso, seja quanto à qualidade desse atendimento. Se paralelamente ao avanço da concepção inclusiva de educação especial, não corresponderem ações concretas de financiamento que garantam essa política, a segregação e a não integração do indivíduo com necessidades educativas especiais poderá ser reforçada ${ }^{49}$.

Há aí, notadamente, uma preocupação para que não haja apenas aquisição de um discurso mais avançado sem que isto corresponda à efetivação de medidas práticas para garantir "um contexto de mudança sistêmica" que vai sendo delineado na medida em que continua descrevendo sua proposta política.

\begin{abstract}
A política inclusiva proposta neste PNE não consiste apenas na permanência física dos portadores de necessidades educacionais especiais junto aos demais alunos. Representa sim, a ousadia de rever concepções e paradigmas nos quais o importante é desenvolver o potencial destas pessoas, respeitando suas diferenças e atendendo suas necessidades [...] a educação especial é concebida com os mesmos objetivos da educação geral e fica incluída em todos os níveis e modalidades de ensino da educação regular. Esta política inclusiva e integradora exige intensificação, quantitativa e qualitativa, na formação de recursos humanos e garantia de recursos financeiros e serviços públicos especializados para assegurar 0 desenvolvimento dos alunos ${ }^{51}$.
\end{abstract}

Pode-se notar uma proximidade de princípios aos propostos na Declaração de Salamanca:

48 A Lei de Diretrizes e Bases da Educação Nacional - LDB 9.394/96 é posterior à Declaração de Salamanca (1994).

49 Fórum Nacional em Defesa da Escola Pública, Plano Nacional de Educação - Proposta da Sociedade Brasileira, p. 13.

50 Declaração de Salamanca - de princípios, política e prática para as necessidades educativas especiais. Salamanca - Item 3 (que faz referência às demandas aos governos).

51 Fórum Nacional em Defesa da Escola Pública, Plano Nacional de Educação - Proposta da Sociedade Brasileira, p. 13. 
O princípio que orienta esta Estrutura ${ }^{52}$ é o de que escolas deveriam acomodar todas as crianças independentemente de suas condições físicas, intelectuais, emocionais, lingüísticas ou outras. Aquelas deveriam incluir crianças deficientes e superdotadas, crianças de rua e que trabalham, crianças de origem remota e população nômade, crianças pertencentes a minorias lingüísticas, étnicas ou culturais, e crianças de outros grupos desvantajados ou marginalizados. Tais condições geram uma variedade de diferentes desafios aos sistemas escolares. No contexto desta estrutura, 0 termo "necessidades educacionais especiais" refere-se a todas aquelas crianças ou jovens cujas necessidades educacionais especiais se originam em função de deficiências ou dificuldades de aprendizagem. Muitas crianças experimentam dificuldades de aprendizagem e, portanto, possuem necessidades educacionais especiais em algum ponto durante sua escolarização. Escolas devem buscar formas de educar estas crianças bemsucedidamente, incluindo aquelas que possuam desvantagens severas. Existe um consenso emergente de que crianças ou jovens com necessidades educacionais especiais devam ser incluídas em arranjos educacionais feitos para a maioria das crianças. Isto levou ao conceito de escola inclusiva. [...] O mérito de tais escolas não resida somente no fato de que elas sejam capazes de prover uma educação de alta qualidade a todas as crianças: o estabelecimento de tais escolas é um passo crucial no sentido de modificar atitudes discriminatórias, de criar comunidades acolhedoras e de desenvolver uma sociedade inclusiva ${ }^{53}$.

Em diversos pontos, a Declaração de Salamanca atualiza a discussão não apenas sobre a educação de crianças deficientes. Postula, de alguma forma, o rompimento entre a educação comum e a especial, e avança defendendo o acesso e a permanência de todos na escola, que deve primar pela busca da qualidade, ou seja, uma concepção integrada de políticas sociais em que a qualidade da educação só pode ser entendida como parte da mesma. O desafio passa a ser formar critérios flexíveis que possam ser utilizados tanto na avaliação externa como na interna, com metas a serem atingidas processualmente. A qualidade educacional é, portanto, um conceito socialmente construído, pois se baseia em direitos, necessidades e demandas. Parte do possível para o utópico e se dá por meio de negociações políticas que ocorrem em diversas instâncias, mas que têm sua concretização

520 arrazoado produzido em Salamanca é dividido em duas partes: a Declaração propriamente dita e o documento intitulado "Estrutura de Ação em Educação Especial". O trecho é o item 3 da introdução deste segundo momento.

53 Declaração de Salamanca - de princípios, política e prática para as necessidades educativas especiais, www.cedipod.org.br/salamanc.htm. 
cotidiana no interior de cada unidade escolar. Pensa-se globalmente (conceito universal), mas age-se localmente (a partir do que já existe).

Outro ponto importante que consta do texto extraído do documento em questão refere-se ao conceito propriamente dito de necessidades educacionais especiais e de sua possível transitoriedade. Ou seja, uma deficiência definida sob os parâmetros anteriores pode ou não ser uma necessidade educacional especial, e vice-versa. Um exemplo para tal afirmação é o caso de alguém que, por ser míope, não consegue se alfabetizar caso não use óculos durante as aulas. À medida que sua miopia é corrigida pelo uso do objeto apropriado, a dificuldade é vencida. O caso contrário pode ser ilustrado pelo ingresso de um cadeirante na escola. Não há, a não ser por uma incapacidade física do equipamento escolar, necessidade educacional especial alguma, embora, notadamente, este quadro seja definido como deficiência física.

O atendimento à diversidade da clientela escolar como parâmetro de avaliação da qualidade social da educação enfatizando o direito à escolarização das populações, historicamente excluídas deste processo, é tido como indisponível ${ }^{54}$, o que aponta para uma mudança de perspectiva social.

A título de atualização, após a Declaração de Salamanca aqui analisada, o Brasil ainda foi signatário de várias outras declarações internacionais que tinham como intuito atualizar a agenda internacional dos países para viabilizar uma educação para todos. Os encontros mais relevantes cujos documentos podem ser encontrados no endereço eletrônico da Unesco ${ }^{55}$ foram: Nova Delhi, 1993, Dakar, 2000 e Cochabamba, 2001.

Todos esses documentos confirmaram compromisso com as metas da Conferência Mundial sobre Educação para Todos, realizada em 1990, no sentido de atender às necessidades básicas de aprendizagem de todos por meio da universalização da educação básica e da ampliação das oportunidades de

54 Cf. Oscar José PLÁCIDO E SILVA, Vocabulário Jurídico, 1967, p. 458. Essa designação refere-se a uma qualidade atribuída a um direito, neste caso, à educação, que não possibilita sua transferência ou disposição, não pode ser vendida nem alheada sob qualquer pretexto. "É atributivo da condição das coisas que se acham sob imposição de indisponibilidade". Alguns juristas chamam-no de direito-dever. 55 Unesco - United Nations Educational, Scientific and Cultural Organization. www.unesco.org.br. 
aprendizagem para crianças, jovens e adultos, na perspectiva da educação para todos.

\begin{abstract}
A educação enquanto um direito humano fundamental é a chave para um desenvolvimento sustentável, assim como para assegurar a paz e a estabilidade dentro e entre países e, portanto, um meio indispensável para alcançar a participação efetiva nas sociedades e economias do século XXI. Não se pode mais postergar esforços para atingir as metas de Educação para Todos. As necessidades básicas da aprendizagem podem e devem ser alcançadas com urgência ${ }^{56}$.
\end{abstract}

Em Dakar foi firmado um compromisso coletivo para a ação - Marco de Ação de Dakar, impondo aos governos a obrigação de assegurar que os objetivos e as metas de educação para todos fossem alcançados e mantidos. Nesse documento, há uma fomentação para parcerias internas e externas para atingir de forma mais eficaz o objetivo de "uma educação que se destina a captar os talentos e potencial de cada pessoa e desenvolver a personalidade dos educandos para que possam melhorar suas vidas e transformar suas sociedades ${ }^{\prime \prime 57}$.

Em Cochabamba, os Ministros da Educação da América Latina e do Caribe, reunidos a pedido da Unesco na VII Sessão do Comitê Intergovernamental Regional do Projeto Principal para Educação (Promedlac VII), reconheceram que a execução do projeto de educação para todos no curso das duas últimas décadas representou um esforço importante por parte dos países para tornar a educação uma prioridade nas agendas de desenvolvimento e, mais uma vez, reafirmaram os objetivos principais: a escolarização fundamental para todos, a alfabetização de jovens e adultos, a melhoria da qualidade e a eficiência da educação.

Em ambos os encontros, Dakar e Cochabamba, foram realizadas análises de conjuntura com relação à educação. A avaliação de 2000 demonstra que mais de 113 milhões de crianças continuam sem acesso ao ensino primário, que 880 milhões de adultos são analfabetos e que a qualidade da aprendizagem e da aquisição de valores e habilidades humanas estão longe das aspirações sociais. Aponta ainda que

56 Declaração de Dakar, Marco de Ação de Dakar, www.unesco.org.br.

57 Idem, ibidem. 
"sem um progresso acelerado na direção de uma educação para todos, as metas nacionais e internacionais acordadas para a redução da pobreza não serão alcançadas e serão ampliadas as desigualdades entre nações e dentro das sociedades ${ }^{\prime \prime 58}$.

Em 2001, as análises, levando em conta dados da América Latina e do Caribe, assinalaram que existem ainda cerca de quarenta milhões de analfabetos com mais de quinze anos, representando mais de $11 \%$ da população total da região. Com relação aos outros objetivos, o quadro não é melhor. Além de não se ter garantida a educação fundamental para todos, pois algumas crianças não são matriculadas e persistem taxas significativas de repetência e evasão, apontam que são necessários maiores esforços para proporcionar serviços educacionais de melhor qualidade, dadas as sérias diferenças que persistem entre os países e dentro deles.

Nesse sentido, pode-se inferir que há algo que se sobrepõe aos esforços para melhorar a educação no mundo. Pode-se aceitar, no entanto, que os acordos foram estabelecidos no nível do discurso e que pouco foi feito de efetivo para que a situação da educação mundial fosse alterada significativamente. De qualquer forma, todos os encontros estabelecem que é obrigação dos governos nacionais efetivarem políticas que atendam às demandas educacionais locais com vistas ao projeto mundial de Educação para Todos.

Dessa forma, é possível afirmar que os documentos internacionais influenciaram sobremaneira a legislação brasileira. De fato, pelo menos no âmbito legal, as diretrizes internacionais estão contempladas, ainda que alinhavando um discurso genérico que aponta, ao mesmo tempo, para duas direções, não necessariamente antagônicas. Essas encontraram ressonância, pois vêm sendo construídas ao longo da história do movimento educacional brasileiro. Atualmente, ainda temos como discurso corrente que educação é entendida como essencial e estratégica para o desenvolvimento, na medida em que o domínio do conhecimento cria condições para a participação consciente nos processos de decisão coletiva, para a contribuição no sistema produtivo e para o gozo da riqueza socialmente gerada

58 Declaração de Dakar, Marco de Ação de Dakar, www.unesco.org.br. 
aliado à necessidade da construção de um projeto de nação que tenha como eixos a ordem democrática, a garantia dos direitos da cidadania e a eqüidade social, com vistas à sua conversão em um país produtivo e competitivo no contexto mundial.

Temos, então, duas direções. Quando fala em democracia, cidadania e eqüidade social, por certo tenta apropriar-se de um discurso que parece questionar a ordem vigente, o que permite a interpretação de que se quer mudá-la. Ao preocupar-se com a conversão do país em "produtivo e competitivo no contexto mundial", a tônica passa a ser a idéia de privilegiar um modelo mercadológico.

A análise de textos legais ou oficiais, pelo fato de que esses se constituem num conjunto de regras pretensamente gerais, é condição para entender seu significado e suas possibilidades de implementação. Em sociedades democráticas, pressupõe-se que haja um esforço coletivo para que tais textos sejam representativos das opções do conjunto da sociedade e que sejam um consenso possível, retrato de determinada época. 0 fato de que, efetivamente, tenha ocorrido uma disputa no sentido de elaborar um plano nacional de educação, documento que vinha sendo apontado como essencial desde o início do século passado para que a educação fosse considerada prioritária a despeito do governo que estivesse à frente do país, é sem dúvida uma mostra de que há possibilidade de intervenção.

Ainda que estejamos numa sociedade classista, como afirma Freire ${ }^{59}$, em que prevalece a pedagogia do dominante ou do opressor, dado que as relações são governadas/guiadas pelos interesses de grupos (classes e/ou nações dominantes) e as instituições parecem sempre tender a privilegiar os interesses dos que detêm a hegemonia, marcas dos outros grupos foram deixadas. Ou seja, mesmo que prevaleçam nos textos legais e oficiais os discursos dos setores dominantes, de alguma forma eles tiveram de contemplar os anseios de outros setores da sociedade, mesmo que não com a pujança esperada.

Assim, tanto os textos legais do Brasil e do Estado de São Paulo, como os textos produzidos pelo Fórum Nacional em Defesa da Escola Pública e alguns acordos internacionais dos quais o Brasil é signatário, como a Declaração de Educação

59 Cf. Paulo FREIRE, Pedagogia do Oprimido, 2002, pp. 29-56. 
Mundial para Todos, a Declaração de Salamanca, a Declaração de Nova Delhi, o Marco de Ação de Dakar e a Declaração de Cochabamba, têm, em suas definições do objeto educacional, termos recorrentes como democratização do ensino (acesso e permanência) e qualidade educacional numa perspectiva de uma educação inclusiva ou de inclusão educacional e social de todos.

Essa tentativa de aproximação dos dois vocabulários pode ser entendida como a utilização de conceitos programáticos ${ }^{60}$ como se fossem conceitos descritivos ${ }^{61}$, para dar uma falsa noção de consenso retórico que, na prática, apresentam-se das mais diversas formas, ao que Minto chamou de discursos pasteurizados ${ }^{62}$.

Esse mesmo movimento, porém, abre "brechas" que possibilitam a atuação de toda a sociedade e de cada um. Se o que parece estar em jogo é a construção de um país que seja competitivo segundo uma perspectiva globalizada, a conseqüente busca por qualidade e competitividade depende, entre outras coisas, da adoção de inovações tecnológicas educacionais e da capacitação da mão-de-obra.

Assim, tendo como utopia entendida - no sentido freireano, ou seja, como antecipações criadoras - a conquista da educação de qualidade para todos, o mérito maior estaria exatamente na ação transformadora e não apenas no discurso propriamente dito, que, sem a primeira, torna-se vazio, mera declaração de intenções.

A preocupação em verificar a legislação educacional, nucleada nos planos de educação, entendidos como definidores de uma política educacional apontada para este início de século, permite contemplar a formação de cidadãos, não apenas no sentido de as pessoas terem os direitos básicos garantidos no "contrato social" (que as leis representam ou deveriam representar), mas, sobretudo, no da possibilidade

60 Conceitos que acrescentam ao uso prévio novos usos, fundados em razões morais e repercussões práticas.

61 Conceitos de uso prévio ou firmado, cuja definição pressupõe uma delimitação.

62 Cf. César Augusto MINTO, Legislação educacional e cidadania virtual, anos 90, 1996, pp. 144-152. Os discursos pasteurizados são - deliberadamente ou não - ambíguos e/ou omissos, permitindo várias interpretações. Em geral, diluem polarizações, mas representam, nas leis, o resultado historicamente possível; por isso, nem sempre são socialmente nocivos, sendo "convenientes" à maioria. Volto a tratar deste assunto um pouco mais adiante. O termo pasteurização é usado com a conotação de fruto de embates entre discursos antagônicos, podendo sugerir imagens negativas. 
de lutarem para fazer valer tais direitos. Estas podem exercer maior ou menor pressão sobre as autoridades constituídas, executando atividades que podem ou não aumentar a probabilidade de forjar para a cidadania e, portanto, redimensionar o cenário educacional brasileiro.

Reconhecer o quão nefasto é o sistema educacional atual, que não inclui a todos, e denunciá-lo, é apenas parte da tarefa. Não assumir uma posição fatalista frente à realidade histórica que se impõe e vivenciar uma prática educativa que estimule o papel de sujeito do conhecimento podem possibilitar ações coletivas que superem a dicotomia entre pensadores e executores, assim como o fortalecimento de relações baseadas na ética humana ${ }^{63}$.

63 Cf. Paulo FREIRE, Pedagogia da Indignação: cartas pedagógicas e outros escritos, 2000, pp. 117134. 


\section{As Diretrizes Educacionais do MunicíPio de SÃo PAUlo}

A universalização do acesso a uma educação de igual qualidade para todos tem fomentado, desde o final da década de 1980, ações sistemáticas, ou seja, uma articulação de operações na promoção das reformas educacionais necessárias para atingir esse objetivo. Um contexto político que estabeleça uma aliança entre as diversas instâncias do poder público e a comunidade, bem como a mobilização de recursos financeiros e humanos são imprescindíveis para que essa tarefa possa ser levada a cabo.

A questão da qualidade na educação, por sua vez, está cotidianamente sendo revista. Nesse sentido, encontra-se diretamente associada a cada período histórico. Pode-se assinalar que a melhoria da qualidade educacional, em certo momento, tinha como significado principal a expansão da rede física com vistas à universalização do ensino fundamental. 0 empenho em se estabelecerem metas objetivando a permanência na escola foi apontado como fator de indicação de qualidade educacional na proporção em que eram necessárias medidas complementares para garantir as possibilidades educacionais de parcelas da população que saíam da escola sem completar a educação básica, mediante os índices alarmantes de fracasso escolar. Não apenas ter acesso, tampouco somente permanecer, mas buscar conhecimento, postulado como bem social que deve estar acessível a todos em sua forma plena no diálogo diário da escola, pode ser considerada uma visão atualizada do que se entende como uma educação com qualidade.

A perspectiva histórica traçada anteriormente, nos níveis nacional e estadual, e em termos de documentos legais e oficiais, bem como seu aporte internacional, permitiram o delineamento do quadro da educação brasileira. Cabe, então, nesse momento, verificar como esse aparato tem sua correspondência no âmbito municipal. Essa análise é importante pois a escola em que foi desenvolvida a pesquisa está sob a responsabilidade da prefeitura de São Paulo. Assim, uma breve leitura comparativa entre um dos documentos legais mais importantes para a 
federação, a Constituição da República Federativa do Brasil (1988), e seu correspondente no Município, a Lei Orgânica do Município de São Paulo (1990), permite a inferência de algumas dessas conexões.

O artigo $205^{1}$ da Constituição Federal (CF/88) tem nos artigos 200, 203 e 204 da Lei Orgânica do Município de São Paulo (LOM-SP/90) sua referência. $O$ artigo 200 dispõe sobre as bases do sistema municipal de ensino, além da criação do Conselho Municipal de Educação e a elaboração do Plano Municipal de Educação².

A educação ministrada com base nos princípios estabelecidos na
Constituição da República, na Constituição Estadual e nesta Lei Orgânica, e
inspirada nos sentimentos de igualdade, liberdade e solidariedade, será
responsabilidade do Município de São Paulo, que a organizará como
sistema destinado à universalização do ensino fundamental e da educação infantil.

$\S 1^{0}$ - O sistema municipal de ensino abrangerá os níveis fundamental e da educação infantil estabelecendo normas gerais de funcionamento para as escolas públicas municipais e particulares nestes níveis, no âmbito de sua competência.

$\S 2^{\circ}$ - Fica criado o Conselho Municipal de Educação, órgão normativo e deliberativo, com estrutura colegiada, composto por representantes do Poder Público, trabalhadores da educação e da comunidade, segundo lei que definirá igualmente suas atribuições.

$\S 30$ - O Plano Municipal de Educação previsto no art. 241 da Constituição Estadual será elaborado pelo Executivo em conjunto com o Conselho Municipal de Educação, com consultas a: órgãos descentralizados de gestão do sistema municipal de ensino, comunidade educacional, organismos representativos de defesa de direitos de cidadania, em específico, da educação, de educadores e da criança e do adolescente e deverá considerar as necessidades das diferentes regiões do Município.

$\S 40$ - O Plano Municipal de Educação atenderá ao disposto na Lei Federal n. 9.394/96 e será complementado por um programa de educação inclusiva cujo custeio utilizará recursos que excedam ao mínimo estabelecido no artigo 212, § 40, da Constituição Federal.

$\S 50$ - A lei definirá as ações que integrarão o programa de educação inclusiva referido no parágrafo anterior ${ }^{3}$.

1 O Artigo 205 explicita que "a educação, direito de todos e dever do Estado e da família, será promovida e incentivada com a colaboração da sociedade, visando ao pleno desenvolvimento da pessoa, seu preparo para o exercício da cidadania e sua qualificação para o trabalho".

2 Ainda em discussão quando do término deste trabalho.

3 Lei Orgânica do Município de São Paulo de 1990, artigo 200. 
O artigo 203 em seu parágrafo único estabelece os deveres do Município e afirma a cooperação técnica e financeira dos outros entes federados.

\begin{abstract}
É dever do Município garantir:
I - educação igualitária, desenvolvendo o espírito crítico em relação a estereótipos sexuais, raciais e sociais das aulas, cursos, livros didáticos, manuais escolares e literatura;

II - educação infantil para o desenvolvimento integral da criança até seis anos de idade, em seus aspectos físico, psicológico, intelectual e social;

III - ensino fundamental gratuito a partir de 7 (sete) anos de idade, ou para os que a ele não tiveram acesso na idade própria;

IV - educação inclusiva que garanta as pré-condições de aprendizagem e acesso aos serviços educacionais, a reinserção no processo de ensino de crianças e jovens em risco social, o analfabetismo digital, a educação profissionalizante e a provisão de condições para que o processo educativo utilize meios de difusão, educação e comunicação;

$V$ - a matrícula no ensino fundamental, a partir dos 6 (seis) anos de idade, desde que plenamente atendida a demanda a partir de 7 (sete) anos de idade.

Parágrafo único - Para atendimento das metas de ensino fundamental e da educação infantil, o Município diligenciará para que seja estimulada a cooperação técnica e financeira com o Estado e a União, conforme estabelece $o$ art. 30, inciso VI, da Constituição da República ${ }^{4}$.
\end{abstract}

Já seu artigo 204 caracteriza a educação e seus objetivos:

O Município garantirá a educação visando o pleno desenvolvimento da pessoa, preparo para o exercício consciente da cidadania e para o trabalho, sendo-lhe assegurado:

I - igualdade de condições de acesso e permanência;

II - o direito de organização e de representação estudantil no âmbito do Município, a ser definido no Regimento Comum das Escolas 5 .

Esses artigos possibilitam o entendimento do "espírito da lei". A meta da universalização do ensino está privilegiada nos níveis infantil e fundamental, dado que esses são de responsabilidade praticamente exclusiva do Município, na 
perspectiva da igualdade do acesso e da permanência - dois indicadores de qualidade importantes, como já mencionado.

Nessa parte da referida legislação, o que chama atenção é a definição da educação inclusiva como um programa complementar, a ser organizado pelo Município e disposto em lei. Dessa forma, fica definida à parte dos níveis especificados como objetos passíveis de universalização.

Observando ainda a LOM-SP/1990, em seu artigo 203, especificamente o inciso IV, é interessante ressaltar que a terminologia "educação inclusiva" está posta como se fora uma "modalidade", recebendo o mesmo tratamento legal da educação infantil ou fundamental. Essa disposição deixa subentendida a possibilidade de haver, na perspectiva municipal, o estabelecimento de uma diferença entre educação inclusiva e educação para todos. Mais ainda, que há um conjunto de saberes prévios à educação que seriam o objetivo dessa "pseudomodalidade", no sentido, talvez, de preparar o aluno para ter acesso, seja pela primeira vez ou como reinserção.

No artigo 208, que discorre sobre o financiamento, continua sendo tratada de forma isolada, tanto no caput como em seu parágrafo $2^{\circ}$. Assim, tem-se que:

O Município aplicará, anualmente, no mínimo $31 \%$ (trinta e um por cento) da receita resultante de impostos, compreendida a proveniente de transferências, na manutenção e desenvolvimento do ensino fundamental, da educação infantil e inclusiva.

$\S 2^{\circ}$ - A lei definirá as despesas que se caracterizam como de manutenção e desenvolvimento do processo de ensino-aprendizagem, bem como da educação infantil e inclusiva ${ }^{6}$.

Dessa forma, a Lei Orgânica Municipal, no que se refere à definição de verbas públicas para a educação, utiliza novamente a "educação inclusiva" como "pseudomodalidade" que será definida a posteriori por uma lei, a qual não é indicada, também com relação às despesas concernentes para efetivá-la. Assim, embora a LOM-SP tenha contemplado a "educação inclusiva" tanto na "carta de intenções" como na forma de financiamento (duas premissas que deveriam aparecer

6 Idem, artigo 208. 
sempre atreladas), ela está relacionada como se fora uma tarefa à parte do sistema e não avança na especificação sobre a forma como será implementada legalmente.

Essa ressalva com relação à utilização da expressão "educação inclusiva", conceituado de modo difuso e dissociado da forma como vinha sendo apresentado até então nos outros documentos estudados, não invalida o fato de, na Lei Orgânica Municipal, haver uma clara intenção de contemplar as diretrizes nacionais e internacionais no que se refere à universalização das modalidades de ensino infantil e fundamental.

A promulgação da LOM-SP, em 1990, remete a uma análise das diretrizes municipais datadas daquela época, visando a possibilitar o entendimento sobre as questões apontadas até agora no que se refere à educação de qualidade para todos.

Assim, segundo documentos oficiais do Município de São Paulo datados de 1989, a política educacional era implementada no sentido de "construir uma educação popular pública", de modo que ela não fosse "apenas aquela à qual todos têm acesso, mas aquela cuja construção todos podem participar" ${ }^{\prime \prime}$.

O movimento da educação para todos estaria, dessa maneira, contemplado e ampliado para o entendimento de que a gestão democrática de uma escola é fator estruturante para que esta possa dar conta de sua função social: educar o público.

A ação fundamentava-se basicamente em três propostas: a interação com os outros, o estudo da prática do trabalho educacional e o estudo teórico que o fundamenta. Ou seja, o desenvolvimento de projetos escolares vinculava-se à realidade local, num movimento de ação-reflexão-ação descrito por Freire como relação dialógica ${ }^{8}$. A influência dos escritos freireanos pode ser encontrada em todos os documentos analisados, estando contida nas diretrizes apontadas como fundamentais: participação, descentralização e autonomia9 .

7 São Paulo/SP. Secretaria Municipal de Educação. Construindo uma educação popular pública, 1989. 8 Paulo FREIRE, op. cit. , 2002, pp. 77-86. A teoria da ação dialógica desenvolvida por Freire baseiase na colaboração, na união, na organização e na síntese cultural. Na teoria dialógica da ação, os sujeitos se encontram para a pronúncia do mundo e para a sua transformação por intermédio do diálogo, que é sempre comunicação.

9 Cabe lembrar que Paulo Freire ocupou o cargo de Secretário Municipal de Educação (1989-1991) durante o mandato da prefeita Luiza Erundina (1989-1992), sendo substituído por seu Assessor especial e Chefe de Gabinete, Mário Sérgio Cortella. 
A Secretaria Municipal de Educação instituiu, então, os NAEs - Núcleos de Ação Educativa em substituição às DREM - Delegacias Regionais de Educação Municipal, nessa gestão (1989-1992), numa tentativa de alterar a perspectiva da ação supervisora dando a ela um sentido de orientação e não de sanção, como no caso anterior, mas colocando a descentralização e a gestão participativa e autônoma como foco de suas diretrizes.

Sem dúvida, em termos legais, o maior avanço mesmo foi a aprovação da Lei 11.229/92, que dispunha sobre o primeiro Estatuto do Magistério Público do Município de São Paulo ${ }^{10}$. Entre seus princípios norteadores, dispostos no Título I Capítulo I, estão: a gestão democrática, o aprimoramento da qualidade de ensino, a valorização dos profissionais de ensino, e uma escola pública gratuita, de qualidade e laica para todos, que, dessa forma explicitados, contemplam na legislação municipal os parâmetros definidos nacional e internacionalmente. Por se tratar de uma lei bastante completa, cabe, como ilustração, reproduzir o formato e o enunciado de seus títulos e capítulos, para uma idéia global do que era pretendido com a aprovação desse documento:

Título I - Das Disposição Preliminares.

Capítulo I - Princípios Norteadores.

Capítulo II - Campo de Atuação dos Profissionais de Ensino.

Título II - Da Carreira do Magistério.

Capítulo I - Configuração da Carreira.

Capítulo II - Estágio Probatório.

Capítulo III - Acesso.

Capítulo IV - Categorias Profissionais.

Capítulo V - Evolução Funcional.

Título III - Do exercício Dos Cargos do Quadro do Magistério Municipal.

Capítulo I - Composição do Quadro.

Capítulo II - Escolha de Turnos, Classes e/ou Aulas.

Capítulo III - Substituição.

Capítulo IV - Remoção.

Capítulo V - Afastamento.

Título IV - Das Jornadas de Trabalho.

Capítulo I - Modalidades.

Capítulo II - Jornada de Tempo Parcial - JTP.

Capítulo III - Jornada de Tempo Integral - JTI.

Capítulo IV - Regime do Tempo Completo - RTC.

10 Lei 11.229/92 Estatuto do Magistério Público do Município de São Paulo. 


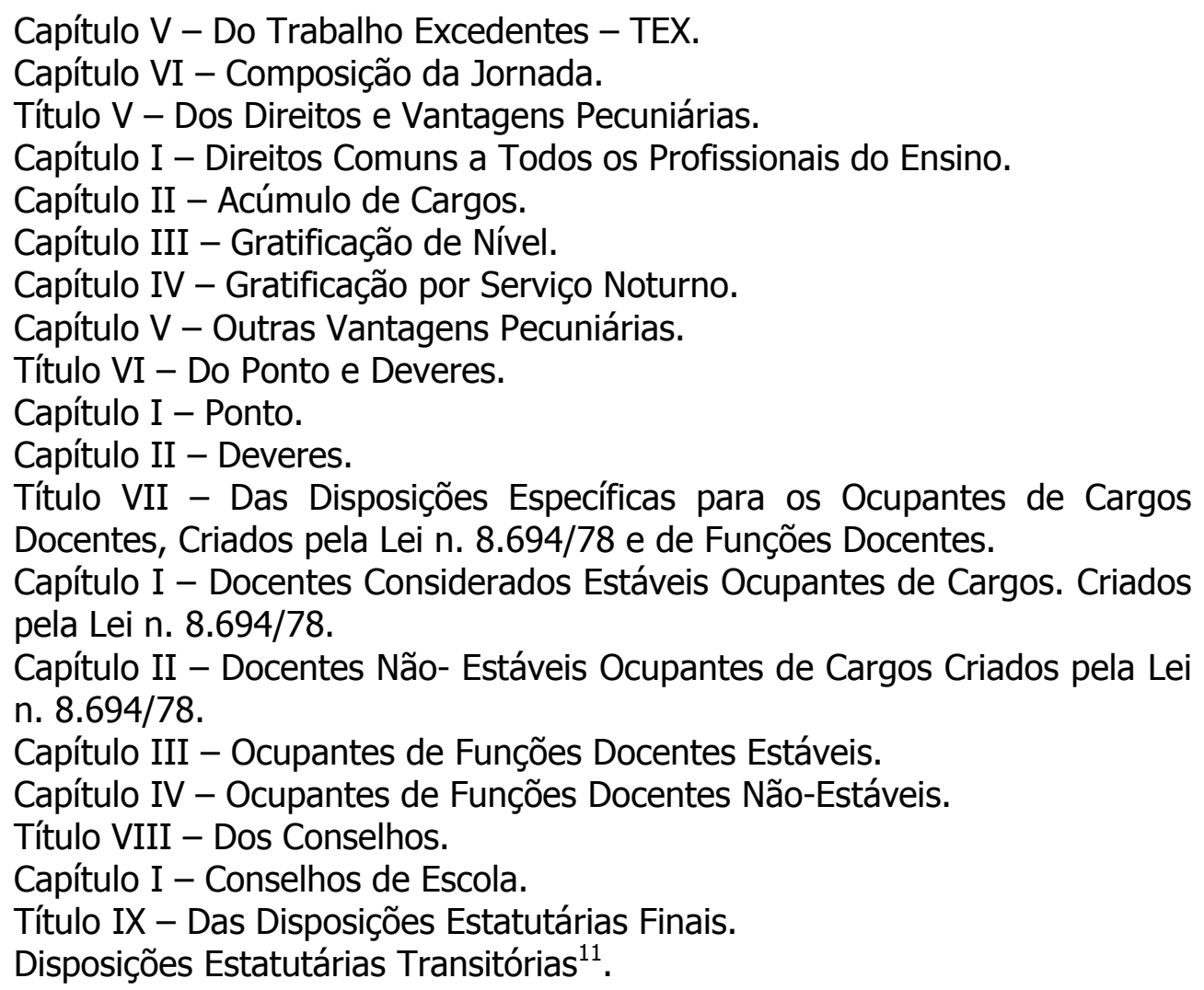

Em linhas gerias, essa lei configura o campo de atuação e a carreira dos profissionais da educação de forma bastante detalhada e dá um passo legal importante, no âmbito municipal, para o entendimento do magistério público municipal como profissão.

Nesse trabalho, o disposto em seu Título IV - Das Jornadas de Trabalho, merece especial destaque, pois viabiliza, em lei, um momento de horário coletivo de trabalho ${ }^{12}$, em que os princípios norteadores postulados ${ }^{13}$ podem ser transformados em ação.

Houve a determinação de dois tipos de jornadas de trabalho:

1. Jornada de Trabalho Parcial - JTP com cem horas de trabalho mensais e até vinte horas de atividade de trabalho coletivo;

\section{Idem}

12 Como a pesquisa ocorreu justamente dentro do horário coletivo de trabalho instituído pela escola, trata-se de importante esclarecimento a indicação de seu respaldo legal.

13 São Paulo/ SP. Secretaria Municipal de Educação, Construindo uma educação popular pública, 1989. 
2. Jornada de Trabalho Integral - JTI que correspondia a 150 horas/mensais, sendo cem em regência de classe e cinqüenta de trabalho coletivo para aprimoramento profissional ( $80 \%$ na escola e $20 \%$ em local de livre escolha).

Nos dois casos, ficou assegurada uma parcela da quantidade total de horas a ser dedicada ao trabalho coletivo, o que demonstra uma preocupação dos gestores municipais em assegurar a participação coletiva na gestão educacional, como aponta o documento Construindo uma Escola Pública Popular.

Em 1993, já na gestão seguinte ${ }^{14}$, foi sancionada a Lei $11.434 / 93^{15}$, criada, segundo relatos da época, para disciplinar as jornadas de trabalho e corrigir o que a gestão municipal chamou de "distorções salariais". Oferecia três jornadas de trabalho, detalhadas nos artigos de 33 a 55 :

1. Jornada Básica - JB - que correspondia a dezoito horas/aula semanais em regência de classe e duas horas/aula em atividades;

2. Jornada Especial Ampliada - JEA - que correspondia a 25 horas/aula semanais em regência de classe e cinco horas/aula em atividades;

3. Jornada Especial Integral - JEI - que correspondia a 25 horas/aula semanais em regência de classe e quinze horas/aula em atividades, sendo onze na escola e quatro em local de livre escolha.

A lei regulava, ainda, o emprego das horas adicionais dos optantes pela JEI. O artigo 41 explicita:

As horas adicionais constituem o tempo remunerado de que dispõe o profissional da educação em Jornada especial Integral, para desenvolver atividades extraclasse, dentre outras:

I - trabalho coletivo da Equipe escolar, inclusive o de formação permanente e reuniões pedagógicas;

II - preparação de aulas, pesquisas e seleção de material pedagógico e correção de avaliações;

14 O prefeito, nesta oportunidade, era Paulo Salim Maluf (1992-1995).

15 A Lei 11.434/93 reenquadra cargos e funções estabelecidos na Lei n. 10.430/88 e na Lei 11.229/92. Na área do ensino municipal, cria novas escalas de padrões de vencimentos e institui planos de carreira. Artigo 10: "Esta lei dispõe sobre a organização dos Quadros dos Profissionais da Educação da Prefeitura do Município de São Paulo". 
III - atividades com a comunidade, e pais de alunos, exceto as de reforço, de recuperação e reposição de aulas;

Parágrafo único: o tempo destinado às Horas-adicionais será cumprido:

a) 11 (onze) horas/aula semanais na própria escola

b) 4 (quatro) horas/aula semanais em local de livre escolha ${ }^{16}$.

Além da JEI, era possível ao professor optante por outra jornada (JEA ou JB) solicitar o ingresso em JEX - Jornada Especial de Hora/Aula Excedente, ou em TEX Jornada Especial de Hora/Trabalho Excedente com expressa autorização da supervisão escolar ${ }^{17}$. No primeiro caso, há a priorização das seguintes atividades: aulas regulares, livres ou em substituição e aulas em reposição ${ }^{18}$. No segundo caso, as atividades devem estar relacionadas com a realização de projetos pedagógicos.

De qualquer forma, pode-se observar um outro entendimento em relação ao anterior, no sentido de flexibilizar o uso das horas coletivas. 0 trabalho coletivo não é priorizado em momento algum nessa nova lei, o que abriu espaço legal para que os optantes utilizassem essas horas remuneradas para trabalhos individuais, descaracterizando a proposta inicial. Há uma transformação das horas coletivas em horas adicionais. As atividades referendadas como parte do desenvolvimento do trabalho coletivo da equipe escolar, como reuniões pedagógicas, preparação de aula, pesquisa, seleção e a correção de material pedagógico, por vezes, podem não caracterizar trabalho coletivo.

Em 1994, o Decreto n. 33.991/94 institui o Regimento Comum das Escolas Municipais mantidas pela Prefeitura Municipal de São Paulo, que atribui a esses estabelecimentos o princípio da gestão coletiva, tendo no "Conselho de Escola a instância de elaboração, deliberação, acompanhamento e avaliação do planejamento e do funcionamento da unidade escolar ${ }^{\prime \prime 19}$. O Conselho de Escola tem várias atribuições, dentre elas, a discussão e a adequação das diretrizes da política educacional para o atendimento das especificidades locais, trabalhando na definição

16 Lei $11.434 / 93$, artigo 41.

17 Voltam as DREM - Delegacias Regionais de Educação Municipal e, com elas, a perspectiva da supervisão volta a ser de fiscalização e sanção.

18 Lei 11.434/93, que reenquadra cargos e funções estabelecidos na Lei $n$. 10.430/88 e na Lei 11.229/92. Artigo 42.

19 Decreto 33.991/94, Regimento comum das escolas municipais. 
de prioridades e metas de ação da escola para cada ano letivo, as quais devem orientar a elaboração do Plano Escolar.

Em $1997^{20}$, a Portaria n. $3 \cdot 826 / 97^{21}$ dá nova dimensão ao PEA, que passa a chamar-se Projeto Especial de Ação. Expressamente subordinado ao Projeto PolíticoPedagógico da escola, caracteriza-se como instrumento voltado à melhoria do processo de ensino-aprendizagem e de natureza pedagógico-institucional. A carga mínima de dedicação é de 44 horas/aula. Podem participar a equipe técnica, na coordenação das atividades, e os optantes por JEI ou JB ou JEA com TEX, que devem ter $85 \%$ de freqüência para receber atestado. O Projeto Especial de Ação passa a ter novas modalidades:

1. Formação e aperfeiçoamento profissional;

2. avaliação diagnóstica;

3. orientação educacional e pré-profissional;

4. ações culturais e artísticas com a comunidade;

5. melhoria da qualidade de vida;

6. formação de cidadania.

Dessa forma, apesar do crescente aumento dos mecanismos de controle no que diz respeito aos horários coletivos e de um alargamento das atribuições da escola (principalmente os pontos quatro, cinco e seis explicitados acima), a análise da legislação municipal deixa claro que há preocupação em planejar levando em consideração as especificidades locais junto com as diretrizes municipais estabelecidas pelas seguidas gestões municipais.

Em termos da escrita legal, os avanços e retrocessos denotam, o que no nível nacional também pode ser observado, uma descontinuidade das políticas educacionais, embora o discurso venha sendo aprimorado para não deixar essas rupturas muito patentes. O discurso aparece cada vez mais aproximado, e o

200 prefeito, nesta época, era Celso Pitta (1997-2000)

21 Esta portaria re-estabelece e redimensiona os Projetos Especiais de Ação, anteriormente nomeados de Projetos Estratégicos de Ação. Estes foram estruturados pela portaria 2.083/93 e, posteriormente, alterados em 1994 e 1996. 
diferencial parece estar na forma de implementar as ações, ora privilegiando o espaço coletivo de discussão ora cerceando-o e tornando-o vazio de sentido.

O horário de trabalho coletivo foi planejado em um mandato municipal cuja diretriz centrava-se na construção da autonomia da escola e dos trabalhadores da educação (1989-1992), e foi organizando-se por vias legais, sem a promoção de diálogo com esses participantes. Assim, constituiu-se um certo tutoramento, que se aproxima de uma heteronomia em relação à construção do conhecimento vinculado ao espaço de trabalho coletivo, que foi se organizando muito mais como um espaço coletivo de trabalho do que um espaço de trabalho coletivo.

O delineamento mais fino da política municipal de cada gestão tem-se alternado significativamente desde 1989. A definição de educação inclusiva, por exemplo, que já aparece na Lei Orgânica do Município de São Paulo (LOA, 1990) começa ganhar mais espaço nos documentos oficiais no ano de 2001, configurandose como uma questão do governo municipal traduzida em proposta de política pública. Sua formulação completa está descrita nos Cadernos EducAção22, cujo primeiro número, lançado no início de 2001, tem como objetivo:

Iniciar o diálogo com a comunidade educativa, educadores, funcionários, pais e alunos da rede municipal [...] que tem como horizonte a construção de uma política educacional em uma escola capaz de promover o desenvolvimento do ser humano em suas inúmeras potencialidades ${ }^{23}$.

Explicita ainda que a articulação de todos os órgãos que compõem o sistema municipal, como as escolas, as $\operatorname{DREM}^{24}$ e os demais órgãos da secretaria é imprescindível para superar dois problemas colocados pelo documento: a fragmentação e a superposição de ações. Aponta o diálogo entre essas instâncias

22 A atual gestão municipal tem como prefeita Marta Suplicy (2001-2004).

23 São Paulo/SP, Secretaria Municipal de Educação, Caderno EducAção, n. 1 , p. 4.

24 DREM - Delegacias Regionais de Educação que foram transformadas em NAE - Núcleos de Ação Educativa (primeiro semestre de 2001) com o propósito, conforme o Caderno EducAção, n. 1, p.7, de inverter a lógica de estruturação do trabalho técnico-administrativo em razão do desenvolvimento das diretrizes educacionais, e não o contrário. 
como fator fundamental para que "a reflexão, o planejamento, o registro e a ação se estabeleçam como procedimentos permanentes e contínuos" ${ }^{\prime 25}$.

A proposta afirma também que a atual gestão alinha-se com uma concepção de educação como direito, em contraposição à visão dessa como mercadoria ou como mera ação compensatória, voltada para minimizar a "exclusão considerada, por muitos inevitável"26, ao adotar a competição como valor medido pelos padrões de qualidade de caráter homogeneizador.

Pode-se observar uma proximidade muito grande entre o que está escrito na Carta de Porto Alegre, detalhada no capítulo anterior, e o que aparece postulado nesse Caderno. Em ambos, há uma preocupação latente em operar uma ligação estrutural entre o social, o econômico e o educacional, para mostrar o quão inviável é pensar num modelo educacional desvinculado das propostas para o País, Estado ou Município, em termos de desenvolvimento econômico e social.

A resignificação da política global de educação para todos no âmbito local, no que diz respeito aos documentos elaborados pelo poder público municipal, está presente no projeto educacional do Município de São Paulo nas três diretrizes estabelecidas por essa gestão: democratização do conhecimento e construção da qualidade social da educação; democratização da gestão e democratização do acesso e permanência.

A primeira é direcionada por uma perspectiva educacional que possibilita que os educandos "experimentem a construção e a transformação do conhecimento como sujeitos de seu processo e de seu tempo histórico tornando-se capazes de compreender o mundo e escolher seu lugar nele ${ }^{\prime \prime 27}$.

A qualidade na educação é conceituada como construção. Destarte, é afirmado que na perspectiva da "ação-reflexão-ação" com o debate permanente a partir de um trabalho coletivo e sistemático é que se terá definida essa noção.

Articular problematização das práticas curriculares, bem como das formas de avaliação, com as reflexões realizadas nos cursos de formação no

25 SÃO PAULO/SP, Secretaria Municipal de Educação, Caderno EducAção, n. 1 , p. 4.

26 Idem, p.5.

27 Idem, ibidem. 
âmbito das reuniões pedagógicas [...] para que o departamento de Orientação Técnica (DOT), as equipes pedagógicas dos futuros NAEs e as escolas possam construir (e não decretar) a qualidade com a qual sonhamos ${ }^{28}$.

Há uma retomada de alguns conceitos explicitados na gestão de 1989-1992, como a ênfase na possibilidade de construção do conhecimento a partir do diálogo e da ação-reflexão-ação. Em termos de gestão, aponta-se a volta da perspectiva da ação supervisora como orientadora. É salientada a necessidade da formação permanente e sistemática ${ }^{29}$ de todos os educadores, estruturada a partir de experiências dos mesmos e das escolas, como forma de proporcionar a reflexão em todos os campos do conhecimento.

A democratização da gestão "contribui para a realização da qualidade social da educação" e "permite que a escola e o conjunto do sistema a ser gerido, no âmbito de competência de cada unidade ou instância, por coletivos representativos, aperfeiçoem as práticas democráticas na cidade ${ }^{\prime \prime 30}$. O respeito nas relações desenvolvidas em todos os níveis, aliado ao conhecimento adquirido no diálogo com a comunidade, funcionaria como qualificador da tomada de decisões e contribuiria para a socialização das informações, possibilitando a participação de um número cada vez maior de pessoas no processo, construção e acompanhamento da política educacional. Para tal, a gestão estabelece como prioridade o aperfeiçoamento do Conselho Municipal de Educação, dos Conselhos de Escola, além da reconstrução dos Creces (Conselhos Regionais dos Conselhos de Escola) e do incentivo à criação dos Grêmios Estudantis ${ }^{31}$.

A diretriz que pontua sobre a democratização do acesso e da permanência, baseada na Constituição Federal e na Lei de Diretrizes e Bases da Educação Nacional (Lei 9394/96) toma como competência municipal:

- manter universalizado o ensino fundamental em discussão com o Estado;

- ampliar progressivamente o atendimento da educação infantil;

28 Idem, p. 7.

29 Cf. Idem, ibidem.

30 Cf. Idem, p. 8.

$31 \mathrm{Cf}$ Idem, ibidem. 
- ampliar o atendimento de jovens e adultos através da suplência redimensionamento do Movimento de Alfabetização de Jovens e Adultos (Mova) em articulação com a formação profissional e, também, em negociação com o governo do Estado;

- criar as condições materiais e pedagógicas para o atendimento aos portadores de necessidades especiais, propiciando que se faça a discussão sobre os modos de inclusão ${ }^{32}$.

No período de 2001-2003 foram lançados ainda mais três números dessa publicação. Ao longo desse tempo, os conceitos veiculados no primeiro número, que tinha justamente a preocupação de delinear os pressupostos da Secretaria Municipal de Educação, foram revistos.

O segundo Caderno EducAção, para além de conceituar perspectivas, parte para uma ação mais diretiva e, no sentido de "estimular" novas formas de organicidade para uma eficácia maior, explicita as definições e atribuições de tarefas. Define a Secretaria Municipal de Educação como órgão central responsável por garantir uma política educacional coesa e articuladora. As escolas, com o compromisso de desenvolver uma educação de qualidade social para todos,

vivenciam as finalidades últimas da educação: criar ambientes de aprendizagem, abrir espaços de participação nos conhecimentos, viabilizar a pesquisa em ação para professores e alunos, divulgar trabalhos culturais que desenvolvam nos alunos e na comunidade escolar o pleno sentido do domínio das múltiplas linguagens, das ciências, da história da cidadania e da ética"133.

É interessante registrar que houve, de fato, uma reorganização estrutural da Diretoria de Orientação Técnica (DOT) ${ }^{34}$ para enfrentar o diagnóstico da prevalência de uma visão fragmentada do sistema educacional e do isolamento das unidades escolares. A escola é caracterizada como centro formador ${ }^{35}$.

32 Idem, p. 9.

33 São Paulo/SP, Secretaria Municipal de Educação, Caderno EducAção, n. 2, p. 4.

34 Antigo Departamento de Orientação Técnica, como já mencionado.

35 Cf. São Paulo/SP, Secretaria Municipal de Educação, Caderno EducAção, n. 2, p. 5. 


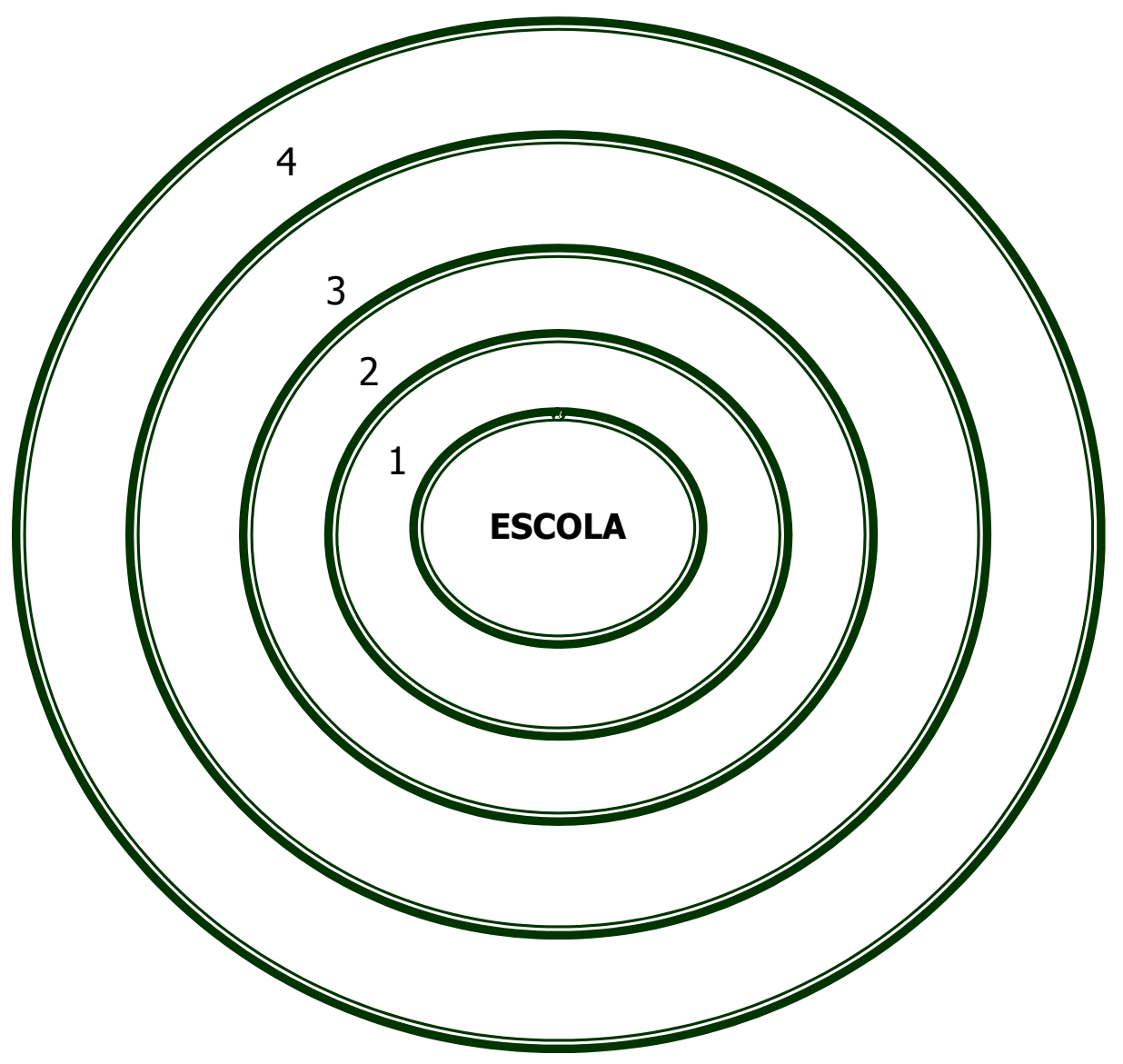

Do centro - escola - para a periferia tem-se, seguindo a ordem crescente de diâmetro:

1. Núcleos de Ação Educativa - NAEs, que representam a primeira instância de interlocução para organização do trabalho pedagógico. São treze no total, divididos por regiões de atendimento;

2. Níveis e Modalidades de Ensino, a saber, educação infantil, educação fundamental, educação de jovens e adultos e educação especial;

3. Projetos Especiais, Gestão, Multimeios e Múltiplas Linguagens e Formação Profissional;

4. Diretoria de Orientação Técnica - DOT.

A DOT, segundo o Caderno EducAção, tem como responsabilidade a elaboração, o planejamento, o acompanhamento e a avaliação da política pública pedagógica, criando condições e espaços para as contribuições dos NAEs e das escolas a partir das diretrizes administrativas. Sua estrutura organizacional é 
composta por grupos de trabalho: educação infantil, educação fundamental, educação de jovens e adultos/Mova, educação especial (inclusiva), gestão, multimeios e múltiplas linguagens, formação permanente/reorientação curricular, projetos especiais, pesquisa e intercâmbio cultural, tecnologias da informação e da comunicação ${ }^{36}$.

Cabe ressaltar que, no gráfico, não foi mencionada a educação inclusiva, mas no corpo do texto explicativo ela aparece ao lado e entre parênteses da educação especial, relacionando mais uma vez a primeira à referida modalidade de ensino.

A partir de diversos encontros entre coordenadores e representantes da equipe pedagógica, foram delineados como focos principais a discussão sobre Formação Permanente/Reorientação Curricular ${ }^{37}$. O grupo de trabalho formado em torno desse eixo teria como meta:

Reverter o isolamento em que se encontram as unidades possibilitando, no contexto territorial, a articulação entre escolas circunscritas em determinado espaço geográfico, comunidade e outras unidades da Administração Pública, para que a gestão e a autonomia se consolidem na perspectiva e uma rede de informações e comunicação, de acordo com as diretrizes da Secretaria Municipal de Educação ${ }^{38}$.

A operacionalização desse objetivo seria possível por meio da implantação dos GAAE - Grupos de Acompanhamento de Ação Educativa. As escolas, nos diferentes NAEs, são primeiramente agrupadas a cada cinco em um POLO, cujo critério é exclusivamente o de proximidade física. Os GAAE são formados por dois integrantes da Equipe Pedagógica do $\mathrm{NAE}^{39}$ (já alocados por POLO) e um membro da Universidade ${ }^{40}$, e se propunha a acompanhar o trabalho desenvolvido em cada escola

36 São Paulo/SP, Secretaria Municipal de Educação, Caderno EducAção, n. 2, p. 6.

37 Idem, ibidem.

38 Idem, p. 10.

39 Equipe Pedagógica do NAE: professores, coordenadores pedagógicos, diretores de escolas, supervisores escolares e assistentes técnico-educacionais.

40 São Paulo/SP, Secretaria Municipal de Educação, Caderno EducAção, n. 2, p. 7. "A participação da Universidade integrando os GAAE e também a assessoria aos POLOS se constitui, em um modo de fazer diferenciado, que valoriza e considera a inter-relação do conhecimento científico com os conhecimentos acumulados pelas escolas [...] assegurando o necessário e desejado diálogo". 
com encontros mensais, no mínimo.

Como se pode notar pelas responsabilidades dos membros do GAAE relacionadas abaixo, ficaria a cargo desses grupos a implantação da política pedagógica, em consonância com as diretrizes da Secretaria Municipal de Educação de São Paulo. São elas:

1. Planejar, acompanhar e avaliar, em consonância com as diretrizes de SME/DOT, a implantação da política pedagógica para a rede municipal de ensino;

2. promover contatos e encontros com a comunidade escolar para assessorar a elaboração do planejamento, acompanhamento e avaliação do Plano de Ação das Escolas;

3. problematizar e propor alternativas para a estrutura de funcionamento das Jornadas Especiais Integradas - JEI, possibilitando a troca de conhecimentos e experiências que reorientam o Projeto Político Pedagógico das escolas;

4. organizar reuniões nas escolas e nos pólos com integrantes dos GAAE para a troca de informações necessárias à comunicação e articulação dos pólos;

5. participar e propor encontros periódicos entre os NAEs e DOT para a formação e acompanhamento de demandas ${ }^{41}$.

Para a implementação dessa estrutura, ilustrada no que segue, foi feito um estudo preliminar que indicou a formação de 183 pólos com cinco unidades escolares (UE) cada. A intenção da gestão municipal era, por meio do agrupamento de escolas com situações geográficas e políticas assemelhadas, romper com o isolamento das unidades para que elas adquirissem maior potência de ação no enfrentamento dos desafios cotidianos. 


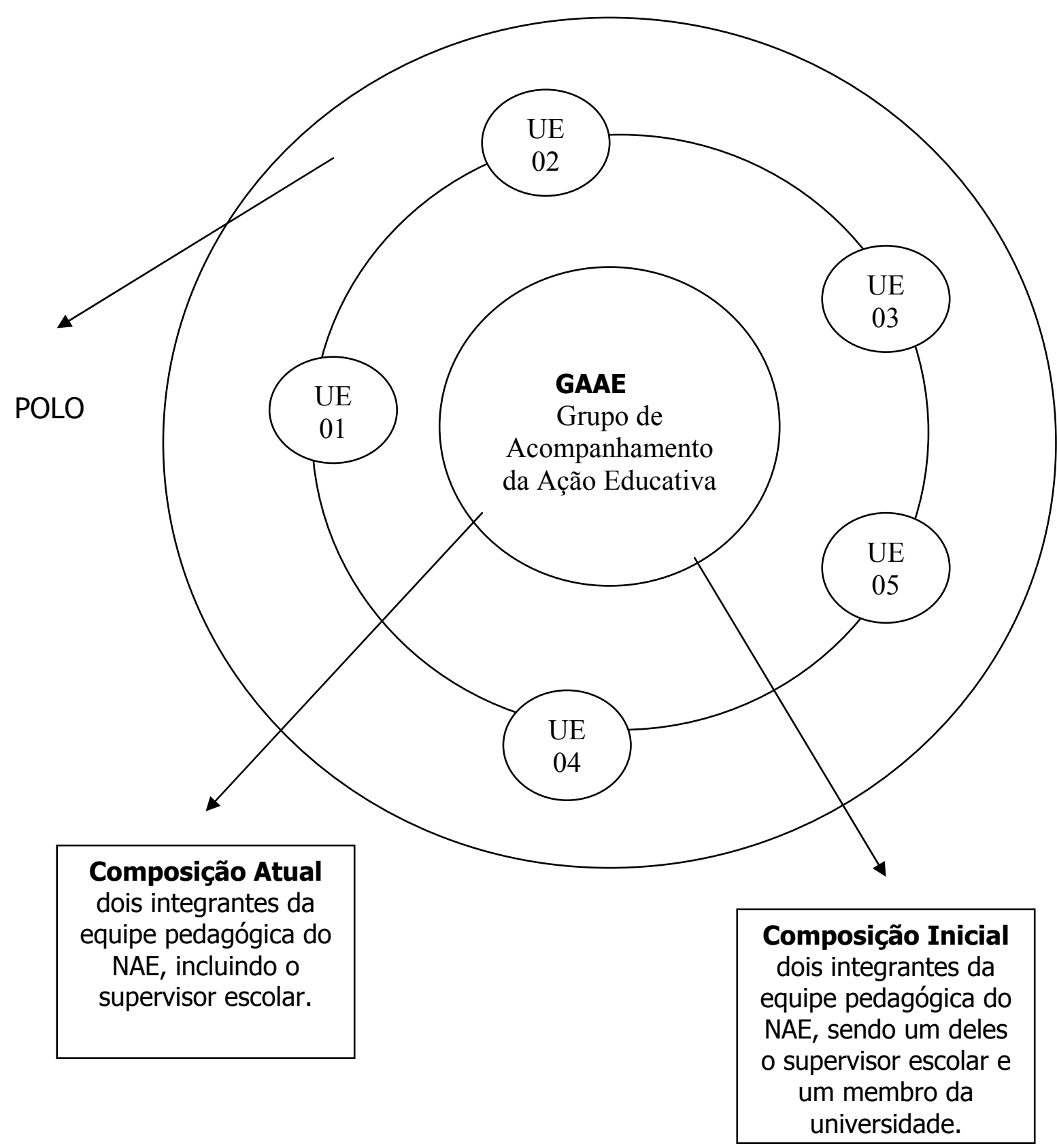

Seguindo a estruturação dessa célula, foi planejada a constituição de uma rede de formação e intercomunicação entre os vários pólos. Porém, segundo a própria dinâmica de rearticulação do horário de trabalho coletivo centrado nos Projetos Especiais de Ação, cada GAAE assumiu características diferenciadas, o que fez com que cada NAE fizesse propostas de acordo com as demandas que surgiam 
de suas escolas, desde que tivessem como norteadora a necessidade de concretizar as três diretrizes propostas por essa gestão da Secretaria Municipal de Educação.

Alguns ficaram como responsáveis pelo acompanhamento pedagógico da escola, imprimindo uma presença sistemática; outros optaram pela formação direta dos professores, por intermédio de ações promovidas pelo NAE com uma ação mais esparsa na escola; outros, ainda, adotaram projetos formativos com a contratação de professores universitários para discutir questões e temas levantados nos horários de trabalho coletivo.

O Núcleo de Ação Educativa 1242, ao qual a Escola Municipal de Ensino Fundamental Vianna Moog pertence, atendia um total de 44.681 alunos em suas 55 unidades escolares, cuja composição é de 25 Escolas Municipais de Educação Infantil - EMEIs, 29 Escolas Municipais de Ensino Fundamental - EMEFs e um Centro Municipal de Educação de Surdos - Cemes. Esse núcleo localiza-se no Caxingui e integra os distritos do Butantã, Itaim Bibi, Jaguaré, Jardim Paulista, Morumbi, Pinheiros, Raposo Tavares, Rio Pequeno e Vila Sônia. Para esse NAE foi indicada a estruturação de onze POLOS.

Com a divisão do Município em subprefeituras, instituída pela Lei 13.399 de $1^{\circ}$ de agosto de 2002 e regulamentada pela Portaria Intersecretarial das SMSP/SGM/SGP ${ }^{43}$ n. 6 de 2002, houve também uma nova reorganização da estrutura organizacional para a educação. Embora esse trabalho tenha sido desenvolvido sob a estrutura dos NAEs, cabe informar, no entanto, que foi criada uma Coordenadoria de Educação em cada subprefeitura. Nesta estão alocadas: a Seção de Informações Gerenciais, a Supervisão Escolar, a Diretoria de Orientação Técnico-Pedagógica DOT, a Diretoria Técnica de Planejamento, a Diretoria de Programas Especiais e as Unidades Escolares. A estrutura física do NAE 12 permaneceu intacta, mas houve um remanejamento de pessoal e uma readequação dos equipamentos, pois parte das escolas passaram a fazer parte de outras subprefeituras. Outra mudança importante deu-se em relação à gestão de recursos. A partir do momento em que a

42 O NAE 12 é o Núcleo de Ação Educativa ao qual pertence a escola Vianna Moog, locus do desenvolvimento desta pesquisa.

43 Secretaria Municipal das Subprefeituras/Secretaria de Governo Municipal/Secretaria de Gestão Pública. 
subprefeitura do Butantã foi criada, a Coordenadoria Educacional do Butantã - CEB ${ }^{44}$, na figura de seu coordenador, ficou com a responsabilidade de:

- emitir parecer conclusivo para a instância superior quando da celebração de parcerias e convênios para a prestação de serviços afetos à Coordenadoria e,

- assegurar o treinamento e desenvolvimento dos profissionais que compõe a Coordenadoria ${ }^{45}$.

Posto que é dentro dessa estrutura conjuntural de gestão municipal que a pesquisa foi realizada, é interessante, neste momento, retomar a explanação sobre as diretrizes municipais para a educação. Se o Caderno EducAção n. 1 primou por enfatizar as linhas gerais da gestão que iniciava, o Caderno EducAção n. 2 esclareceu a estrutura em que essas diretrizes seriam gestadas; o Caderno EducAção n. 3 teve como objetivo principal o entrelaçamento das duas propostas e a atualização das diretrizes como metas indissociáveis. Evidencia que a conceituação política de uma "educação inclusiva" que garanta o acesso ao conhecimento produzido socialmente pressupõe a garantia da permanência com qualidade objetivada em "construções, agasalhos, bolsas, inovações arquitetônicas, programas intersecretariais, transporte gratuito, provimento de materiais, ampliação de vagas, manutenção das escolas"46, que visariam não apenas a absorver a demanda, mas também a oferecer condições isonômicas de aprendizagem, assegurando a qualidade social da educação.

o Caderno EducAção n. 3 reafirma, ainda, que essa qualidade social da educação guarda uma relação estreita com a gestão democrática, pois a efetivação da cidadania se dá no

fortalecimento da auto-organização dos segmentos que integram a comunidade educacional, contribuindo para o fortalecimento de outras dimensões da democracia [...] não apenas a democracia representativa, mas, principalmente, a democracia participativa de modo a fortalecer e aperfeiçoar a construção de políticas, seu acompanhamento, a capacidade

44 Coordenadoria Educacional é a nova estrutura criada para gerir a educação, cujo vínculo é direto com a subprefeitura. Os Núcleos de Ação Educativa foram extintos nessa nova organização.

45 Portaria Intersecretarial 6/02, Criação das subprefeituras no município de São Paulo, item 3.2.5 subitens VI e VII.

46 Cf. São Paulo/SP, Secretaria Municipal de Educação, Caderno EducAção, n. 3, p. 13. 
de compreensão sobre financiamento e estrutura de orçamentos públicos e as próprias relações de representação ${ }^{47}$.

Nessa perspectiva de construção de relações horizontalizadas, enfatiza-se a necessidade de se trabalhar as relações entre os educadores dentro das escolas para o reconhecimento das diferenças e conflitos, no sentido de "criar a cultura da mudança", objetivando o desenvolvimento das potencialidades de todos para que possam agir como sujeitos de transformação de suas vidas, das de seus alunos e da sociedade como um todo ${ }^{48}$.

O Caderno EducAção n. 4 retoma todos os conceitos postulados nas publicações anteriores e avança na direção da consolidação das diretrizes. A qualidade social da educação é redefinida como uma articulação entre o debate com a sociedade e a formação permanente dos educadores, na perspectiva da ruptura do paradigma de multiplicadores de (in)formação ${ }^{49}$.

A realidade educacional na condição de interação de fatores complexos, internos e externos à mesma, requer uma leitura conjuntural para caracterizá-la. Antes, porém, de delinear o percurso da pesquisa na escola, e até para seguir o mesmo caminho que foi traçado na instituição, o próximo capítulo pretende, a partir dos conceitos de educação para todos e de educação inclusiva formulados de formas diferenciadas nos documentos legais e oficiais apresentados até agora, fazer uma revisão da bibliografia disponível sobre o assunto no sentido de aprofundar as discussões sobre essa temática.

47 São Paulo/SP, Secretaria Municipal de Educação, Caderno EducAção, n. 3, pp. 16 e 17. 48 Cf. Idem, pp. 17 e 18.

49 Cf. São Paulo/SP, Secretaria Municipal de Educação, Caderno EducAção, n. 4, pp. 5-35. 


\section{A DialÉTICA DA INCLUSÃo/EXCLUSÃo NUMA PERSPECTIVA SóCIO-HISTÓRICA}

A partir das proposições de educação para todos e de educação inclusiva formuladas de maneiras diferentes nos documentos legais e oficiais analisados até o momento, esse capítulo pretende desenvolver o conceito de inclusão.

Com o intuito de contribuir para a construção do conhecimento desse campo ${ }^{1}$, dentre a bibliografia disponível sobre o assunto, foram utilizadas obras de diversos autores que partilham de uma concepção dialética em relação aos conceitos de inclusão e exclusão, para além de uma definição que fique restrita aos aspectos educacionais.

Segundo os dicionários de filosofia consultados², o termo "dialética", por ser derivado de "diálogo", não tem apenas um significado unívoco, mas distintas acepções relacionadas entre si, não redutíveis umas às outras ou a uma definição comum.

A acepção a ser adotada neste trabalho diz respeito à "dialética como síntese dos opostos ${ }^{\prime \prime}$. Genericamente, trata-se do processo que resulta da disputa entre dois princípios, dois momentos ou duas atividades quaisquer. Segundo Lalande, Hegel aponta que a dialética é "da mesma natureza do pensamento" ${ }^{4}$, uma vez que a solução de contradições nas quais está constituída a realidade como tal é objeto do entendimento.

É importante conceituar dialética para entendê-la como dinâmica, e não como uma espécie de fórmula mágica que pode justificar tudo o que ocorreu no passado e o que se espera do futuro. Essa falsa aproximação com a noção de uma

1 A noção de campo é entendida como uma estenografia conceitual de um modo de construção do objeto que vai orientar todas as opções práticas da pesquisa. Ela funciona como um sinal que lembra que o objeto em questão não está isolado de um conjunto de relações. É necessário pensar o mundo social relacionalmente. Cf. Pierre BOURDIEU, O poder simbólico, 1989, pp. 23-34.

2 André LALANDE, Vocábulo técnico e crítico de filosofia; Nicola ABBAGNANO, Dicionário de filosofia e Walter BRUGGER, Dicionário de filosofia.

3 André LALANDE, op. cit., p.319.

4 Idem, ibidem. 
estrutura que "fagocita" todas as possíveis interpretações a respeito de determinado fenômeno sem considerar quais seus componentes históricos, num relativismo amorfo, contrapõe-se a uma efetiva discussão entre teses distintas. Essa construção social de hipóteses diferenciadas é imprescindível para formular uma crítica ao que está posto, e abrir caminho para o diálogo como embate entre postulados.

Na perspectiva dialética, a idéia de inclusão caracteriza-se como um processo que envolve o homem por inteiro e sua relação com os outros, e que determina e é determinada por formas de legitimação social e individual.

É processo sócio-histórico, que se configura [...] em todas as esferas da vida social, mas é vivido como [...] sentimentos, significados e ações 5 .

Os documentos considerados nos capítulos anteriores, de forma geral, procuram criar condições legais para que os direitos objetivados na Declaração Universal dos Direitos Humanos possam ser efetivados. Refletem um anseio comum, nos níveis mundial e local, quando apontam a necessidade da instauração de um movimento para a inclusão de todos nas várias esferas sociais, e mais precisamente na educação. A partir dessa afirmativa, pode-se concluir que, da forma como está organizada atualmente, a sociedade encerra características excludentes, e os direitos humanos, para serem efetivados, além de um ordenamento jurídico positivo ${ }^{6}$, carecem da defesa de sua legitimidade para seu reconhecimento. São, portanto, direitos que se gostaria de ter?.

Os direitos do homem, por mais fundamentais que sejam, são direitos históricos, ou seja, nascidos em certas circunstâncias, caracterizadas por lutas em defesa de novas liberdades contra velhos poderes, nascidos de modo gradual, não todos de uma vez nem de uma vez por todas ${ }^{8}$

Dado que os objetivos dos arcabouços legislativo e oficial é a idéia dos

5 Bader SAWAYA, "Introdução: exclusão ou inclusão perversa?", 2001, p. 8.

6 Segundo Bobbio, ordenamento jurídico positivo é o conjunto de normas válidas das quais faço parte como titular de direitos e deveres. Cf. Norberto BOBBIO, A era dos direitos, 1992, p. 15.

7 Cf. Idem, pp. 1-24.

8 Idem, p. 5. 
direitos humanos como inquestionável em seus fundamentos, a inclusão de todos é uma tese passível de ser postulada nesse momento histórico. Cabe, então, uma leitura conjuntural para delimitação de quais são as outras teses em jogo hoje na dialética da inclusão/exclusão, a fim de que se possa observar as possibilidades de ação para sua exeqüibilidade, principalmente no tocante à educação.

A forma de organização hegemônica da sociedade atual é o modo capitalista, que se caracteriza pela produção de mercadorias materialmente distintas, manifesta num conjunto correspondente de trabalhos úteis e diversos. Para exercê-los, é necessário uma divisão social dos homens, de modo que possam desempenhar as funções relativas à produção desses bens. As mercadorias são, portanto, a conjunção de dois fatores - matérias-primas diversas e trabalho qualitativa e quantitativamente distintos ${ }^{9}$. Essa diferenciação estruturante do capitalismo promove uma organização social correlata, que tem na desigualdade social um de seus postulados mais importantes. É na forma desigual que o homem vende sua força de trabalho empregada diferentemente na execução de mercadorias de diversos tipos, que se estabelece tanto nas relações econômicas como também nas relações sociais entre os sujeitos históricos. As mercadorias, como resultados finais do trabalho, encobrem as características sociais do mesmo. Sua transformação em valor agrega a elas atributos materiais e sociais como se fossem inerentes aos produtos. Assim, uma relação social estabelecida entre homens aparece, no mercado, como uma relação entre coisas $^{10}$.

Ainda que continue hegemônico, esse modo de produção vem sofrendo acomodações desde o seu momento inicial ${ }^{11}$. Sua versão mais atual, chamada de capitalismo neoliberal, pode ser caracterizada por uma série de estratégias políticas,

9 Cf. Karl MARX, O capital: crítica da economia política, livro 1, vol. I, parte primeira, pp. 41-93. 10 A este fenômeno Karl Marx chamou de fetichismo da mercadoria. A noção de valor é dada ao atributo material da mercadoria, sua matéria-prima. O valor-de-uso é estabelecido quando ao valor se agrega a força de trabalho do homem para sua transformação. Finalmente, o valor-de-troca aparece quando são estabelecidas relações entre as mercadorias. Precisamente neste momento, o valor do humano se submete ao da coisa, e o homem passa a trabalhar para a produção e a reprodução do sistema.

11 Cabe ressaltar que, ao caracterizá-lo como preeminente de determinado momento histórico, fica implícita a possibilidade da coexistência de outros discursos, em contraposição a uma idéia do processo admitido como natural, único, segundo a qual a própria idéia de mudança fica desprovida de significado e dá lugar à perspectiva de evolução, de progresso inevitável em uma dada direção. 
econômicas e jurídicas orientadas para adequar o modelo às novas condições sociais resultantes dos acontecimentos deflagrados pela implementação de um outro conjunto de regras anteriormente concebido para o enfrentamento de uma crise pregressa.

A crise situada nesta compreensão, não é algo conjuntural, passageiro e fortuito [...], mas elemento constitutivo e estrutural do capitalismo. Ciclicamente as crises se manifestam [...] e demandam uma recomposição dos interesses intercapitalistas e da própria classe trabalhadora ${ }^{12}$.

Cada momento de "crise" parece demandar uma série de medidas para sua superação. $O$ entendimento dessas etapas como históricas é condição para entender o processo, ao mesmo tempo em que configura qual objeto de disputa, pois seus desdobramentos práticos - a maneira de pensar e registrar o tempo - podem dar sentidos diversos ao trabalho com teses contraditórias: ruptura ou adequação aos limites da ordem estabelecida num dado momento ${ }^{13}$.

O entendimento dos postulados mais recentes, dessa feita, remete a uma breve análise do momento histórico anterior para delimitar as inter-relações entre as formas de reorganização encontradas e os apontamentos sobre o possível embate social com vistas à manutenção, ou não, do sistema capitalista.

O estabelecimento paulatino do chamado Estado de Bem-Estar Social, a partir dos sinais de crise na fase anterior do sistema capitalista, tinha como princípio uma outra divisão de responsabilidades entre o Estado e a livre iniciativa. Ao primeiro caberia garantir as condições gerais do funcionamento do modelo capitalista, inclusive algumas demandas por direitos políticos e sociais dos trabalhadores organizados, após a Segunda Guerra Mundial, por meio de seu poder regulador, controlador e interventor no planejamento econômico e social, principalmente em áreas entendidas como estratégicas para evitar que essas ficassem ao sabor do livre mercado. Pelo pagamento de impostos, a esfera pública seria responsável pela educação, saúde, transporte, lazer, habitação, que passam a

12 Gaudêncio FRIGOTTO, "A formação e a profissionalização do educador: novos desafios", p. 80.

13 Cf. Roberto LEHER, "Tempo, autonomia, sociedade civil e esfera pública: uma introdução ao debate a propósito dos "novos" movimentos sociais na educação", pp. 145-174. 
serem entendidos como direitos da população e deveres do Estado.

A justificativa desses valores ${ }^{14}$ não remete à consideração desses como inerentes ao homem ou como verdades evidentes em si mesmas, mas como fundamentos históricos, e, portanto, não absolutos, mas que podem ser factualmente comprovados ${ }^{15}$.

A aplicação dessas medidas gerou, ao longo do tempo, uma superprodução de mercadorias e a conseqüente dificuldade de seu escoamento. Promoveu, ainda, o acúmulo e a concentração exacerbados de capital financeiro. Esses dois fatores aliados passaram a dificultar o equilíbrio da equação que representava a manutenção do modo de produção capitalista: financiamento da produção e reprodução das condições gerais do sistema, manutenção dos direitos sociais adquiridos, e aumento do nível de acumulação ${ }^{16}$. Se o chamado fordismo ${ }^{17}$ tinha como principais características a rigidez produtiva e econômica, a centralidade política e a esfera pública comandando as relações sociais, sua crise advinda da superprodução de mercadorias e do acúmulo de capital financeiro impulsionou a uma reestruturação produtiva via mundialização do capital ${ }^{18}$.

A sobrevivência desse modelo pautado na produção e na circulação de mercadorias para a geração de lucro, dessa forma, exigiu novamente uma reestruturação política, econômica e jurídica para dar conta das novas demandas do sistema capitalista. A intervenção estatal julgada como perniciosa para o gozo da liberdade individual, base do pensamento liberal, foi elevada à máxima potência, pois todos os setores da vida social, inclusive aqueles que eram do domínio público estatal, ficariam sob a égide do mercado. Por seu ideário ser correlato ao do

14 Norberto BOBBIO, op. cit., 1992, p.27.

15 Em 1948, a assinatura da Declaração Universal dos Direitos Humanos pode ser acolhida como uma prova histórica sobre um consenso a respeito de determinado sistema de valores. A ONU contava, então, com 58 países-membros.

16 Dado que o foco do capitalismo é a geração de lucro, objetivado na produção e no comércio de mercadorias, é interessante notar que essa crise se instaura por conta da superprodução da mesma e não por dificuldades de produção.

17 O capitalismo fordista pode ser entendido como o tipo de organização das relações produtivas e sociais que antecedeu o capitalismo neoliberal, e que tinha como estratégia principal o estabelecimento do Estado de Bem-Estar Social, no sentido de deixar livre a iniciativa de investimento na produção de mercadorias em setores que fossem mais lucrativos.

18 Cf. João dos Reis SILVA JúNIOR, "Reformas educacionais, reconversão produtiva e a constituição de um novo sujeito", pp. 243-261. 
liberalismo, esse conjunto de medidas foi nomeada de neoliberal. A diferença residia no fato de que, enquanto a proposta liberal anterior defendia a universalização da cidadania, entendida como a liberdade e a igualdade formais de todos diante do Estado, no neoliberalismo, a igualdade é mediada pelo mercado - no qual o Estado não deve interferir - que a confere segundo as habilidades e competências de cada $u^{19}$.

Segundo Friedrich Hayek, um dos mais famosos teóricos do neoliberalismo ${ }^{20}$, se o homem comum não afirma na sua vida cotidiana o valor da competição, se a sociedade não aceita as enormes possibilidades modernizadoras que o mercado oferece quando pode atuar sem a prejudicial interferência do Estado, as conseqüências são nefastas para a própria democracia ${ }^{21}$ : os piores serão os primeiros, o totalitarismo aumentará e a planificação centralizada tomará conta da vida das pessoas, impedindo-Ihes de expressar seus desejos individuais, sua vocação de melhora contínua, sua liberdade de escolher.

A proposta neoliberal baseada na diminuição da atuação e do custo do Estado e na ampliação dos campos de ação da livre iniciativa, preconiza a disseminação de uma nova forma de organização das corporações em nível mundial com base na desnacionalização, na transformação da estrutura do mercado de trabalho via terceirização, na precarização das relações trabalhistas e na conseqüente fragilização dos direitos sociais como saída para a crise do sistema.

A "nação" hoje, visivelmente, está em vias de perder uma parte importante
de suas velhas funções, nominalmente aquela de constituição de uma
economia nacional. [...] Especialmente desde os anos 60 o papel das
"economias" nacionais tem sido corroído ou mesmo colocado em questão

19 Cf. Roberto LEHER, op. cit., pp. 145-174.

20 Cf. Friedrich HAYEK, Camino de servindubre, 1990, pp. 103-135.

21 Cf. Norberto BOBBIO, O futuro da democracia, 2000, p. XX, a definição de democracia moderna está relacionada com o surgimento dos Estados Nacionais e dos direitos humanos como limitadores deste poder. Assim, o Estado liberal é pressuposto histórico e jurídico do Estado democrático. Um acordo mínimo quando se fala em democracia, em contraposição às formas de governo autocráticas, é o de considerá-la caracterizada por um conjunto de regras que estabelece quem está autorizado a tomar decisões coletivas e com quais procedimentos. Além disso, é preciso que aqueles que são chamados a decidir sejam colocados diante de alternativas reais e postos em condição de poder escolher entre uma e outra. Como a postulação dos direitos humanos é a de que todos devem ser reconhecidos como cidadãos, todos, a princípio, podem ser designados para tomar estas decisões coletivas. 
pelas principais transformações na divisão internacional do trabalho, cujas unidades básicas são organizações de todos os tamanhos, multinacionais ou transnacionais e redes de transações econômicas, que estão, para fins práticos, fora do controle dos governos e estados ${ }^{22}$.

A divisão internacional do trabalho, implementada via globalização ${ }^{23}$, estabeleceu a chamada competividade intercapitalista, ou seja, entre os Estados Nacionais capitalistas, promovendo o aprofundamento das diferenças entre os paises desenvolvidos e os países dependentes que, pela impossibilidade de acompanhar o desenvolvimento tecnológico, sofreram o desmonte de seus parques industriais. Esses fatores conjuntos determinaram o fechamento de milhares de postos de trabalho, o que elevou exacerbadamente as taxas de desemprego, agora entendido como estrutural e condição básica para a reprodução capitalista. Ou seja, a mundialização da economia conferiu um caráter de centralidade às políticas neoliberais, o que possibilitou perceber, no nível mundial, o agravamento da desigualdade social. O Estado passa a ser fomentador de um conjunto de valores mercadológicos, em que a flexibilidade e a competitividade são baluartes. A privatização da esfera pública representa, ao mesmo tempo, uma forma de enxugar o Estado e uma resposta aos anseios sociais frente à paulatina desresponsabilidade desse por setores que eram públicos estatais. A implementação de relações de parceria público-privada têm a mesma lógica de geração de lucro, inaugurando experiências de modos autônomos de prestação de serviços nas esferas intergovernamentais da gestão de políticas públicas ${ }^{24}$.

O estabelecimento do Estado Nacional Mínimo ${ }^{25}$ implicou, assim, o retraimento da esfera pública como responsável pela viabilização dos direitos sociais. Seu poder centralizador, originário de sua forma estrutural anterior - Estado de Bem-

22 Eric HOBSBAWM, "Nações e nacionalismo desde 1780", 1990, p. 206.

23 A globalização está sendo entendida como estratégia para a concretização do capitalismo neoliberal no sentido de minimizar o controle dos Estados Nacionais.

24 Cf. Maria da Glória M. GOHN, "Educação, trabalho e lutas sociais", pp. 89-107.

25 Os Estados Nacionais passaram a não mais deter o monopólio da regulação de setores anteriormente entendidos como prioritários e estratégicos como a educação, saúde, transportes, comunicações, infra-estrutura, que passaram a ser regulados pelo mercado. A este Estado que passou a ter uma atuação de articulador desta reestruturação produtiva, com ações restritas e de caráter minimamente intervencionista deu-se o nome de Estado Mínimo. 
Estar Social - volta-se para a execução de atividades basicamente avaliadoras e gerenciadoras dos resultados e efeitos de tal reestruturação, objetivadas na criação de paliativos sociais e formas assistencialistas para parcelas cada vez maiores da população. O desemprego, por exemplo, tem sido alvo constante de mecanismos estatais de gestão que, levando a cabo a premissa não intervencionista liberal, administra a questão sem, no entanto, preocupar-se em enfrentar seus fatores causais.

Ao se colocar em xeque a viabilidade de uma proposta consensuada de sociedade pautada em direitos sociais e deveres do Estado e ao se postular uma sociedade em que todas as relações são mediadas pelo mercado, estabelece-se uma crise, não exclusiva do sistema de produção, mas de caráter ético-político, que marca um momento de sobreposição do capital sobre o trabalho, da mercadoria sobre a sociedade que a produz. A desigualdade social se objetiva na diferença entre os altos níveis de acumulação e riqueza socialmente produzida e sua distribuição cada vez mais díspar. Apesar de as explicações para a exacerbação desse fenômeno terem como argumentos centrais a ineficiência, a ineficácia, a improdutividade e o desajuste como causas das crises, principalmente nos países dependentes, não se trata de um fenômeno local ou individual, embora seus efeitos possam ser observados nos diversos âmbitos.

Há uma pressão sobre os direitos sociais no sentido de estes se tornarem mercadorias negociáveis no mercado como qualquer outro bem ou serviço, cuja qualidade é variável na direta proporção do poder aquisitivo de quem compra. A educação não é exceção, mesmo estando consensuada e formalizada no artigo $26^{\circ}$ da Declaração Universal dos Direitos Humanos, e tem sido alvo de redimensionamento a título de adequação à reestruturação produtiva.

É de fato tentador considerá-la como um fenômeno local e sem conexão com as questões principais do século [XX] [...]. Se isto fosse verdadeiro, contudo, a crise no nosso sistema escolar não se teria tornado um problema político e as autoridades educacionais não teriam sido incapazes de lidar com ela a tempo ${ }^{26}$.

26 Hanna ARENDT, Entre o passado e o futuro, 2001, p. 222. 
As reformas governamentais podem ser entendidas como instrumentos administrativos de ajuste que têm como bases: a restrição e a desregulamentação da esfera pública e o proporcional alargamento da esfera privada, cujo objetivo é reestruturar o processo educativo em razão das demandas da produção do capital e provocar as transformações educacionais necessárias ${ }^{27}$.

A descentralização é uma medida inscrita na lógica da autonomia ${ }^{28}$. Em um primeiro momento, as responsabilidades da União são repassadas para os Estados e Municípios, a pretexto de aproximar a gestão da verba da população usuária. 0 Governo Federal abre mão de funções que eram direta ou indiretamente de sua alçada, como a educação básica, mas permanece estabelecendo diretrizes gerais, avaliando e distribuindo verbas. O mote da reforma educacional seria o fortalecimento e o aumento das condições de empregos, cujos pilares seriam a competência ${ }^{29}$ e a empregabilidade. Essas duas diretrizes globais transformariam a escola num instrumento de "democratização", num mercado de escolhas e oportunidades "iguais" para todos. A sensação da possibilidade de emprego aliada à competência adquirida por meio da qualificação permearia todas as relações na e com a escola. Dessa forma, a educação passa a transitar entre a esfera do direito social e a da possibilidade individual de inclusão social. Os processos educacionais devem, então, acionar todas as formas de conhecimento como recursos importantes para a entrada no mundo do trabalho, retomando a idéia de que a formação profissional é estratégica para que um país se desenvolva.

Esse discurso, quando confrontado com o quadro social de desemprego como explicitado acima, torna-se incoerente e faz parecer uma explicação simplista e particularizada para algo que é muito mais amplo. Numa sociedade em que a

27 Cf. João dos Reis SILVA JÚNIOR, op. cit., pp. 243-261.

28 A autonomia defendida pelos teóricos do neoliberalismo é equivalente à soberania do individuo no mercado. Toda interferência externa é vista como produtora de perturbações que estariam na origem dos desequilíbrios econômicos do presente, cf. Roberto LEHER, op. cit., pp. 145-174.

290 conceito de competência é uma construção social mais complexa que o conceito de qualificação, pois se descola das instituições formais e da experiência adquirida e passa a considerar aspectos pessoais e disposições subjetivas como fatores importantes no mundo do trabalho, cf. Vanilda PAIVA, "Qualificação, crise do trabalho assalariado e exclusão social", pp. 49-62. 
competição é intensificada e há uma clara diminuição dos postos de trabalho como decorrência da reestruturação do mercado de trabalho, o reordenamento social das profissões, associado a um crescente esvaziamento do status profissional e a uma queda considerável dos salários, são fatores estruturais que não podem deixar de ser considerados dada a sua relevância.

As medidas neoliberais em torno da educação, cujo objetivo é a mercantilização da mesma, têm categorizado diversos tipos de "educação". Para a população de baixa renda, a prioridade remete apenas à educação rudimentar, minimalista, definida como parte de uma política assistencialista, capaz de "aliviar" a pobreza para garantir adequada governabilidade.

A escola vista pelos tecnocratas é mero instrumento que tem na burocratização do trabalho escolar e na fragmentação do conhecimento fatores centrais para a manutenção do sistema capitalista de produção. A crise nas instituições escolares, segundo esse enfoque, é uma crise gerencial, que, de forma semelhante à crise do Estado, pode ser "combatida" com medidas administrativas: tornar as práticas pedagógicas mais eficientes e requalificar o professor na "nova" função social da escola. A competitividade entre as escolas públicas e dessas com as escolas privadas dentro de um mercado "livre" é o que impulsionaria esses estabelecimentos rumo à qualidade total. Esse esforço seria avaliado por comissões externas por meio de provas estandartizadas, e, portanto, supostamente idôneas, que possibilitariam um "ranquiamento" no sentido de mostrar para a sociedade qual é o melhor serviço educacional oferecido no mercado e qual seu custo. Dentro da sala de aula, a aprendizagem adquiriu um sentido individualista e adaptativo, o que delegou à educação a posição de instrumento de aquisição de saberes para competir e conseguir um lugar no mercado de trabalho. O conhecimento é, portanto, eficaz quando utilizado contra o outro, quando ajuda a deixar os outros para trás, ou seja, um fator de diferenciação e de poder.

Nesse sentido, a noção de cidadania é reconceituada e denota a possibilidade de ação do indivíduo como proprietário e consumidor, inclusive de educação. Como já mencionado, há uma outra noção de cidadania que se caracteriza pela concepção universal e universalizante dos direitos humanos. Nas palavras de 
Bobbio, "a democracia é a sociedade dos cidadãos, e os súditos se tornam cidadãos quando Ihes são reconhecidos alguns direitos fundamentais" ${ }^{\prime 30}$.

Como vem sendo descrito, para a instauração do modelo capitalista neoliberal como hegemônico é condição necessária, mas não suficiente, o estabelecimento de uma série de estratégias políticas, econômicas e sociais. Há, concomitantemente, a implementação de um projeto de reforma ideológica da sociedade, empenhado na construção de um novo senso comum que resultaria numa única forma legítima de pensar a realidade econômico-social.

Uma de suas táticas seria justamente a reformulação de conceitos como cidadania, democracia, direito, qualidade, formação, ética e igualdade, que outrora se relacionavam com os direitos sociais e humanos, tomando-os como princípios regidos pelo mercado. É precisamente no embate entre os conceitos postulados anteriormente e sua reorganização nos discursos neoliberais que as teses ficam mais nítidas e passíveis de diferenciação, escondidas por vezes num pretenso consenso retórico. Outrossim, pelo princípio da dialética, há o reconhecimento que os valores sociais mudam historicamente. Porém, isto não quer dizer que esses sejam passíveis de relativismo.

O Estado Moderno, em sua versão liberal, busca garantir as liberdades individuais e políticas e os direitos sociais. O neoliberalismo, como novo modelo, tem o mercado como mediador de todas as relações sociais e redimensiona os direitos sociais, civis, públicos e políticos como subalternos a ele.

As questões ético-políticas são colocadas como econômicas e passam a ser entendidas como questões técnicas cuja resolução está na mão de especialistas que detêm um receituário formulado para a adequação de cada problema que aparece.

É oportuno lembrar que, no capitalismo, são valores básicos, entre outros, o individualismo, o lucro e a competição, em que a racionalidade da máxima "os fins justificam os meios" impõe como tônica a aceitação da desigualdade. Todavia, não

convém que tal iniqüidade seja desvelada, por isso há todo um esforço em postular uma nova conceituação para valores socialmente consensuados. A

30 Norberto BOBBIO, op. cit., 1992, p. 1. 
democracia adquire um caráter meritocrático segundo o qual os "melhores" cidadãos tomam as decisões pelo coletivo da sociedade com base no que é o possível e cabível ao modelo. Separa-se, assim, a noção de democracia da de igualdade. "Ela é, simplesmente, um sistema político que deve permitir aos indivíduos desenvolver sua inesgotável capacidade de livre escolha na única esfera que garante e potencializa a referida capacidade individual: o mercado"31.

Para ser admitido como único discurso possível, faz-se necessário admitir-se como pressuposto a ausência de conflitos, isto é, de que o funcionamento do sistema social é harmônico.

\begin{abstract}
A aversão ao conflito exige que a ideologia dominante impute ao Estado a tarefa de funcionar como árbitro da sociedade como um todo, motivo pelo qual ele tem que aparecer como aquele que paira acima das classes sociais. Nesse sentido, qualquer iniciativa de intervenção de países do bloco dominante nos países periféricos deve carregar consigo a aura de ajuda e, para que tal intento seja bem-sucedido, é necessário então deshistoricizar, despolitizar e descontextualizar os processos. É assim que tal ajuda se traveste de um matiz "solidário", camuflando a vinculação econômica e política subjacente que, de fato, a caracteriza. [...] Dessa forma fica fácil entender porque os discursos dominantes seduzem pela generalidade, sobretudo quando acenam com o propósito de modernizar as sociedades e de construir a cidadania, essa aqui entendida tão somente enquanto mecanismo produtor de consumidores ${ }^{32}$.
\end{abstract}

A transformação da realidade permeia, dessa forma, o clareamento dos discursos, sua diferenciação para que um dos princípios democráticos possa ser estabelecido: que aqueles que são chamados a decidir sejam colocados diante de alternativas reais e postos em condição de poder escolher entre uma e outra. Como a postulação dos direitos humanos é a de que todos devem ser reconhecidos como cidadãos, todos, a princípio, deveriam ter claras quais são as teses em jogo, pois poderiam ser designados a tomar essas decisões coletivas ou, numa outra hipótese, exerceriam controle social sobre seus representantes.

31 Pablo GENTILI e Tomás Tadeu da SILVA, Escola S.A.: quem ganha e quem perde no mercado educacional do neoliberalismo, 1996, p. 20.

32 César Augusto MINTO, op. cit. , pp. 156-157. 
O discurso neoliberal pode ser descrito como um discurso pasteurizado ${ }^{33}$, pois se aproveita de determinados conceitos frutos de consenso social e os subverte, ora apenas tentando impor por meio da camuflagem do que efetivamente quer expressar, ora tentando abarcar todas as correlações de forças no momento, dando uma falsa idéia de consenso e de não-conflito. Esse tipo de discurso, por emergir de situações conflituosas, mas negociadas, pode impossibilitar o embate democrático, pois contém em seus argumentos partes dos vários discursos que se apresentam.

\begin{abstract}
Este tipo de discurso pasteurizado viabiliza outros enfrentamentos legais e, com isto, novas chances de rever equívocos, por exemplo. São também indicadores - sobretudo nas leis e nos documentos oficiais - de disputas de poder e, portanto, de resistências pendentes, de contradições - mais, ou menos - evidentes ${ }^{34}$.
\end{abstract}

Essas considerações são importantes para que haja o compartilhamento de algumas noções como, por exemplo, a inviabilidade da análise educacional sem, ao menos, uma breve avaliação da conjuntura social da qual ela é parte, pois a própria caracterização da mesma é derivada desse entendimento. Pôde-se perceber, pela análise anterior do sistema capitalista de produção, que a tese neoliberal revela-se a partir de estratégias que podem ser de caráter mais objetivo e outras de cunho mais subjetivo. Este entrelaçamento entre as duas perspectivas é condição para o estudo da idéia de inclusão/exclusão sob o ponto de vista da dialética e como um processo que envolve o homem por inteiro em sua relação com os outros e que determina e é determinada por formas de legitimação social e individual.

Esta concepção (dialética de exclusão/inclusão) introduz a ética e a subjetividade na análise sociológica da desigualdade, ampliando as interpretações legalistas e minimalistas de inclusão como as baseadas na justiça social e restrita à crise do Estado e do sistema de empregabilidade. Dessa forma, exclusão passa a ser entendida como descompromisso político com o sofrimento do outro ${ }^{35}$.

33 Cf. Idem, pp. 144-152.

34 Idem, pp. 160.

35 Bader SAWAYA, op. cit., p. 8. 
Segundo Sposatti, a exclusão atualmente deve ser entendida como uma vivência de privação e abandono de uma parcela significativa da população, revelando seu caráter social.

Não se trata de um processo individual, embora atinja as pessoas, mas, de uma lógica presente nas relações econômicas, culturais e políticas da sociedade brasileira. [...] Esta situação de privação coletiva é que se está entendendo por exclusão social. Ela inclui a pobreza, discriminação, subalternidade, não equidade, não acessibilidade, não representação pública. É portanto, um processo múltiplo que se explica por várias situações de privação da autonomia, do desenvolvimento humano, da qualidade de vida, da equidade e da desigualdade ${ }^{36}$.

A exclusão contemporânea, diferentemente das formas anteriores, pode ser caracterizada pela desnecessidade de grande parte da população mundial para a efetivação e a sustentação do modo de produção capitalista. $O$ entendimento do fenômeno da desigualdade social como regra básica do jogo capitalista promove, assim, seu reforço e reprodução, tanto no nível social como individual. Para a sobrevivência do sistema de circulação de mercadorias, constrói-se a idéia de que é natural a exclusão de grandes parcelas da população que não se "adequam" a esse princípio. Esse trabalho tem funcionado como uma espécie de gota-a-gota simbólico que estabelece com a mídia uma parceria eficaz como mecanismo de controle (o quarto poder), para criar e afirmar padrões estéticos e valores, definir comportamentos, dando uma "falsa" unicidade ao discurso preponderante ${ }^{37}$.

A não utilização ou a sub-utilização de mão-de-obra capacitada promove a construção da idéia de uma sociedade de excluídos e precarizados, que, postos no mesmo nível de mercadorias, possibilitam a postulação de uma sociedade do descartável. A fórmula anti-social, que tem na competitividade exacerbada sua justificativa, permite que haja uma internalização de que aquele que não consegue viver com dignidade é incapaz e/ou inadaptado. De modo semelhante à teoria darwiniana, são os melhores e os mais competentes que conseguem encontrar seu lugar no mundo, dando um caráter natural para a desigualdade social que passa a

36 Aldaíza SPOSATTI, Mapa da exclusão/inclusão social na cidade de São Paulo, 1996, p. 13.

37 Cf. Pierre BOURDIEU, Contrafogos: táticas para enfrentar a invasão neoliberal, 1998, pp. 42-61. 
ser atribuída à diferença entre capacidades individuais, e, ao mesmo tempo, divinizando o mercado.

Na sociedade capitalista, porém, a exclusão é parte do movimento de sua regra estruturante: exclui para depois incluir de outro modo, segundo a lógica do mercado.

\begin{abstract}
A sociedade moderna está criando uma grande massa de população sobrante, que tem pouca chance, de fato, de ser incluída nos padrões atuais de desenvolvimento econômico. Em outras palavras, o período da passagem do momento de exclusão para o de inclusão está se transformando num modo de vida, está se tornando mais do que um período transitório ${ }^{38}$.
\end{abstract}

O excluído hoje tem acesso ao mercado consumidor, principalmente por meio do consumismo dirigido, o que possibilita que adquira um tipo de produto condizente com seu poder de compra. A aquisição dessas mercadorias cujo valor é extremamente diferente, mas que são semelhantes na aparência, pois são imitações mais baratas e, portanto, mais acessíveis, admite a construção de um sujeito de segunda classe que imita os ricos partilhando não apenas mercadorias semelhantes, mas também idéias individualistas e competitivas. É aquele, que além de estar em situação de carência material, não é reconhecido como sujeito de primeira linha, pois não reconhece a si como tal e não atua como tal.

Essa inclusão marginal ${ }^{39}$, em que os sujeitos estão a serviço de processos econômicos, objetivados na produção e circulação de mercadorias e restritos em termos do que é necessário e conveniente para a mais eficaz reprodução do capital, produz uma idéia potencial de igualdade frente ao mercado que aparece semelhante à antiga figura da justiça cega que se propõe da mesma forma para todos. Porém, se as oportunidades não são iguais, o valor dos bens é diferente e a ascensão social é caracterizada pelo aumento qualitativo e quantitativo do grau de consumo, a imitação e a reprodução, mesmo que baratas, tomam paulatinamente o lugar da produção e da criação e promovem a fragilização dos vínculos sociais. O processo de

38 José de Souza MARTINS, Exclusão social e a nova desigualdade, 1997, p. 33.

39 Cf. Idem, pp. 25-38. 
inclusão precária cria uma sociedade paralela que é inclusiva do ponto de vista econômico, dado que todos buscam no mercado uma forma de sobrevivência, e excludente do ponto de vista social, moral e político. Os sujeitos nessa situação passam a desconfiar de si próprios, numa culpabilidade popular.

Caminhando sobre o chão pavimentado pelo preconceito dos pobres contra os pobres, as classes dominantes no Brasil começaram a extravasar uma subjetividade antipública que segrega, elabora pela comunicação mediática uma ideologia antiestatal ${ }^{40}$.

O sentimento de inclusão pela participação na esfera do consumo faz com que o discurso da sobreposição do mercado ao Estado, da desnecessidade do público, da proteção social vista como custo que deve ser eliminado para possibilitar uma concorrência mais efetiva, seja disseminado e repetido por toda a sociedade, inclusive por aqueles que, ao não terem assegurados os direitos sociais como dever do Estado, não têm possibilidade de participar efetivamente dos processos de decisão ético-política sobre a natureza da sociedade que está sendo construída, tornando-se porta-vozes de um discurso que deslegitima sua própria consideração.

Retomando o conceito de cidadania exposto anteriormente, se a democracia é a sociedade dos cidadãos, e se os súditos se tornam cidadãos quando Ihes são reconhecidos alguns direitos fundamentais, pode-se dizer que o capitalismo neoliberal é um regime que se aproxima muito do totalitarismo do mercado.

A idéia de liberdade mercadológica legitima a idéia de que os excluídos são culpados por sua incompetência, uma vez que todos podem ser incluídos. Essa visão não permite o estabelecimento de classes antagônicas com pensamentos opostos, mas um pensamento unificado que constrói subjetividades que não se reconhecem como cidadãos e, portanto, não atuam como tal, por seu próprio demérito.

Desse conjunto de afirmações, fica claro que, para essa situação ser reproduzida, não basta uma análise das condições materiais e objetivas da sociedade, mas também qual sua imbricação com os fatores de legitimação

40 Francisco de OLIVEIRA, Vanguarda do atraso e atraso da vanguarda: globalização e neoliberalismo na América Latina, 1997, p. 15. 
individual. Podem ser destacados dois aspectos psicossociais ideológicos que foram citados ao longo de nosso percurso e que são fundamentais para a compreensão desse ângulo de análise: a competitividade e a culpabilização.

A competitividade é um pressuposto do capitalismo neoliberal e uma condição sine qua non para seu progresso e desenvolvimento. É justamente o confronto entre os interesses individuais que faz com que as pessoas lutem, trabalhem e se esforcem para conseguir melhorar sua qualidade de vida e obter ascensão econômica. A competitividade, como uma "seleção natural" estabelecida, é posta como a única forma de sobreviver, o que torna natural a exclusão de alguns para o privilegiamento de outros, contribuindo para o agravamento da polarização entre ricos e pobres, inclusive na relação entre países. Naturaliza-se a idéia de que os "piores" dêem lugar para os "melhores". Cabe aos primeiros serem "bons o suficiente" para acharem seu lugar no mercado, pois há lugar para todos aqueles que se esforçam.

Por outro lado, os procedimentos de produção estão cada vez mais individualizados e fragmentados, ao passo que a terceirização de etapas do trabalho uniformiza as relações de compra e venda de mão-de-obra - "Você S.A.". Cada sujeito tem o entendimento que pode concorrer livremente, colocando à disposição as mercadorias ou os serviços que detém. A superexploração dos trabalhadores, ininterruptamente postulada nos conceitos de flexibilização e precarização, promove um clima de indiferença anti-solidária e a fabricação de uma multidão de seres humanos empobrecidos e descartáveis, pela falta de relações intersubjetivas e pela noção adquirida da insignificância individual frente ao sistema.

A atribuição do sucesso e do fracasso exclusivamente a sujeitos particulares, deixando-se de lado as causalidades histórico-sociais e o endeusamento do individual produzem um efeito de culpa que dificulta uma reflexão a respeito das responsabilidades no nível macro. Os espaços coletivos são utilizados de forma também individual, e o que é preconizado é que cada um deve fazer sua parte em detrimento de um projeto que opte por ações coletivas.

A desigualdade social pode ser entendida como a dimensão objetiva da dialética da exclusão/inclusão. Sua parte subjetiva refere-se ao sofrimento individual, 
a culpa sentida por sua própria situação de excluído e a consequente fragilização dos vínculos sociais.

O sofrimento ético-político qualifica-se pela maneira como se estabelecem as relações na intersubjetividade, cuja dinâmica, conteúdo e qualidade são determinados pela organização social.

Retrata a vivência das questões sociais dominantes em cada época histórica, especialmente a dor que surge da situação social de ser tratado como inferior, subalterno, sem valor, apêndice inútil da sociedade. Ela revela a tonalidade ética da vivência cotidiana da desigualdade social, da negação imposta socialmente às possibilidades da maioria apropriar-se da produção material, cultural e social de sua época, de se movimentar no espaço público e da expressar desejo e afeto ${ }^{41}$.

Subjacente à inclusão pela relação igualitária com o mercado, a desigualdade social se faz presente no cotidiano das relações humanas. Ao admitir-se que as relações sociais estão recobertas pela ordem e pela dominação, é preciso, então, fortalecê-las, utilizando duas estratégias, como o próprio neoliberalismo: uma de ordem material e jurídica, e outra de ordem afetiva e intersubjetiva.

Nessa perspectiva, a práxis psicossocial, quer em comunidades, empresas ou escolas, deve preocupar-se com o fortalecimento da legitimidade social [...] pelo exercício da legitimidade individual, alimentando "bons encontros", com profundidade emocional e continuidade no tempo, mas atuando no presente. A preocupação com a afetividade leva o psicólogo social a encarar o presente como tempo fundante da exclusão, recusando o paradigma da redenção [...] que remete ao futuro a realização dos desejos e da justiça social ${ }^{42}$.

A derrubada da fronteira entre o bem coletivo e a felicidade individual está no cerne dessa perspectiva. O alargamento do campo de ação individual se dá, justamente, quando da união da coletividade organizada em prol de benefícios relevantes a todos, com o fortalecimento dos vínculos sociais.

A busca de "bons encontros" como norte para as ações humanas tem, nas

41 Bader SAWAYA, $O$ sofrimento ético-político como categoria de análise da dialética exclusão/inclusão, 2001, p. 105.

42 Idem, p. 115. 
instituições sociais, seu lugar privilegiado para ocorrer. O papel da escola, como tal, merece uma análise mais detalhada no sentido de tornar perceptível o movimento oscilatório de pelo menos duas teses principais presentes em seu cotidiano: a força mantenedora e o poder transformador.

O modelo neoliberal, como já descrito, busca formalizar uma idéia única de sociedade no nível global, que tem no mercado a interlocutor central para o estabelecimento das relações. A noção de "Estado Mínimo" remete à não-intervenção e transforma sua função de responsabilidade social numa função gerencial, que dá diretrizes e avalia seu cumprimento via estandartização, via ISO (International Standart Organization), o que tem possibilitado o ranquiamento e a competição entre os países, instituições sociais e sujeitos.

No caso da educação, seu entendimento como direito social tem dado lugar a uma visão de necessidade para adaptação social, tanto no nível dos países como possibilidade de desenvolvimento, como no nível individual como forma de inclusão social. A idéia de uma fórmula pré-moldada acaba por gerar vínculos sociais frágeis, posto que as possibilidades de ação são estereotipadas e previamente estruturadas para que, ao mesmo tempo, dêem conta dos anseios por uma sociedade mais justa pelo menos no plano do discurso - e mantenham a sociedade do jeito como ela está. O discurso "natural" busca canalizar as ações de cada indivíduo para a execução dessas receitas pré-moldadas e o vínculo aparece como dado mercadológico e não como construção social. Por exemplo, aumentar a lista de contatos, conhecer pessoas interessantes, adquirir mais conhecimento são formas de ampliar os horizontes de compra e venda de mão-de-obra ou serviços.

A educação, na perspectiva de bem ou serviço que pode ser adquirido no mercado, pode ser diferenciada de acordo com o público-alvo, com o cliente ao qual se destina. Dessa forma, pode ser um instrumento poderoso de validação desse sistema, pois reproduz a desigualdade social. Para ilustrar o discurso de que 0 desempenho escolar é chave na manutenção e reprodução do sistema hegemônico, Bourdieu postula que este modela subjetividades, ao mesmo tempo em que justifica o porquê do locus social ocupado pelo sujeito. A esse fenômeno chamou de "teodicéia dos privilégios": 
Na miséria dos excluídos do trabalho, na miséria dos desempregados crônicos, há algo mais que no passado... A justificação ética foi substituída pela intelectual. Os pobres não são apenas imorais, alcoólatras, corrompidos, são estúpidos, pouco inteligentes. Para o sofrimento social, contribui em grande medida a miséria do desempenho escolar que não determina apenas os destinos sociais, mas também a imagem que estas pessoas fazem deste destino ${ }^{43}$.

A opção do governo federal no Brasil pela ampliação do número de vagas por meio da iniciativa privada é um aspecto que pode ser destacado como exemplo da transferência paulatina de responsabilidade do Estado para com a educação. A realização de parcerias com a iniciativa privada para que escolas públicas possam se manter é um outro modelo adotado nessa mesma linha. $O$ investimento em educação gera, pela lógica do sistema capitalista, a possibilidade de interferência direta das empresas no projeto pedagógico das instituições de ensino, ditando as regras segundo as quais serão formados nossos jovens. $\mathrm{O}$ drama dos desfavorecidos não seria apenas decorrente dos baixos salários, mas da educação focalizada, minimalista, empobrecida e, além disso, dissimulada.

As implicações desse quadro são reconhecidas e explicadas pelo governo central como conseqüências naturais do processo de democratização do ensino, contrapondo perda de qualidade ao aumento quantitativo de vagas. Essa impossibilidade "natural" de se equacionar esses fatores acaba por tirar a responsabilidade do poder público, pois parte do pressuposto que esse vem procurando fazer sua tarefa; por outro lado, culpabiliza a população que ocupa os bancos das escolas públicas pela sua inabilidade com o manejo do objeto educacional.

Como visto no capítulo I, no Brasil, assim como em outros países periféricos do mundo globalizado, há movimentos de resistência a esse modelo, no que tange à educação. A perspectiva sistematizada no Plano Nacional de Educação - Proposta da Sociedade Brasileira coloca a educação como direito fundamental, universal, inalienável e dever do Estado.

43 Pierre BOURDIEU, op. cit., 1998, p. 60. 
A educação entendida como um instrumento de formação ampla, de luta pelos direitos da cidadania e da emancipação social, preparando as pessoas e a sociedade para a responsabilidade de construir, coletivamente, um projeto de inclusão e de qualidade social para o país. [...] Ao Estado cabe a responsabilidade de assegurar e a cada cidadão 0 direito de exigir educação de qualidade social, igualitária e justa ${ }^{44}$.

\section{E continua:}

A qualidade social implica providenciar educação com padrões de excelência e adequação aos interesses da maioria da população, tendo como valores fundamentais: a solidariedade, a justiça, a honestidade, a autonomia, a liberdade e a cidadania, e como conseqüência a inclusão social, através da qual todos os brasileiros se tornem aptos ao questionamento, à problematização, à tomada de decisões, buscando as ações coletivas possíveis e necessárias ao encaminhamento dos problemas de cada um e da comunidade onde vivem e trabalham. A educação, nessa perspectiva, vai dirigir-se ao ser humano integral, englobando todas as dimensões de sua relação com o mundo ${ }^{45}$.

Eis as duas propostas para a educação. Uma, que adota princípios e critérios, tais como: ética, democracia e autonomia como condições para a qualidade. Essa primeira concepção adota um modelo que enfatiza, em especial, as funções diagnóstica e formativa da avaliação, considerando-a um processo abrangente, que se orienta por indicadores sociais. Outra, que adota os princípios e critérios tais como: eficiência, eficácia e produtividade priorizando a aferição pontual de desempenhos. Essa segunda concepção adota um modelo que privilegia indicadores técnicos e burocráticos de avaliação visando ao "ranquiamento" para o estabelecimento da competição justa.

Mergulhada nesse contexto, a escola, como instituição social, vivencia essa disputa de teses divergentes, como já mencionado.

Não há possibilidade de pensarmos o amanhã [...] sem que nos achemos em processo permanente de "emersão" do hoje, "molhados" do tempo em

44 Fórum Nacional em Defesa da Escola Pública, Plano Nacional de Educação - Proposta da Sociedade Brasileira, p. 9.

45 Idem, ibidem. 
que vivemos, tocados por seus desafios, instigados por seus problemas, inseguros ante a insensatez que anuncia desastres, tomados de justa raiva em face das injustiças profundas que expressam, em níveis que causam assombro, a capacidade humana de transgressão da ética. Ou também alentados por testemunhos de gratuita amorosidade à vida, que fortalecem, em nós, a necessária, mas às vezes combalida esperança. A própria ética do mercado, sob cujo império vivemos tão dramaticamente neste fim de século, é, em si, uma das afrontosas transgressões da ética universal do ser humano ${ }^{46}$.

O papel da escola pode ser caracterizado historicamente por três funções: a (re)apropriação dos conhecimentos acumulados pela Humanidade, por parte dos mais jovens; a preparação do jovem cidadão para o convívio em grupo ou sociedade; a qualificação para o trabalho ${ }^{47}$. As escolas seriam os locais instituídos para a transmissão de saberes construídos de acordo com os padrões culturais vigentes em determinada sociedade. Longe de representar, portanto, um instrumento de "salvação" social, ou unicamente de dominação, mas de natureza contraditória, a escola retoma seu papel constantemente, não de forma desenraizada dos condicionantes sócio-históricos, mas estabelecida na prática concreta de seus protagonistas $^{48}$.

É por meio das práticas escolares que se torna possível o acesso pleno à educação, vivência cidadã para além da sobrevivência mínima. Isso implica "conceber as instituições enquanto práticas sociais que, em sua particularidade, existem pela ação dos que cotidianamente a fazem e pelo reconhecimento desse fazer como uno, necessário e justificado" ${ }^{\prime 49}$.

Nessa leitura institucional, pode-se dizer que o efeito do conjunto de práticas concretas da instituição escola gera conhecimento que reorganiza a mesma. Essa, como instituição social, exprime de maneira determinada a estrutura e o modo de funcionamento da sociedade como um todo. Em seu interior, há a presença de

46 Paulo FREIRE, op. cit., 2000, p. 117.

47 Cf. Julio Groppa AQUINO, Do cotidiano escolar: ensaios sobre a ética e seus avessos, 2000, pp. 81 e 82 .

48 Esse conceito de protagonistas é referido na obra supracitada como as práticas entre os atores institucionais concretos - mais comumente os agentes e a clientela, e mais esporadicamente o mandante e o público.

49 Marilene GUIRARDO, Instituições e relações afetivas: o vínculo com o abandono, 1986, p. 14. 
opiniões, atitudes e projetos conflitantes que exprimem divisões e contradições sociais.

\begin{abstract}
"É uma ação social, uma prática social fundada no reconhecimento público de sua legitimidade e de suas atribuições, num princípio de diferenciação, que the confere autonomia perante outras instituições sociais, e estruturada por ordenamentos, regras, normas e valores de reconhecimento e legitimidade internos a ela" ${ }^{\prime 50}$.
\end{abstract}

Uma instituição difere de uma organização ${ }^{51}$. Enquanto a primeira estruturase por meio de ações articuladas às idéias de reconhecimento e legitimidade, a segunda é determinada por sua instrumentalidade; está referida ao conjunto de meios administrativos particulares para obtenção de um objetivo particular, tendo como referência as idéias de eficácia, previsão, controle e êxito. Não Ihe compete discutir ou questionar sua função e seu lugar na sociedade, pois se trata de um dado de fato. A eficácia da organização depende de seu diferencial de como gerir seu espaço e tempo para vencer a competição com seus supostos iguais, num esquema de auto-referência. A instituição tem a sociedade como seu princípio e sua referência normativa e valorativa, e busca responder às contradições que estão postas num dado momento histórico.

A escola configura-se como o lugar institucional autorizado de se fazer educação, pois é lá que ela é praticada comumente, referendada sua legitimidade e autoridade por aqueles que a praticam. O núcleo das práticas concretas escolares é a relação professor-aluno, uma vez que as instituições constituem-se como práticas sociais que se repetem e se legitimam enquanto se repetem.

O fortalecimento dos vínculos sociais, na escola, passa indubitavelmente pela potencialização das relações cotidianas entre seus atores concretos. Ou seja, trata-se de romper com a suposta natureza imutável do trabalho educativo e com os

50 Cf. Marilena CHAUÍ, A universidade pública sob nova perspectiva, 2003.

51 A distinção entre instituição social e organização social tem como fonte de inspiração a proposta de Marilena CHAUÍ em sua discussão sobre a universidade (ANPEd 2003), e atribuída à inspiração frankfurtiana, feita por Michel Freitag. 
modelos ideais estruturados, na retomada da escola como arena de embates que abriga diversos modos de vida na busca de consensos.

A partir do entendimento que a relação pedagógica tem como mediador e regulador o saber ${ }^{52}$, utilizar sua desconstrução e reconstrução e não uma narrativa sobre seus produtos ou a aplicação de certas receitas pedagógicas, no que diz respeito tanto aos alunos como agentes, constrói a escola como instituição social, como um lugar de encontro e diálogo, responsabilizando todos pela construção do conhecimento, e não apenas por sua transmissão e aquisição.

Forjar vínculos sociais consistentes é, de certa forma, um movimento de revolução possível diante das diretrizes impostas pelo sistema capitalista e uma forma de construir alternativas coletivas a um discurso que se pretende único e fatalista.

As crises características de cada momento histórico colocam o ser humano em questão. A educação, nesses tempos, pode ser entendida como possibilidade de desencadear um processo revolucionário e humanizador, oferecendo saídas para resolver os impasses no plano ético, dos valores, pois a escola e o conhecimento são reeducados pelo movimento da sociedade. Nesse sentido, a escola pode recuperar a humanidade que foi roubada dos sujeitos proporcionando "bons encontros".

A pedagogia dos excluídos, dos tempos de barbárie, não está na criação de novos métodos de empobrecimento educacional, mas em apreender o conjunto de processos que os oprimidos reinventam para continuar humanos. Essa pedagogia está pautada na escuta, no diálogo, no mergulho da trama social e cultural ${ }^{53}$.

52 Saber pode ser definido como tudo aquilo que a sociedade considera para sua preservação e consecução de seus fins e que, portanto, é historicamente determinado e hierarquizado em seu conteúdo e suas formas. O saber é objeto de transmissão cultural cuja natureza, extensão e condições de distribuição social determinam, em cada época histórica, as formas e condições de sua apropriação. Cf Maria Tereza ESTRELA, Relação pedagógica, disciplina e indisciplina, 1992.

53 Cf. Miguel ARROYO, "Educação em tempos de exclusão", pp. 270-279. 


\title{
IV. A INCLUSÃo COMO PARAdigma dA EdUCAÇÃo ESPECIAL
}

As proposições sobre educação inclusiva que constam nos documentos legais e oficiais analisados nos dois primeiros capítulos, por remeterem à idéia de educação para todos, podem ser apresentadas como derivadas do conceito dialético de inclusão/exclusão, ou ainda ser originárias da disputa pelo acesso ao sistema educacional comum de um grupo que tem sido historicamente objeto da educação especial $^{1}$.

A Declaração de Salamanca, entendida como fruto dos movimentos desse grupo, parte do pressuposto do direito de todas as pessoas à educação, afirmado na Declaração Universal de Direitos Humanos, e aponta para a renovação do empenho da comunidade mundial, já assegurado na Conferência Mundial sobre Educação para Todos, de garantir esse direito a todos, independentemente de suas diferenças particulares, as quais não podem ser alegadas como fator de discriminação e de exclusão.

\begin{abstract}
Aqueles com necessidades educacionais especiais devem ter acesso à escola regular, que deve acomodá-los dentro de uma pedagogia centrada na criança e ser capaz de satisfazer tais necessidades ${ }^{2}$.
\end{abstract}

Essa Declaração aponta como prioridade para os governos locais o aprimoramento dos sistemas da inclusão de todos, via implementação de políticas públicas educacionais. Para tal, propõe que estes busquem aperfeiçoar a leitura das diferentes características da população que está sendo atendida, de acordo com as especificidades de cada país, cidade ou município. A idéia norteadora é de que todas

1 A expressão "sistema regular de ensino" diz respeito à educação formal e regulamentada. O que não se encaixa no sistema regular de ensino pertence ao sistema informal, tendo-se como exemplos os cursos de línguas. As ofertas educativas para pessoas com deficiência, desde que formais, credenciadas, regulamentadas, pertencem ao sistema regular de ensino. O termo comum, em oposição ao especial, deve referir-se à proposta pedagógica diferenciada. A disputa pelo acesso ao ensino comum é respaldada pela noção do direito público de educação e pelo seu respectivo correlato, o dever do Estado em oferecer a todos os recursos que garantam a aprendizagem e a participação de todos os alunos.

2 Declaração de Salamanca - de princípios, política e prática para as necessidades educativas especiais. 
as crianças têm o direito à educação e que esta deve levar em conta seus interesses, habilidades e necessidades de aprendizagem. A Declaração, nesse sentido, não se dispõe a ser um receituário de ações que, quando aplicadas "corretamente", tendem a dar "bons" resultados, mas uma carta de consensos para a educação mundial na perspectiva da adoção de princípios de inclusão como base para o desenvolvimento de projetos educativos.

No Brasil, sua influência está bem caracterizada na legislação, como visto, embora, de fato, a consecução de um projeto de educação que inclua todos os alunos na rede de ensino não esteja garantida apenas por decretos, pois requer mudanças sociais na forma de encarar e lidar com a diferença.

Novamente, descarta-se uma idéia de uma fórmula a priori de inclusão, como se natural fosse, e reafirma-se o postulado de que todas as relações são historicamente construídas pelos sujeitos - inclusive conceitos como inclusão, justiça e solidariedade. Daí a inviabilidade do "treinamento" dos protagonistas sociais para a execução de um receituário preestabelecido, travestido em projetos de formação.

Esse trabalho de conceituação, discussão e posterior re-significação do conceito de educação inclusiva tem duas características básicas: partir da premissa consensuada socialmente acerca do direito indisponível de todos à educação e procurar implementar uma proposta de intervenção junto aos educadores no cotidiano escolar.

Além de reconhecer a educação como um direito fundamental de todos, as recomendações contidas nos documentos internacionais analisados anteriormente explicitam esse sentido das necessidades básicas de aprendizagem como dinâmicas e diversas, o que torna imperativa sua constante revisão - teórica e prática. Uma visão estática impossibilitaria que o diálogo entre essas postulações fosse realizado de forma efetiva, dificultando a adição de princípios desenvolvidos nesse ou naquele campo para o desenvolvimento do sistema educacional como um todo.

A questão da educação especial aparece, então, como uma das vertentes possíveis para esse debate. A prática de classificar por dicotomia a educação escolar em "comum" e "especial", bem como os educandos em "deficientes" e "não- 
deficientes", tem contribuído amplamente para a distorção e a desqualificação de diversas alternativas educacionais surgidas a partir de meados do século passado ${ }^{3}$.

O que parece estar em disputa são, por um lado, os discursos da socialização dessa clientela, de raízes assistencialistas, e o discurso da potência pedagógica dessa parcela da população, que pode ter benefícios educacionais reais ao ingressar na rede de ensino.

O redimensionamento do papel da escola como instituição legitimada socialmente e responsável pela educação de todos, cujos agentes teriam como funções a convocação de novos sujeitos do mundo e a transmissão desse cabedal acumulado pela Humanidade por meio de determinado campo conceitual, está colocado no cerne desse debate. Este breve resgate histórico da educação especial pretende subsidiar teoricamente quais seriam os princípios que têm embasado os movimentos da instituição escola para dar conta dessa tarefa. 0 pressuposto é o mesmo: os modelos teóricos que dão base à definição ou execução de políticas de atendimento às pessoas com deficiência são formatados no contexto da vida social e não pairam como verdades absolutas para sempre, pois estão imersos num mesmo sistema de valores, crenças e prioridades.

Dessa forma, a educação especial, desde os seus primeiros registros, tem se modificado, seja pelas pressões de grupos socialmente organizados, sobretudo os de pais de crianças e jovens com alguma deficiência, ou pelos profissionais que atuam com essa parcela da população, no que diz respeito a seus paradigmas ${ }^{4}$, locais onde é oferecida, objetivos etc.

O marco histórico inicial que será adotado neste trabalho é o advento dos hospitais psiquiátricos, em meados do século XVI, no bojo da revolução burguesa, cujo mote era a mudança do sistema de produção. Os Estados absolutistas começam a sucumbir às pressões liberais e, paulatinamente, passam a dar lugar aos Estados

3 Cf. Marcos José da Silveira MAZZOTA, "Dilemas e perspectivas da educação do portador de deficiência no novo milênio", 2001, pp. 29-36.

4 Um paradigma propõe problemas e soluções sobre determinado campo. É um conjunto de conceitos, valores, percepções e práticas compartilhadas por uma comunidade científica que apresenta uma determinada concepção da realidade, estruturada a partir de determinado tipo de pensamento construído em dado momento. Cf. Thomas KUHN, A estrutura das revoluções científicas, 1982, pp. 43-76. 
modernos; a sociedade começa a caracterizar-se por uma nova divisão social do trabalho, objetivada pela compra e venda de mão-de-obra para o trabalho - o chamado capitalismo mercantil. A noção de deficiência passa a ser, por um lado, assinalada como onerosa socialmente, dada a sua correlação com a nãoprodutividade e a impossibilidade de comercialização da força de trabalho dessas pessoas; por outro, com o avanço da Medicina, ela passa a ser vista de uma forma organicista. Os primeiros hospitais psiquiátricos eram pouco mais do que prisões, locais para confinar doentes, assim definidos por sua incapacidade de produção e conseqüentemente, marcados pela exclusão social.

No século XVII, a organização socioeconômica, já mais consubstanciada na lógica do capitalismo comercial, fortalecia o ideário de que as pessoas não são essencialmente iguais e que deveria haver respeito às diferenças, no sentido da legitimação social da desigualdade.

A relação da sociedade com a deficiência, a partir desse período, passou a se diversificar, ampliando o leque das possibilidades de ação: iniciativas de institucionalização para confinamento, tratamento médico ou para educação. Esta última passou também a ser oferecida pelo Estado, e não só pela Igreja, uma vez que passou a ter como objetivo maior o preparo de mão-de-obra para a produção.

O Paradigma da Institucionalização caracterizou-se, desde o início, pela retirada das pessoas com deficiência de suas comunidades de origem e pela manutenção delas em instituições residenciais segregadas ou escolas especiais, freqüentemente situadas em localidades distantes de suas famílias. Assim, pessoas com retardo mental ou outras deficiências, freqüentemente ficavam mantidas em isolamento do resto da sociedade, fosse a título de proteção, de tratamento, ou de processo educacional ${ }^{5}$.

A solução via instituições pode ser caracterizada pelo isolamento do "problema" da deficiência, e foi sendo alterada ao longo do tempo na busca de responder cada vez melhor aos anseios da sociedade. O tratamento, sempre que possível, era vinculado à educação sob a forma de treinamento, de modo a tornar

5 Maria Salete Fábio ARANHA, "Paradigmas da relação da sociedade com as pessoas com deficiência", 2001, p. 163. 
possível a inserção dessas pessoas no processo produtivo. A institucionalização e seu correlato, a segregação, permaneceram durante muitas décadas como recurso social possível e adequado, encampando uma grande diversidade de atitudes: desde a institucionalização em conventos e hospícios até o ensino especial.

Já no século XX, especialmente após as duas Grandes Guerras, os Estados Nacionais começam a reconhecer seu dever para com a educação de todos, entendida agora como direito. O trato da deficiência, no que se referia a suas necessidades de educação e de treinamento, estava contido nessa premissa. Assim, pode-se dizer que houve um desenvolvimento das ações de responsabilidade pública para dar conta dessas atividades, embora a tendência fosse manter o atendimento fora do setor público, sob iniciativa e sustentação do setor privado. O movimento da escolarização para todos, com o objetivo de formar cidadãos produtivos e a mão-deobra necessária para a produção, requeria que todos tivessem "treinamento" adequado; porém, no caso dos deficientes, a opção por ambientes segregados ainda era hegemônica.

Apenas na década de 1960 as críticas com referência à própria inadequação e ineficiência das instituições no favorecimento da recuperação das pessoas para a vida em sociedade começam a ser realizadas pelos próprios profissionais que atendem nesses locais. Nesta época, tem-se a formação de um tripé interessante: o Estado, "preocupado" com a diminuição dos custos de manutenção com uma população segregada, que na sua maioria era improdutiva; a sociedade, em busca de um novo consenso, com movimentos de reflexão coletiva sobre direitos humanos ${ }^{6}$; e as instituições, sofrendo críticas e manifestações contrárias à sua existência por parte da academia científica e das diferentes categorias profissionais ligadas a ela.

A convergência desses fatores, embora diversos quanto à sua natureza e motivação, vieram a dar corpo para a reformulação de idéias e a busca de novas práticas no trato da deficiência. À luz das concepções de "desvio" e de "normalidade", foi-se configurando, gradativamente, um novo paradigma de relação

6 A Declaração Universal dos Direitos Humanos, datada de 10 de dezembro de 1948, expressa esse consenso social. 
entre a sociedade e a parcela da população representada pelas pessoas com deficiência: o paradigma de serviços, da integração ou ainda da normalização.

Seu mote era normalizar comportamentos para integrar as pessoas na sociedade, possibilitando o ingresso no mercado de trabalho e a conseqüente diminuição do custo dos doentes para o Estado. A concepção de deficiência, correlata à de doença, era agora, com o avanço da medicina, da psicologia e outras ciências, passível de mensuração e classificação, o que possibilitava uma divisão mais fidedigna entre treináveis e educáveis, otimizando o investimento tanto do Estado como da sociedade, que se volta apenas para aqueles que poderiam ser normalizados, ou seja, para os que poderiam adquirir as condições e os padrões da vida cotidiana mais próximos do normal.

O princípio da normalização, portanto, deu o apoio filosófico ao movimento da desinstitucionalização, favorecendo tanto o afastamento da pessoa das instituições, como a provisão de programas comunitários planejados para oferecer serviços que se mostrassem necessários para atender a suas necessidades ${ }^{7}$.

A visão da deficiência como déficit passível de tratamento/treinamento para sua eliminação ou minimização continuava a ser a perspectiva teórico-científica que subsidiava a atuação dessas instituições. A idéia passa de um tratamento homogeneizado para a especialização dos serviços. É importante ressaltar que uma visão não foi substituída totalmente pela outra, mas que os dois paradigmas passaram a "conviver" e a subsidiar as ações sociais com relação à deficiência. "As instituições foram se especializando para atender por tipo de deficiência. Assim, a segregação institucional continuou sendo praticada" ${ }^{\prime 8}$.

Especificamente na área da educação, além da normalização, o mainstreaming foi uma outra forma de avançar na aquisição de conhecimentos e na

7 Maria Salete Fábio ARANHA, op. cit. , 2001, p. 167.

8 Romeu Kazumi SASSAKI, Inclusão: construindo uma sociedade para todos, 1999, p. 31.

9 Prática associada ao movimento de desinstitucionalização que consistia em colocar alunos com deficiência em classes comuns para acompanhar as aulas. Não havia uma preocupação com o avanço pedagógico desses estudantes, dado que o objetivo principal era sua presença na escola comum, embora, não raramente, se tratasse de uma simples colocação física. Cf. Romeu Kazumi SASSAKI, op. cit. , 1999, p. 33. 
realização de experiências de integração. Como essa perspectiva localizava na pessoa o alvo da mudança, os investimentos eram voltados para o desenvolvimento de serviços e recursos que pudessem torná-las próximas do padrão social. As escolas e as classes especiais, mais claramente voltadas para o ensino do aluno, visando a sua ida ou ao seu retorno para as salas de aula denominadas normais, são outros exemplos de como a integração poderia ser viabilizada. A educação desses grupos pode ser caracterizada por um processo de ensino-aprendizagem de natureza patológica e parte integrante do processo de normalização para integração social. 0 objetivo era dar condições mínimas de inserção no mercado, visando à sobrevivência autônoma, para diminuir o custo para o Estado. A consideração do fracasso escolar iminente atribuído a fatores médicos e, portanto, extra-escolares e individuais, impulsionou a criação de equipes de diferentes profissionais especializados em educação para oferecer treinamento mais focado nas necessidades de cada doença previamente diagnosticada.

O modelo de atenção adotado passou a se constituir de três etapas: a primeira, de avaliação, onde uma equipe de profissionais identifica o que, em sua opinião, necessita ser modificado no sujeito ou em sua vida, de forma a torná-lo o mais "normal" possível. A fase seguinte, conseqüência desta e a ela conseqüente, chamada de intervenção (ensino, treinamento, capacitação etc.), onde profissionais passam a oferecer atendimento formal e sistematizado ao sujeito em questão, norteados pelos resultados e decisões tomados na fase anterior. [...] A última fase, constituída do encaminhamento ou reencaminhamento desta para a vida na comunidade $^{10}$.

A prontidão dos alunos em se adaptarem à escola e a incorporação nas escolas regulares das práticas das escolas especiais eram fatores fundamentais para o sucesso da integração de cada pessoa.

A integração escolar, cuja metáfora é o sistema de cascata, é uma forma condicional de inserção em que vai depender do aluno, ou seja, do nível de capacidade de sua adaptação às opções do sistema escolar, a sua integração, seja em sala regular, uma classe especial, ou mesmo em

10 Maria Salete Fábio ARANHA, op. cit. , 2001, p. 168. 
instituições especializadas. Trata-se de uma alternativa em que tudo se mantém, nada se questiona do esquema em vigor ${ }^{11}$.

Na década de 1980, o movimento da luta pelos direitos das pessoas portadoras de deficiência cresce e, no início de 1990, aponta como fundamental a equiparação de oportunidades para que todas as pessoas possam ter acesso a todos os serviços, bens e ambientes, em busca da realização de seus sonhos e objetivos, baseado em conceitos como autonomia, independência e empowerment ${ }^{22}$.

O que se pleiteava, em termos gerais, era a garantia, para além dos serviços especializados, de participação nas atividades sociais e da convivência não segregada. A deficiência passa a ser entendida como uma condição iniciada na consideração da diferença e construída socialmente. Em virtude de tal debate, a idéia da normalização começou a perder força, dando lugar ao conceito de respeito às diferenças. O cerne não era mais a legitimação das desigualdades, como nos séculos XVI e XVII, mas a consolidação da perspectiva da pessoa com deficiência ser um cidadão, detentor dos mesmos direitos de determinação e usufruto das oportunidades disponíveis na sociedade, independentemente do tipo de deficiência e de seu grau de comprometimento. A própria busca de uma nomenclatura que ao mesmo tempo minimizasse a rotulação, que justifica e perpetua a segregação, e que descrevesse e enfatizasse os desafios do sistema pôde ser observada ao longo do texto, com a variação das designações para essas pessoas: doente, deficiente, pessoa portadora de deficiência ou pessoa com deficiência. Esse movimento da linguagem, que ajuda a criar e a sustentar estereótipos e preconceitos baseados na idéia das características comuns entre pessoas vinculadas a um determinado rótulo, ilustra o movimento de se priorizar o atendimento específico para cada "doença",

11 Maria Teresa Eglér MANTOAN, A integração das pessoas com deficiência: contribuições para uma reflexão sobre o tema, 1997, p. 8.

12 Embora esses termos já tenham sido utilizados nos modelos anteriores, uma nova significação foi atribuída a eles no sentido de ter como foco as pessoas e não as deficiências. Assim, autonomia passa ser entendida como a condição de domínio no ambiente físico e social, preservando ao máximo a privacidade e a dignidade da pessoa que a exerce; independência como a faculdade de decidir sem depender de outras pessoas; e, finalmente, empowerment como o processo pelo qual uma pessoa usa seu poder pessoal inerente à sua condição para fazer escolhas e tomar decisões, assumindo o controle de sua vida. Cf. Romeu Kazumi SASSAKI, op. cit. , 1999, pp. 32-39. 
sendo substituído por uma visão que destaca a pessoa e a busca de serviços que não estão disponíveis para sua inclusão social, segundo a qual a diversidade e a diferença são entendidas como características humanas e o esforço social deve ser no sentido de mudar o que está disponível para atender a todos.

\begin{abstract}
Essas duas noções definem processos mentais pelos quais se operam a descrição e o julgamento de pessoas ou grupos, que são caracterizados por pertencer a uma determinada categoria social ou pelo fato de apresentar um ou mais atributos próprios a esta categoria. O preconceito é um julgamento positivo ou negativo, formulado sem exame prévio a propósito de uma pessoa ou de uma coisa a que assim, compreende vieses e esferas específicas. Disposto na classe das atitudes, o preconceito comporta uma dimensão cognitiva, especificada em seus conteúdos e sua forma estereotipia, uma dimensão afetiva ligada às emoções e valores engajados na interação com o alvo, uma dimensão conativa, a descrição positiva ou negativa. [...] Eles são considerados como resultantes de processos de simplificação próprios ao pensamento do senso comum ${ }^{13}$.
\end{abstract}

São duas as afirmações principais: que as pessoas com deficiência necessitam de serviços nas áreas física, psicológica, educacional, social e profissional, oferecidos no contexto de suas comunidades, e que a sociedade deve se reorganizar de forma a garantir o acesso de todos os cidadãos a tudo o que a constitui e caracteriza, independentemente de quão próximos estejam do padrão vigente de normalidade. Foi fundamentado nessas idéias que surgiu o terceiro paradigma, denominado paradigma de suporte ou da inclusão.

O Paradigma do Suporte constitui-se da disponibilização ao cidadão com deficiência, de todo e qualquer apoio que se mostre necessário para otimização de seu potencial para uma vida de qualidade e que permita sua real inclusão em todas as áreas de sua existência: vida doméstica, escola, familiar, social mais ampla, profissional e econômica. Os suportes são delineados e planejados para atender os desejos e necessidades individuais [...] e refere-se a toda e qualquer tipo de ajuda que permita a pessoa com deficiência maior nível de autonomia e independência na administração e gerenciamento de sua própria vida. Assim ele não pode ser algo padronizado e preestabelecido ${ }^{14}$.

13 Denise JODELET, "Os processos psicossociais da exclusão", 2001, p. 59.

14 Cf.Maria Salete Fábio ARANHA, "A integração social do deficiente: análise conceitual e metodológica", Temas em Psicologia, 1995, p. 35. 
A inclusão parte do mesmo pressuposto da integração, que é o direito de a pessoa com deficiência ter igualdade de acesso ao espaço comum da vida em sociedade. Difere, entretanto, no sentido de que a idéia da integração pressupõe mudanças do indivíduo, na direção de sua normalização. As alterações nas instâncias sociais podem ou não ocorrer como complementação ou decorrência ao processo de intervenção no sujeito. Já a idéia da inclusão prevê intervenções tanto no processo de desenvolvimento do sujeito como no processo de rearranjos sociais que se mostrem necessários para que a pessoa com deficiência tenha condições de acesso ao espaço comum da vida na sociedade.

A inclusão institui a inserção de uma forma mais radical, completa e sistemática, uma vez que o objetivo é incluir um aluno ou um grupo de alunos que não foram anteriormente excluídos. A meta da inclusão é, desde o início, não deixar ninguém fora do sistema escolar, que terá de se adaptar às particularidades de todos os alunos para concretizar a sua metáfora _ o caleidoscópio. Este instrumento precisa de todos os diferentes pedaços que o compõem para configurar os desenhos que se formam indefinidamente com os arranjos de seus elementos a cada giro do objeto pelo seu manipulador ${ }^{15}$.

A análise histórica da educação especial e de seus paradigmas contextualizados na organização social permite, a partir das exigências produtivas inerentes ao capitalismo, vislumbrar que as pessoas que podem comercializar sua força de trabalho são consideradas apropriadas e aqueles que não se adequam passam a ser vistos como desviantes, inaptos e não adaptados. Algumas características individuais, definidas como deficiências ou não, quando adquirem um sentido de desvalorização naturalizado pelo modelo produtivista levam à segregação, à exclusão social. Esses condicionantes limitam ou impedem a participação de grupos estigmatizados na sociedade, comprometendo assim, progressivamente, sua apreensão do real e seu conseqüente desenvolvimento, e inviabilizando o trato das diferenças como elementos constitutivos da própria natureza humana. Iniciativas para a inclusão de todos, além de ação política no sentido de garantir o cumprimento da lei e de esforços de ampliar a participação efetiva dos grupos historicamente 
estigmatizados, mostram-se necessárias e importantes para que a prática social se torne consistente com seu discurso.

Pode-se afirmar que as pessoas com deficiência estão, de qualquer forma, incluídas no sistema como consumidores de bens e de serviços especializados. Esse tipo de inserção por intermédio do consumo dirigido estabelece relações diferenciadas para categorias hierarquizadas de cidadãos.

A Declaração de Salamanca pode, então, ser mencionada como o documento que representa a concretização de um consenso mundial em torno do paradigma da inclusão na educação, pois propõe uma mudança social para que seja possível lidar com toda a diversidade humana, e não apenas uma adaptação do indivíduo ao padrão considerado de normalidade. Caminha no sentido oposto ao da classificação e patologização do indivíduo, privilegiando uma leitura da deficiência como diferença, e dessa como inerente à condição humana.

O princípio fundamental da escola inclusiva consiste em que todas as pessoas devem aprender juntas, onde quer que isto seja possível, não importam quais as dificuldades ou diferenças elas possam ter. Escolas inclusivas precisam reconhecer e responder às necessidades diversificadas de seus alunos, acomodando os diferentes estilos e ritmos de aprendizagem e assegurando educação de qualidade para todos mediante currículos apropriados, mudanças organizacionais, estratégias de ensino, uso de recursos e parcerias com suas comunidades ${ }^{16}$.

Nessas condições, a educação especial é colocada em xeque, uma vez que uma visão ampliada do direito contempla a todos, inclusive os que têm sido historicamente objeto da mesma.

Toda e qualquer investida no sentido de se ministrar um ensino especializado no aluno depende de se ultrapassarem as condições atuais de estruturação do ensino escolar para deficientes. Em outras palavras depende da fusão do ensino regular com o especial. [...] Fundir significa incorporar elementos distintos para se criar uma nova estrutura, na qual desaparecem os elementos iniciais, tal qual eles são originariamente ${ }^{17}$.

16 Declaração de Salamanca - de princípios, política e prática para as necessidades educativas especiais.

17 Maria Teresa Eglér MANTOAN, op. cit. , 1997, p. 7. 
O duplo papel que a educação especial tem cumprido de, por um lado, auxiliar no processo de democratização do ensino ao atender uma parcela da população que não teria acesso à escola comum e, por outro, legitimar a segregação do diferente, não necessariamente significou o acesso dessa parcela da população a uma educação especializada. Ao não incorporar a maior parcela das crianças com deficiência e encobrir a inexistência de uma política de acesso à escola para esse grupo, ela tem contribuído para a disseminação do discurso da incapacidade e da improdutividade ${ }^{18}$.

Além disso, a partir de 1970, no Brasil, com a difusão dos métodos científicos de diagnóstico diferencial na educação, foram incorporadas como alvos da educação especial pessoas com "distúrbios e deficiências", que trazem imbricadas nessa avaliação as condições socioeconômicas, numa relação entre determinado e determinante que mistura várias concepções teóricas da produção do fracasso escolar, que ora culpabilizam a clientela - aluno e sua família - pelo mau desempenho acadêmico, ora a instituição escolar e seus protagonistas pela falta de preparo em lidar com grupos estigmatizados que entram na escola nessa época, reforçando o caráter patológico da educação para essa população. "Diagnósticos da precariedade da escola pública [...] continuam a conviver com a afirmação de que crianças pobres são portadoras de dificuldades escolares que lhes são inerentes ${ }^{\prime 19}$.

A partir de 1988, com a promulgação da Constituição Federal, a relação da pessoa com deficiência com a educação escolar parece estar estabelecida consoante a uma postura mais dinâmica. O princípio é o de que todas as escolas têm necessidades comuns e especificidades. Assim, os alunos, independentemente de deficiências físicas, mentais ou sensoriais, apresentarão necessidades educacionais especiais e comuns em relação ao que se espera deles e ao que é oferecido na escola; e somente em situações concretas em que se encontram os alunos nas escolas é que se pode chegar a especificá-las. Classificações apriorísticas baseadas

18 Cf. José Geraldo Silveira BUENO, "A integração social das crianças deficientes: a função da educação especial", 1997, pp. 57-61.

19 Maria Helena de Souza PATTO, A produção do fracasso escolar: histórias de submissão e rebeldia, 1990, p. 151. 
em preconceitos podem conduzir a ações estereotipadas que não contribuem para o cumprimento da função social da escola. Para tal, são importantes tanto a análise de cada situação de ensino-aprendizagem concreta construída nas escolas em sua singularidade, quanto uma leitura fidedigna da realidade social em que se encontra, num diálogo constante.

Os objetivos da educação estabelecidos pela Lei de Diretrizes e Bases para a Educação Nacional (Lei 9394/96) asseguram uma formação comum, não comportando qualquer tipo de exclusão de crianças, jovens ou adultos, sob pretexto algum. A educação, nessa perspectiva, passa a privilegiar o acesso ao conhecimento e à escola como o local privilegiado para executar essa tarefa. Assim, o sistema escolar deve contar com serviços educacionais escolares especializados para atender a todos alunos que apresentem necessidades educacionais especiais.

Como já foi dito, a procura por uma nominação que traduza o momento histórico com maior fidedignidade tem, hoje, no conceito de "necessidades educacionais especiais", aquele que atende de forma mais clara aos atuais objetivos da educação. A educação escolar tem como finalidade promover, de forma intencional, o desenvolvimento de capacidades e a apropriação de conteúdos da cultura que são fundamentais para que as pessoas depois se tornem membros ativos dessa mesma cultura, ou seja, cidadãos. As necessidades educacionais especiais não se definem pela origem do problema, mas pelo tipo de resposta educativa e pelo tipo de recursos que se devem prover. Não é sinônimo de deficiência, e, portanto, não pode substituí-lo como conceito. A deficiência, por sua vez, segundo esse entendimento, não define o que a pessoa é em sua totalidade, não explica totalmente o nível de desenvolvimento de aprendizado, é, sim, mais uma condição da própria.

A idéia de inclusão tem como base que todos tenham o direito de serem educados juntos na escola da sua comunidade, e que essa se modifique com relação à sua estrutura, funcionamento e tipos de respostas educativas, de modo que se tenha lugar para todas as diferenças individuais, inclusive aquelas associadas a alguma deficiência. A educação inclusiva implica, assim, a transformação tanto da educação comum como da educação especial, para que essa contribua de maneira 
significativa ao desenvolvimento de escolas de qualidade para todos, como apoio imprescindível, dado o conhecimento acumulado na área. Há uma grande parcela de pessoas com deficiência que, em situação escolar, não necessitam de nenhum tipo de atendimento especializado, podendo se beneficiar dos serviços escolares comuns. A escola encontra-se, assim, perante este duplo desafio: conseguir que todos adquiram as bases da cultura que lhes permitam inserir-se com maior igualdade de condições no mundo e, ao mesmo tempo, conseguir conciliar as diferenças individuais, culturais e sociais.

Pode-se notar uma enunciação desses preceitos na legislação brasileira atual, mas a simples mudança de termos, quer nos planos educacionais, quer nos documentos oficiais, não é suficiente, e, por vezes, pode gerar negligência em relação a ações governamentais, delegando aos especialistas o estabelecimento de etapas modulares para a instalação de "escolas inclusivas" como metas governamentais. Quando mais, pode ainda significar a mera adaptação terminológica, fazendo com que a discussão se reverta numa questão de modismo semântico que envolve a manipulação intencional de informações e dados, e não a construção cotidiana da escola objetivada na possibilidade de participação de todos em todas suas atividades.

O Brasil mantém, no panorama de suas relações com as parcelas da população representadas pelos grupos estigmatizados, entre elas as pessoas com deficiência, resquícios de todos os paradigmas mencionados: segregação, integração e inclusão. Essa perspectiva teria como norte romper com a dicotomização da educação escolar entre comum e especial como sinônimo de à margem. Nesse sentido, um projeto unificado configurado em cada escola que possa refletir cada realidade específica, ou seja, que leve em conta fatores internos e externos que influenciam na organização e no funcionamento da mesma, e que favoreça o atendimento das reais necessidades dos alunos e não de categorias e tipos idealizados, sem deixar de lado os conhecimentos socialmente construídos e suas atualizações, pode proporcionar a união dos fazeres dos professores do ensino comum e os do especial em torno desta tarefa. "Através do planejamento com e 
'para' toda a escola, a exploração compartilhada [...] pode esclarecer as idéias que norteiam e organizam a vida cotidiana na instituição escolar ${ }^{\prime \prime 20}$.

A inclusão como base da vida social tem como foco a importância de cada cidadão estar junto com os demais em todos os contextos, o que implica essencialmente a vivência de sentimentos e atitudes de respeito ao outro. Sua existência no aparato legal dá "brechas" para que haja um empenho dos protagonistas sociais em atuar por meio da reflexão sistemática e cotidiana, fomentada pelo compromisso público voltado para a resolução dos problemas e conflitos, o que se distingue totalmente da imposição de uma perspectiva inclusiva como reforma escolar. Há um discurso corrente tanto no senso comum como na voz dos mais diversos especialistas, que o desempenho geral das escolas tem se caracterizado como abaixo das expectativas, mesmo antes da entrada legalmente sustentada de crianças com deficiências, o que estimula várias tentativas de responder a essa demanda com um "modelo de escola melhor". Assim, os administradores públicos, no sentido de atender os discursos dos diversos setores (especialistas, da sociedade e das leis), têm estabelecido diretrizes administrativas, que, "utilizando" o mote da inclusão, propõem uma mudança estrutural a ser efetivada mediante a aplicação de uma série de passos preestabelecidos. Essa "imposição" feita de fora para dentro e de cima para baixo aumenta a possibilidade de a inclusão unir-se à longa lista de reformas institucionais decepcionantes. Os protagonistas, sem terem participado das discussões de planejamento dessas políticas, e no afã de aplicar a prática recomendada, podem simplesmente tornar a rotular suas atividades atuais como inclusivas, repetindo palavras mais "politicamente corretas" para dizer de uma nova forma do que eles já faziam há muito, e sem reflexão coletiva para repensar as ações.

Porém, como a educação acontece no contato com os outros, o compromisso social precisa ser renovado diariamente, no sentido de a coletividade enfrentar as dificuldades e renegociar limites e estruturas. Não se trata, portanto, de uma corrida adaptativa baseada na competição, pois não há um "modelo ideal" que

20 John O'BRIEN e Connie Lyle O'BRIEN, "A inclusão como uma força para a renovação da escola", 1999, p. 55. 
sirva para todas as escolas, mas sim da potencialização de ações dos protagonistas para que todos atuem como participantes do funcionamento da escola e como colaboradores no seu planejamento. Os princípios da inclusão aplicam-se não somente aos alunos com deficiência ou sob risco, mas a todos os alunos e a todos os professores. Boas escolas são escolas boas para todos os que nela se relacionam e buscam a compreensão das questões fundamentalmente humanas de seu cotidiano, de modo a organizar ações sustentadas.

A título de encerramento, serão pontuados dez elementos críticos para a criação de escolas inclusivas ${ }^{21}$, que foram, na medida do possível, adaptados à realidade brasileira. "Os elementos a seguir são características que, quando presentes em uma escola e em um sistema escolar, contribuem para o sucesso de todos os alunos" ${ }^{\prime \prime 2}$.

$\checkmark \quad$ Desenvolver uma filosofia comum e um plano estratégico, sustentado nos princípios de uma educação de qualidade para todos, o que deve incluir todas as pessoas que estão diretamente envolvidas no cotidiano escolar alunos, pais, educadores, diretores, pessoal de apoio e membros da comunidade - retirando a exclusividade dos especialistas na tomada de decisões a respeito do planejamento educacional, e estabelecendo um diálogo com esses.

$\checkmark$ Proporcionar uma liderança forte que reconheça suas responsabilidades na definição dos objetivos da escola e na garantia da tomada de decisões para o enfrentamento de desafios e o apoio aos processos compatíveis com a filosofia da escola. A direção deve proporcionar meios para que os professores possam aprender novas práticas educacionais e desenvolver com eles uma concepção de disciplina que vigore por toda a escola.

$\checkmark$ Promover culturas no âmbito da escola e da turma que acolham, apreciem e acomodem a diversidade. As escolas espelham valores e práticas

21 Cf. C. Beth SCHAFFNER e Barbara E. BUSWELL, "Dez elementos críticos para a criação de comunidades de ensino inclusivo e eficaz", 1999, pp. 69-87.

22 Idem., p. 69. 
culturais que existem fora de seus muros e fomentam o desenvolvimento de atitudes, interesses e habilidades nos membros mais jovens da sociedade. Para que as pessoas possam ser valorizadas como colaboradores na construção do bem comum, em que todos compartilhem direitos básicos, é necessário cuidar de tudo o que é ensinado, assim como o modo pelo é ensinado, deixando clara, pública e intencional a filosofia escolar. É na escola que alunos e professores passam uma grande quantidade de horas e é lá que muitas de suas conexões sociais são feitas, portanto, deve ser realizado um esforço conjunto para o desenvolvimento de "bons encontros". Algumas estratégias para atingir esse objetivo são: tarefas cooperativas em detrimento das competitivas; rotinas para que todos recebam o apoio necessário para participar de todas as atividades de forma plena, inclusive na tomada de decisões.

$\checkmark$ Desenvolver redes de apoio $^{23}$ que podem incluir vários tipos de equipes e outros sistemas que ajudem a garantir o cumprimento da missão da escola e de efetivamente satisfazer às necessidades de todos os alunos, como por exemplo, os GAAE, os PÓLOS, os NAEs, o sistema de saúde etc.

$\checkmark \quad$ Usar processos deliberativos para garantir a diminuição da discrepância entre o planejamento no papel e sua real implementação. Um problema adicional é que as horas de trabalho coletivo, em geral, tornam-se sessões superficiais para o preenchimento de formulários, em vez de sessões dinâmicas de resolução de problemas e criação de estratégias de atendimento. Para piorar, em muitos casos, as horas de trabalho coletivo são as únicas possibilidades de encontro dos professores para organizar o planejamento escolar, e tendem a destacar os problemas urgentes dos alunos, centrados em suas dificuldades e déficits, e não em estratégias de ação. A disseminação dos insucessos dos alunos faz com que eles se tornem bodes expiatórios e sejam considerados culpados por suas exclusões, além

23 Cf. Idem, p. 74. Diferente de redes de apoio "uma equipe de apoio é um grupo de pessoas que se reúne para debater, resolver, trocar idéias, métodos, técnicas e atividades para ajudarem professores e/ou os alunos a conseguirem apoio de que necessitam para serem bem sucedidos em seus papéis". 
de contribuir para a legitimação e perpetuação dessa "avaliação". A possibilidade de planejamento deliberado e contínuo, com reuniões regulares, para modificar o plano de apoio quando necessário, a focalização nas potencialidades dos alunos e a inclusão de outros membros como participantes das reuniões auxiliam na distribuição mais eqüitativa de responsabilidades, para que não haja a preocupação de se explicar 0 problema nem de justificá-lo por meio da culpa deste ou daquele. A garantia de reuniões eficientes passa por designar papéis; estabelecer uma agenda com limites de tempo para os itens a serem discutidos; iniciar com o reconhecimento de sucessos; concluir com um plano de ação que deve conter quem vai fazer o quê e quando; registrar os procedimentos em quadros na parede; providenciar a transcrição dos procedimentos para todos após cada reunião.

$\checkmark \quad$ Desenvolver uma assistência técnica organizada e contínua para os momentos em que os educadores são solicitados a implementar práticas educacionais que se afastam significativamente de suas práticas tradicionais. Assim, a escola deve estabelecer um plano para oferecer assistência técnica para os profissionais envolvidos obterem informação e apoio. Este plano deve incluir: funcionários especializados dentro e fora da escola para atuarem como consultores e facilitadores; uma biblioteca atualizada; recursos de vídeo e áudio; um plano condizente, abrangente e contínuo de formação em serviço; reuniões coletivas para tratamento de questões comuns e para o desenvolvimento criativo de novas estratégias de ajuda mútua; visitas a outras escolas.

$\checkmark \quad$ Manter a flexibilidade para apoiar os alunos com dificuldades. Nesse sentido, os educadores devem desenvolver a espontaneidade, a flexibilidade e a coragem de assumir riscos numa orientação do que pode ser feito, e buscando oportunidade nas situações para viabilizar uma educação de qualidade para todos. Quando os problemas ocorrem, a melhor estratégia é voltar para a etapa de planejamento e determinar uma maneira diferente de proceder, em vez de encaminhar alunos. 
$\checkmark \quad$ Examinar e adotar abordagens de ensino efetivas para educar alunos em diferentes níveis de desempenho. Os professores necessitam fazer uma reavaliação das práticas de ensino com as quais se sintam mais à vontade, $\mathrm{e}$ não se sentirem impelidos a usar uma abordagem "tamanho único". Devem promover uma aprendizagem mais ativa do que passiva, a cooperação em vez da competição, e habilidades de pensamento crítico em vez de aprendizagem mecânica. No caso da educação especial e da educação comum, a existência de dois sistemas de ensino paralelos reforçou o mito que alunos com deficiência aprendem de forma tão diferente que é necessário um método de ensino distinto dos usados com os estudantes comuns. A percepção de muitos professores é a de que a tarefa de educar grupos estigmatizados requer conhecimento, experiência, equipamento, treinamento e, por vezes, um local diferenciado, numa orientação baseada em linhas categoriais. Num ambiente escolar dinâmico, os educadores podem incorporar as abordagens que eles julgam bem-sucedidas em seu repertório, sem com isto se sentirem ameaçados.

$\checkmark$ Comemorar o sucesso e aprender com os desafios para aumentar a possibilidade de que um modelo bem-sucedido não desapareça quando quem o instituiu não está mais envolvido, e que os demais voltem a recorrer a antigas práticas. Essas inovações bem-sucedidas só têm efeito de mudança quando esforços deliberados são realizados para incorporá-las na política e na prática cotidiana.

$\checkmark \quad$ Estar a par do processo de mudança, mas não admitir que ele 0 paralise, pois as mudanças de atitude não têm de preceder as mudanças de comportamento. Por isso, esperar que as atitudes das pessoas sobre determinada inovação mudem antes que a mudança seja implementada não promove tal transformação. A preparação de todos os envolvidos ou a implementação da educação inclusiva em passos predeterminados ignora que esta é uma questão social e que deve ser apoiada pela escola para que não sucumba, por meio de um planejamento estratégico envolvendo todas as pessoas responsáveis. 
Destarte, no campo da educação, a inclusão pode envolver um processo de reestruturação das escolas como um todo, com o objetivo de assegurar que todos possam ter acesso a todas as oportunidades educacionais e sociais oferecidas pela mesma. Nessas escolas que têm como perspectiva a inclusão, os talentos de cada um são reconhecidos, estimulados e potencializados. Cada pessoa é um membro importante e valioso com responsabilidades e com um papel de apoio aos demais, o que ajuda a fomentar o respeito mútuo e um sentimento de pertencimento e de valor entre todos. Pode-se dizer que a inclusão/exclusão se reproduz na escola, pois são as experiências cotidianas que definem a qualidade da participação das experiências de aprendizagem oferecidas, que podem ou não gerar "bons encontros". Da mesma maneira, são importantes as interações e as relações sociais entre os protagonistas e destes com a clientela.

Embora haja uma orientação legalista assegurada pelas diretrizes da educação, que aponta como meta a operacionalização da "inclusão escolar" de todos os alunos, independentemente de classe, etnia, gênero, sexo ou outras características, numa clara demonstração do respeito às diferenças, em âmbito nacional esse empenho garante muito mais o acesso de grupos estigmatizados, dado que a inclusão é um processo que nunca termina, uma vez que se refere ao desenvolvimento organizacional e pedagógico contínuo do sistema de ensino objetivado em seu cotidiano.

Na perspectiva de uma educação estabelecida na diversidade, a formação dos professores deveria acompanhar esse movimento. Dessa forma, partindo do que se tem em sala de aula e dos conhecimentos prévios dos protagonistas, frutos de formação inicial e/ou experiências práticas, a formação pedagógica deveria ser realizada no interior das escolas continuamente, à medida que as questões possam ser formuladas de modo coletivo como forma de encontrar meios de alcançar níveis que não eram contemplados. Trata-se de um tipo de formação que busca aprimorar o que o professor já aprendeu em sua formação inicial, dando oportunidade de reexaminar as teorias e práticas educativas, e encontrando alternativas para a formulação de um planejamento coletivo. "No centro do projeto estão os participantes, os que vão assumi-lo, responsabilizar-se por ele no dia-a-dia. 
Conteúdos que eles vão escolhendo, por acreditarem que seria importante para a sua prática, para construir o seu saber, Ihes possibilitando identificar o que e de que forma estão fazendo" ${ }^{\prime 24}$.

Nesse sentido, o resgate dos alunos como participantes efetivos do processo de escolarização só é possível com o fortalecimento do lugar institucional dos professores, na condição de protagonistas sociais responsáveis pelo cumprimento da função social da escola. A articulação do conhecimento numa prática mais coletiva e solidária, adequando os conteúdos e construindo o saber com as experiências de todos, possibilita o enfrentamento dos problemas da escola e, conseqüentemente, a superação dos mesmos, visando a atingir os objetivos propostos. A inclusão escolar passa, portanto, pela inclusão do professor no processo educativo, entendido como um trabalho contínuo que envolve planejamento, implementação, avaliação, e que possibilita uma atuação mais autônoma mediante o projeto político-pedagógico. "A questão fundamental na prática política não é o puro fazer coisas, mas em favor de que e de quem fazer coisas, que implica, em certo sentido, contra quem fazer coisas $^{\prime 25}$.

O trabalho que se coloca, uma vez que não há modelos prontos nem receitas em manuais, é aproximar a lei que se tem com a prática que se quer na convivência cotidiana com a diversidade que caracteriza a Humanidade e que a enriquece, dando sentido e significado para a educação num espaço comum.

24 Leny Magalhães MRECH, $O$ mercado de saber, o real da educação e dos educadores e a escola como possibilidade, 2001, p. 161.

25 Paulo FREIRE, op. cit. , 2000, p. 127. 


\section{Uma Proposta Metodológica de Intervenção e Pesquisa}

\section{A Pesquisa-AÇÃo: ConCeituaÇão TeÓRICA e Projeto de InTERVEnçÃo}

A conceituação de educação inclusiva, ao longo deste trabalho, tem sido caracterizada como correlata à idéia de educação para todos e foi apresentada tanto a partir do conceito dialético de inclusão/exclusão, quanto como decorrência do processo de disputa pelo acesso ao sistema educacional comum de um grupo que tem sido historicamente objeto da educação especial.

A orientação legalista assegurada pelas diretrizes da educação, que aponta como meta a "inclusão escolar" de todos os alunos, marca o empenho no que se refere à garantia de um ordenamento jurídico positivo ${ }^{1}$. Porém, a forma de organização atual da sociedade encerra características excludentes, e os direitos humanos, para serem efetivados, carecem da defesa de sua legitimidade para seu reconhecimento. Assim, a dialética inclusão/exclusão reflete um processo histórico em constante transformação, que se objetiva nas ações individuais e coletivas no cotidiano da sociedade.

A articulação do conhecimento numa prática coletiva e solidária, adequando os conteúdos e construindo o saber com as experiências de todos, configura-se como uma maneira de possibilitar o enfrentamento dos problemas sociais em busca de sua superação. A inclusão escolar passaria, assim, pelo fortalecimento do lugar institucional dos professores, como protagonistas sociais responsáveis pelo cumprimento da função social da escola. Trabalho contínuo que envolve planejamento, implementação e avaliação na perspectiva de uma atuação mais autônoma frente ao projeto político-pedagógico, possibilitando o reconhecimento e a legitimação no interior da instituição escolar ao direito à educação de todos.

1 Segundo BOBBIO, ordenamento jurídico positivo é o conjunto de normas válidas das quais faço parte como titular de direitos e deveres. Cf. Norberto BOBBIO, op. cit., 1992, p. 15. 
Essa metodologia partiu da premissa do direito indisponível de todos à educação e buscou, sem estereotipar ações, aproximar a lei que se tem com a prática que se quer, utilizando como mote a conceituação, discussão e posterior resignificação do conceito de educação inclusiva.

A proposta de intervenção junto aos educadores no cotidiano da Escola Municipal de Ensino Fundamental Vianna Moog $^{2}$ procurou assegurar um aspecto sistemático para viabilizar, por meio de encontros semanais, o estabelecimento de um espaço referencial de diálogo, subsidiado por teorias e ações, seguindo um formato educativo que possibilitou o debate vivo, o conhecimento mútuo, a reflexão coletiva. Essa ação que, sem dúvida, configurou-se como formação continuada, teve na responsabilidade dos próprios protagonistas seu diferencial. Foi uma atividade que demandou tempo de inserção num espaço já constituído e com movimento próprio escolhido no intuito de aumentar a probabilidade de ininterrupção para além do tempo finito do projeto. A tematização sobre a prática e a preocupação em distanciar-se do senso comum por sua crítica à luz das teorias objetivou a construção de conhecimento por intermédio de um projeto coletivo sob a responsabilidade de todos.

O trabalho artesanal é possível para um representante da universidade que não tem uma receita pronta, mas que promove uma intervenção única a partir da realidade em que estão inseridos seus participantes. Diante das impossibilidades institucionais, é a sinceridade da atuação do intelectual acadêmico que possibilita a criação de brechas e aumenta a possibilidade de recriação do espaço em questão ${ }^{3}$.

2 Cf. Plano Escolar da Escola Municipal de Ensino Fundamental Vianna Moog. Esta escola pertence ao antigo Núcleo de Ação Educativa 12 e, atualmente, à Coordenadoria Educacional do Butantã (CEB). Foi inaugurada aos dezoito de julho de mil e novecentos e oitenta e oito e localiza-se na Rua Francisco Leite Esquerdo, 310 - Jardim Jaqueline - Distrito Butantã, CEP 05528-040 - São Paulo/SP. Sua denominação anterior era "Escola Municipal de Primeiro Grau do Jardim Jaqueline". Recebeu este nome em homenagem a CLODOMIRO VIANNA MOOG (1906-1988), natural do Rio Grande do Sul, formado em Direito no ano de 1930, mesmo ano em que participou da Aliança Liberal, tendo sido contrário à ditadura de Getúlio Vargas. Participou da revolução de 1932, sendo preso e removido para o Amazonas. Foi anistiado pelo Congresso, retornando para o Rio Grande do Sul em 1934. Sua obra mais conhecida é Bandeirantes e Pioneiros (1964), na qual faz uma comparação entre os homens que desbravaram o oeste do Brasil e os que fizeram o mesmo nos Estados Unidos. Foi ainda representante do governo brasileiro na OEA e na ONU (Enciclopédia da Literatura Brasileira - volume II - p. 933).

3 Otávio IANNI, em palestra proferida no seminário "Charles Wright Mills: um sociólogo no centro do capitalismo". São Paulo, Faculdade de Educação da Universidade de São Paulo, 2003. 
O trabalho, fundamentado em metodologias qualitativas de pesquisa em educação, teve como pressuposto que os fenômenos educacionais são bastante complexos e não permitem o isolamento dessa ou daquela variável, mas a focalização do processo de intervenção como um todo, o que, por vezes, torna menos relevante a existência ou não de um "produto ou resultado final". A possibilidade concreta de uma metodologia que aliou intervenção e pesquisa dentro de uma escola pública municipal delineou um trabalho conjunto no qual pesquisadora e pesquisados trabalharam em prol da desconstrução e reelaboração do conhecimento acumulado sobre a realidade em que estão inseridos, tendo como objeto/tema ${ }^{4}$ a educação inclusiva. Criar condições para a elaboração de propostas coletivas acerca de situações apontadas como indesejadas foi a grande motivação e o ponto de maior preocupação desse trabalho.

No caso da metodologia quantitativa há a busca de definir procedimentos bem delineados para evitar a expressão da subjetividade do pesquisador. Já a qualitativa aponta a importância de um trabalho sociológico em que a imaginação do pesquisador esteja presente ${ }^{5}$.

A pesquisa-intervenção assinala uma postura dialética de acordo com a qual a prática é elemento metodológico integrante do processo, "tanto no sentido de servir de teste constante para a validade da teoria quanto no sentido de assumir que a própria pesquisa é uma intervenção na realidade, pois produzimos novo conhecimento neste diálogo com a realidade e nossas conviç̧ões" ${ }^{\prime \prime}$.

A reconstrução do caminho trilhado mostra-se importante para clarear o entendimento sobre como, de fato, se constituiu essa relação entre a escola e a pesquisadora. A primeira questão metodológica que pode ser formulada diz respeito à forma como se deu a escolha do locus de pesquisa, a EMEF Vianna Moog. Pode-se dizer que, no caso, a demanda foi multilateral, ou seja, são passíveis de distinção

40 entendimento metodológico parte do princípio de que todos são sujeitos participantes que têm um objeto ou tema em comum, no caso, a educação inclusiva.

5 Heloisa Helena de Sousa MARTINS, em palestra intitulada "Metodologia qualitativa de pesquisa", proferida durante o seminário Questões teórico-metodológicas na pesquisa em educação na Faculdade de Educação da Universidade de São Paulo, 2003.

6 Pedro DEMO, "Elementos metodológicos da pesquisa participante", 1999, p. 111. 
pelo menos três "quereres" que, relacionados, possibilitaram a execução desse trabalho.

Em primeiro lugar, a formação da pesquisadora e seu interesse pelo estudo do tema educação inclusiva, desde 1999, durante o curso de licenciatura em Psicologia na Faculdade de Educação da Universidade de São Paulo. A investigação sobre o mesmo extrapolou os domínios acadêmicos e foi adquirindo corpo nos mais diferentes locais de atuação: escolas públicas de ensino fundamental, universidades, fóruns, conselho profissional. O caráter pessoal de qualquer pesquisa exige do pesquisador

um envolvimento tal que seu objetivo de investigação passa a fazer parte de sua vida; a temática deve ser realmente uma problemática vivenciada pelo pesquisador, ela deve Ihe dizer respeito. Não obviamente, num nível puramente sentimental, mas no nível da avaliação da relevância e significação dos problemas abordados para o próprio pesquisador, em vista de sua relação com o universo que o envolve. A escolha de um tema de pesquisa, bem como sua realização, necessariamente é um ato político. Também neste âmbito, não existe neutralidade ${ }^{7}$.

Ao mesmo tempo, a idéia de projetos que discutiam a inclusão escolar nas mais diversas formas e sob os mais variados enfoques teóricos vinham ganhando força na Rede Municipal de Ensino. A necessidade de se construir um sistema educacional de qualidade para todos apontada nos documentos legais e oficiais, nacionais e internacionais impulsionava trabalhos nessa perspectiva. O entendimento era o de que seria necessário mais do que um aparato legal para possibilitar a criação de uma ambiência inclusiva ${ }^{8}$, capaz de redefinir papéis e responsabilidades,

7 Antonio Joaquim SEVERINO, Metodologia do trabalho científico, p. 145.

8 A construção de uma ambiência inclusiva no espaço escolar diz respeito à possibilidade da constituição de estratégias para o enfrentamento das questões impostas para a escola no exercício de sua função social. Segundo Aurélio Buarque de Holanda FERREIRA, Novo Aurélio Século XXI: dicionário da língua portuguesa, p. 117, o verbete ambiência refere-se ao "espaço arquitetonicamente organizado e animado, que constitui um meio físico e, ao mesmo tempo, meio estético ou psicológico especialmente preparado para o exercício de atividades humanas". Essa idéia de ambiência agrega ao conceito de ambiente, de caráter eminentemente circunscrito e limitado, a conotação sociocultural. Sua plasticidade reflete o espaço escolar de forma mais fidedigna, pois o caracteriza como constituído a partir de intercâmbios e trocas entre seus agentes e, desta forma, em constante mutação. É justamente esta distinção que potencializa a tarefa a que se propõe este trabalho de abordagem institucional e social. 
no sentido de alterar a realidade educacional do Município e objetivar as diretrizes governamentais locais: democratização do conhecimento e construção da qualidade social da educação, democratização da gestão e democratização do acesso e permanência.

A Escola Municipal de Ensino Fundamental Vianna Moog, por sua vez, já havia tentado implementar um projeto focado no tema educação inclusiva que, pelo término do ano letivo de $1999^{\circ}$, não pôde ser levado a cabo. No segundo semestre de 2001, uma de suas coordenadoras pedagógicas procurou o Núcleo de Ação Educativa, NAE 12, para solicitar uma assessoria sobre esse tema. Como a organização em GAAE - Grupos de Acompanhamento de Ação Educativa ${ }^{10}$ - previa em sua composição um membro da universidade, foi feito contato com a docente responsável pelas aulas de licenciatura em psicologia da Faculdade de Educação da Universidade de São Paulo. Esta declinou do convite e fez a indicação do nome dessa pesquisadora pelo seu envolvimento com o assunto e experiência em trabalhos com escolas.

Num primeiro momento, foi elaborado um pré-projeto, no qual ficavam explicitados os pressupostos teóricos da possível intervenção. Após três encontros entre a representante do setor de Educação Especial do NAE 12, a coordenadora pedagógica da escola e a pesquisadora, foi formalizada a parceria, embora a assinatura do compromisso só tenha sido efetivada no ano seguinte, em 2002, ano em que a intervenção seria desenvolvida.

Feito isto, foram realizados quatro encontros em 2001, no plano preparatório, para apresentar o esboço da proposta para os professores e ouvir deles quais seriam suas indicações para as discussões coletivas a serem desenvolvidas. Os

9 O projeto foi elaborado durante o curso de licenciatura em Psicologia sob a supervisão da Profa. Dra. Leny Magalhães Mrech.

10 A operacionalização de uma articulação maior entre as escolas foi estruturada através da implantação dos GAAE - Grupos de Acompanhamento de Ação Educativa, como já mencionado no capítulo II. As escolas, nos diferentes NAE, seriam primeiramente agrupadas a cada cinco em um POLO pelo critério da proximidade física e, OS GAAE seriam formados por dois integrantes da Equipe Pedagógica do NAE (já alocados por POLO) e um membro da Universidade. A proposta inicial contemplava a realização de um encontro mensal, no mínimo, pelo grupo. 
resultados dessas reuniões iniciais ${ }^{11}$ atingiram plenamente 0 seu objetivo, qual seja, o estabelecimento de um canal mais próximo de comunicação com os protagonistas, a fim de possibilitar uma elaboração conjunta do projeto, responsabilizando todo o coletivo por sua realização e acompanhamento. É importante frisar que esse diálogo promoveu diversas alterações nos projetos em questão: 0 entregue pela pesquisadora para a escola, o Projeto Especial de Ação (PEA) e o Projeto Político Pedagógico, todos constantes do Plano Escolar para 2002.

\begin{abstract}
Embora nosso projeto venha sendo desenvolvido fundamentado na inclusão como princípio básico desde 1999, este "olhar" vem sendo continuamente ampliado e aprofundado, de modo a atender às exigências sociais da comunidade que nos cerca. Inicialmente, o Projeto se baseou na idéia de inclusão de cidadãos portadores de necessidades especiais. Entretanto, no decorrer de seu desenvolvimento, percebemos a necessidade, aliada à possibilidade, de abordar a inclusão de modo mais abrangente, tornando um valor permanente na comunidade escolar a convivência com as diferenças de sexo, cor, religião, crenças, saber, valores e oportunidades sociais. Para tanto, buscamos parcerias com instituições diversas e pessoas físicas, cujo trabalho vem sendo de grande valia para a consecução de nossos propósitos [...] receberemos assessoria específica para o desenvolvimento deste Projeto de Inclusão junto aos educadores ${ }^{12}$.
\end{abstract}

Segundo o Plano supracitado, a escola ressalva que o cumprimento de sua função social é

a construção do conhecimento e a garantia do acesso ao conhecimento socialmente produzido. Nossa proposta pedagógica é o comprometimento com o despertar da consciência, da cidadania crítica e atuante. A escola continua a passar por constantes modificações nos procedimentos internos, de modo a adequá-los às necessidades do cotidiano, bem como vem trabalhando pela implementação de seus princípios regimentais ${ }^{13}$.

Com respeito ao nível socioeconômico da clientela, oriunda em sua maioria da favela do Jardim Jaqueline, descreve-o como predominantemente baixo,

11 É importante destacar que o horário destas conversas iniciais foi planejado dentro do horário de trabalho coletivo com vistas a - caso a proposta fosse aprovada pelo coletivo - possibilitar uma continuidade do processo no ano de 2002.

12 Escola Municipal de Ensino Fundamental Vianna Moog, Plano Escolar de 2002, p. 37.

13 Idem, ibidem. 
apontando que $50 \%$ a $60 \%$ dos alunos não traziam os materiais escolares solicitados. Outro fator destacado nesse item é a não-participação dos pais e/ou responsáveis, atribuída a motivos ligados ao trabalho e/ou desinteresse com a vida escolar de seus filhos. Apenas $10 \%$ são considerados pela escola como atuantes. Essa desmobilização é apontada como fator de enfraquecimento tanto da Associação de Pais e Mestres como do Conselho de Escola, embora os dois estejam estruturados e completos, de acordo com a lei vigente e atuando para "o bom andamento das atividades pedagógicas ${ }^{\prime 14}$.

Os Órgãos Associação de Pais e Mestres - APM e Conselho de Escola - C.E. seriam mais eficazes, caso houvesse uma maior participação da comunidade e um maior envolvimento de alguns membros, que muitas vezes, se acomodam em decisões alheias, deixando assim, de assumir suas funções ${ }^{15}$.

Outro aspecto relevante no que diz respeito à gestão é o estabelecimento do Grêmio Estudantil ${ }^{16}$. Seu processo de implantação foi desencadeado pelas equipes técnica e docente durante o período de planejamento ${ }^{17}$, no início do ano letivo, por considerarem que o fato de se tratar de ano eleitoral despertaria maior interesse por esse tipo de procedimento e ainda pelo fato de esta ser uma prioridade da gestão municipal.

Acreditamos que o Grêmio Estudantil se constitui em importante instituição escolar capaz de propiciar o avanço democrático da sociedade, através da organização da participação dos alunos. Trata-se de oportunizar iniciativas que podem reforçar e contribuir para o trabalho pedagógico e cabe à comunidade escolar estimular esta agremiação, em direção de um trabalho coletivo que envolva, inclusive, as outras instâncias de gestão da escola, com a Associação de Pais e Mestres e o Conselho de Escola ${ }^{18}$.

14 Idem, p. 11.

15 Idem, ibidem.

16 Após eleição, ocorrida aos 6 de setembro de 2002, foi instituído o Grêmio "União Estudantil", que se encontra em processo de elaboração de seu Estatuto. Todos os procedimentos relativos a esta ação estão registrados em Livro Oficial da Escola.

17 A Secretaria Municipal de Educação estabelece um período de três dias estipulados para a elaboração do planejamento escolar que deve constar do Calendário Escolar oficial a ser assinado pela diretora da unidade, pelo supervisor escolar e pelo coordenador do NAE 12.

18 Idem, p. 20. 
O aproveitamento didático-pedagógico mais satisfatório de todos os alunos matriculados ${ }^{19}$ parece, então, ser a idéia mestra das ações desenvolvidas pela EMEF, expressa na frase "A inclusão como princípio básico", título do projeto políticopedagógico da mesma.

\begin{abstract}
A criança e o adolescente gozam de todos os direitos fundamentais inerentes à pessoa humana, sem prejuízo da proteção integral de que trata esta Lei, assegurando-se-lhes, por lei, ou por outros meios, todas as oportunidades e facilidades, a fim de lhes facultar o desenvolvimento físico, mental, moral, espiritual e social, em condições de liberdade e de dignidade $e^{20}$.
\end{abstract}

As assessorias, parcerias e outras formas de aprofundamento de conhecimentos e aprimoramento do atendimento dos alunos foram planejadas e pormenorizadas no Projeto Político-Pedagógico. O curso de LIBRAS, em continuidade ao trabalho realizado em 2001; a interlocução com o Posto de Saúde do Jardim Jaqueline, principalmente na área de Saúde Bucal; o trabalho conjunto com o Centro de Participação Educacional e Comunitária Clarisse F. Wey - CEPEC, que disponibilizou profissionais para aulas de reforço destinadas a alunos do segundo ao quarto anos do Ciclo I que apresentam dificuldades relacionadas à alfabetização; a

19 A organização por ano/turno na EMEF para o ano de 2002 estava estruturada da seguinte forma: 10 Turno (das 07:00 às 11:00 horas) com 328 alunos assim divididos: Ciclo I: quatro classes de $1^{0}$ ano ( $A, B, C$ e D) com um total de 157 alunos, uma classe de $2^{\circ}$ ano (A) com quarenta alunos e quatro classes de $4^{\circ}$ ano (A, B, C e D) com um total de 131 alunos; $2^{\circ}$ Turno (das 13:00 às 17:00 horas) com 330 alunos assim divididos: Ciclo I: uma classe de $2^{\circ}$ ano (B) com 38 alunos e duas de $3^{\circ}$ ano (A e B) com um total de 79 alunos e no Ciclo II: duas classes de $1^{\circ}$ ano ( $5^{\mathrm{a}} \mathrm{A}$ e B) com um total de 76 alunos, três de $2^{\circ}$ ano $\left(6^{\mathrm{a}} \mathrm{A}, \mathrm{B}\right.$ e $\left.\mathrm{C}\right)$ com um total de 101 alunos e uma de $3^{\circ}$ ano $\left(7^{\mathrm{a}} \mathrm{A}\right)$ com 36 alunos; $3^{\circ}$ Turno (das 19:00 às 23:00 horas) com 326 alunos assim divididos: Ciclo II: uma classe de $3^{\circ}$ ano (7aB) com dezoito alunos, uma classe de $4^{\circ}$ ano $\left(8^{\mathrm{a}} \mathrm{A}\right)$ com 28 alunos. É necessária uma observação que houve um remanejamento destes alunos do diurno para freqüentarem o período da noite, apesar de terem apenas catorze anos com a respectiva condição da autorização dos pais. Ainda com relação ao $3^{\circ}$ turno, existem as turmas de Ciclo II - EJA (Educação de Jovens e Adultos) uma classe de cada termo no primeiro semestre $-1^{\circ} \mathrm{com}$ trinta alunos, $2^{\circ} \mathrm{com}$ quarenta alunos, $3^{\circ} \mathrm{com}$ 29 alunos e $4^{\circ}$ com 39 alunos, num total de 138 alunos no primeiro semestre e, uma classe de cada termo no segundo semestre $-1^{\circ}$ com 35 alunos, $2^{\circ}$ com 37 alunos, $3^{\circ}$ com 41 alunos e $4^{\circ}$ com 29 alunos, num total de 142 alunos no segundo semestre - total para o ano letivo de $2002-280$ alunos nesta modalidade. A EMEF teve, no ano de 2002, 984 alunos matriculados.

20 Lei n. 8.069 de 13 de julho de 1990 que dispõe sobre o Estatuto da Criança e do Adolescente, cujo artigo $3^{\circ}$ foi posto como epígrafe no Projeto Político-Pedagógico da EMEF Vianna Moog de 2002, p. 37. 
parceria com o Balneário "Mário Moraes", da Secretaria Municipal de Esportes (SEME), que atende à comunidade local e, no caso dos alunos, oferece aulas de educação física para crianças do Ciclo I.

Algumas dessas propostas foram expressas no Projeto Especial de Ação inserido no Plano Escolar, a exemplo do Projeto de Inclusão, como já mencionado. Cabe explicitar, porém, que para cada cargo constante do quadro de pessoal ${ }^{21}$ há um Plano de Ação específico. Destes, vale a pena destacar alguns pontos daqueles relativos à Coordenação Pedagógica. Como tarefa primeira dessa função, é apontada a responsabilidade pela articulação entre os ciclos, levando em conta suas especificidades, para garantir uma educação democrática, tendo em vista o acesso e a permanência dos alunos na escola, a formação coletiva do conhecimento e sua veiculação. Suas tarefas cotidianas englobam: coordenar os grupos de formação; orientar alunos, professores e pais; visitar as salas de aula; garantir o Projeto Político-Pedagógico; e intermediar o diálogo entre os professores e a direção da escola.

\begin{abstract}
Acreditamos que a construção dessa escola demanda uma compreensão integrada da realidade, possível através do processo de ação-reflexão-ação de maneira contínua e coletiva. [...] Nosso maior desafio é colocar aos educadores a realização de uma escola democrática através de sua competência técnica dirigida às classes populares, como instrumento de luta contra a marginalização e seletividade dos alunos. Este "fazer" vai ao encontro da autonomia da escola, de modo que esta seja capaz de encontrar novas alternativas de ensino e de aprendizagem, possibilitando a participação dos pais e da comunidade em geral neste processo de transformação ${ }^{22}$.
\end{abstract}

O Projeto Especial de Ação, de acordo com a Portaria n. 3.826 de $1997^{23}$, está expressamente subordinado ao Projeto Político-Pedagógico da escola e caracteriza-se como instrumento voltado à melhoria do processo de ensino-

210 quadro de pessoal da EMEF era composto à época (2002) pelos seguintes profissionais: uma diretora de escola, um assistente de diretor, duas coordenadoras pedagógicas, uma secretária de escola, um agente técnico II (auxiliar de secretaria), dois agentes técnicos I (inspetores de alunos) e oito agentes escolares.

22 Escola Municipal de Ensino Fundamental Vianna Moog, Plano Escolar de 2002, pp. 45-46.

23 Conforme detalhado no capítulo II, p. 57. 
aprendizagem e de natureza pedagógico-institucional. Foram transcritos a justificativa, os objetivos e as metas e os resultados esperados dessa proposta unificada, que traduz de forma completa como a escola pretendia, coletivamente, realizar seu Projeto.

\author{
PROJETO ESPECIAL DE AÇÃO/PEA \\ I - JUSTIFICATIVA: \\ - Necessidade de oferecer suporte teórico e facilitar a troca de experiências \\ entre os docentes e coordenadores.
}

- Para que o PPP aconteça, efetivamente, é fundamental o desenvolvimento, ao longo do ano, de encontros coletivos com objetivos claros e definidos.

- Necessidades apontadas, a partir da avaliação contínua.

- Diagnóstico da realidade.

- Possibilitar a reflexão do professor no sentido de este incluir-se como parte na avaliação dos sucessos ou insucessos de alunos avaliando, assim, os seus processos de ensino.

- Trabalhar com a comunidade no sentido de que a mesma se integre ao processo de educação escolar.

II - OBJETIVOS E METAS:

- Sensibilizar os professores da U.E. para compreender as bases da Educação Inclusiva e aprofundar os conhecimentos dos que já foram sensibilizados

- Que os docentes sejam capazes de facilitar a busca da autonomia dos nossos alunos, contribuindo para a construção do seu conhecimento.

- Integrar os conteúdos das diversas áreas do conhecimento, utilizando a informática ${ }^{24}$ educativa para aprofundá-los.

- Integrar o trabalho desenvolvido na Sala de Leitura e no Laboratório de Informática.

- Integrar comunidade e escola.

- Criar mecanismos para o desenvolvimento de uma cultura colaborativa na escola em que a reflexão do próprio trabalho seja um dos componentes.

- Criar estratégias didáticas próprias para formação de professores e lhes apontar caminhos para eventuais mudanças.

- Contribuir para a alfabetização de todos os alunos, na perspectiva da inclusão.

- Aprofundar estudos sobre as estratégias de avaliação do rendimento escolar.

IV - RESULTADOS ESPERADOS:

- Que todos os educadores da Unidade Escolar se voltem prioritariamente para a questão da alfabetização, tanto em sentido amplo, quanto em

24 A multiplicação em Informática Educativa terá a orientação dos POIE - Professores Orientadores de Informática Educativa da unidade escolar. Do ponto de vista de apoio material, a escola contou com a parceria firmada entre a Telefônica e a Prefeitura de São Paulo, que instalou o novo Laboratório de Informática, com conexão para "internet" inaugurada em 2001. 
sentido restrito, tendo como resultado esperado tanto a leitura de mundo quanto a compreensão das mensagens dos diversos portadores de texto; - Que todos os educadores se empenhem na superação das dificuldades de alfabetização que o processo de aprendizagem traz;

- Que a idéia de inclusão permaneça presente no cotidiano da U.E., ampliando o "novo olhar" de si próprio e dos outros, construído ao longo do desenvolvimento do Projeto;

- Que a convivência com as diferenças de sexo, cor, saber, crenças, valor etc se torne cada vez mais um valor permanente na comunidade;

- Que a U.E. solidifique seu trabalho em informática educativa;

- Que a comunidade perceba a escola sendo sua ${ }^{25}$.

O caráter metodológico estruturado a partir da entrada da pesquisadora no cotidiano institucional está referenciado nos documentos escolares. Destarte, assim como os direitos humanos dizem respeito a conquistas a serem legitimadas socialmente, o trabalho coletivo, legalizado pela objetivação das diretrizes da escola e do Município em seus aparatos, foi consubstanciado na postura dos envolvidos. A responsabilidade ética do pesquisador configurou-se na construção de conhecimento para possibilitar o aparecimento de outras respostas e novas questões e não para apontar as mazelas e os equívocos da escola desvendadas pelo olhar acadêmico científico. A construção de um objeto de conhecimento comum, já escolhido por ambos, partiu da valorização do que já havia previamente sido acumulado pelos participantes ao longo da história da escola. A escola exclui e inclui o tempo todo e, portanto, todos têm algo a dizer quando esse é o assunto. Essa relação com os protagonistas da tarefa escolar, como conhecedores práticos e teóricos, foi fundamental para a criação de uma base de respeito mútuo para que as questões ético-políticas pudessem ser debatidas.

Se [...] a minha opção é libertadora, se a realizada se dá a mim como algo parado, imobilizado, posto aí, mas na relação dinâmica entre objetividade e subjetividade, não posso reduzir grupos populares a meros objetos de minha pesquisa ${ }^{26}$.

25 Escola Municipal de Ensino Fundamental Vianna Moog, Plano Escolar de 2002, pp. 55, 58 e 59. 26 Paulo FREIRE, "Criando métodos de pesquisa alternativa: aprendendo a fazê-la melhor através da ação", 1985, p. 35. 
O recorte microsociológico, como o estudo em uma escola, facilitou o trabalho de pesquisa-ação na superação da ciência como dogma, por meio do desenvolvimento de hábitos de ação potencializados pelo coletivo. $E$, na medida em que o projeto foi sendo delineado pelos participantes, ficaram explícitos o dinamismo do fenômeno educacional e a realidade complexa do dia-a-dia escolar.

\begin{abstract}
A pesquisa qualitativa objetiva, em geral, provocar o esclarecimento de uma situação para uma tomada de consciência pelos próprios pesquisados dos seus problemas e das condições que os geram, a fim de elaborar os meios e estratégias para resolvê-los ${ }^{27}$.
\end{abstract}

O objetivo dessa primeira etapa foi, assim, transformar o que existia como problema ou questão unilateral em uma proposta coletiva de trabalho, bem como concretizar o cronograma para a realização do projeto. Levando em consideração que a maioria dos professores que se dispuseram a participar do projeto ${ }^{28}$, determinou que a quinta-feira seria o melhor dia da semana para esse propósito, ficou acordado que seriam realizados encontros sistemáticos no dia proposto, em dois horários ${ }^{29}$ - diurno e vespertino - de forma a utilizar as horas de trabalho coletivo. O fechamento do calendário teve como principal preocupação desenvolver o projeto com o maior número de participantes possível. Daí a oferta de dois horários para possibilitar a presença de professores representantes de todos os ciclos.

No que concerne à metodologia, segundo a perspectiva de pesquisa qualitativa em educação, o entendimento da pesquisa-ação foi fundamental no direcionamento deste trabalho. Durante o processo, foi desenvolvida a dupla função de observador crítico e de participante ativo que dispõe de sua experiência e saberes acumulados, por meio dos instrumentos científicos disponíveis, a serviço da construção de uma ambiência inclusiva no espaço escolar.

A pesquisa ação se propõe a uma ação deliberada visando uma mudança

27 Antonio CHIZZOTTI, Pesquisa em ciências humanas e sociais, 1995, p. 104.

28 A escola, no ano de 2002, tinha 55 funcionários, sendo 32 professores em exercício, isto é, em sala de aula.

29 A intervenção era feita às quintas-feiras, ocupando duas horas-aula em cada período. Na parte da manhã, ocorria das $11 \mathrm{~h} 05$ às $12 \mathrm{~h} 35$ e no período vespertino, das $17 \mathrm{~h} 25$ às $18 \mathrm{~h} 55$. 
no mundo real, comprometida com um campo restrito, englobada por um projeto mais geral e submetendo-se a uma disciplina para alcançar os efeitos do conhecimento ${ }^{30}$.

A inserção no grupo de professores e técnicos, como momento significativo da pesquisa-ação, foi sendo aprimorada ao longo de todo o projeto, sendo facilitada pela explicitação de demanda originária das três instâncias envolvidas: a pesquisadora (como representante do "saber universitário e científico"), a escola e o poder público. Quanto à temática geradora, a educação inclusiva, nos três casos ela já vinha sendo discutida. É importante salientar que a riqueza dessa metodologia reside justamente no fato de que as etapas não ocorrem apenas uma vez durante 0 processo. Ao contrário, geram um moto contínuo de coleta de dados, discussão, ação, nova coleta, mais discussão, nova ação, e assim sucessivamente, possibilitando a construção, e não a imposição, de conhecimento e consciência para que os professores possam potencializar sua experiência cotidiana e, conseqüentemente, seus lugares de protagonistas da ação educativa.

Ao invés de se preocupar somente com a explicação dos fenômenos sociais depois que eles aconteceram, a finalidade da pesquisa/ação é de favorecer a aquisição de um conhecimento e de uma consciência crítica do processo de transformação pelo grupo que está vivendo este processo, para que ele possa assumir, de forma cada vez mais lúcida e autônoma, seu papel de protagonista e ator social ${ }^{31}$.

Por intermédio do mote da conceituação, discussão e posterior resignificação de um objeto de conhecimento comum, os participantes poderiam exprimir seus pensamentos, suas experiências e suas contradições concernentes ao cotidiano escolar. A construção de conhecimento significativo para o coletivo da instituição teria a função de possibilitar ao grupo a explicitação de forma mais aprofundada das questões que vinham sendo enfrentadas. $E$, nesse sentido, trabalhar na elaboração de estratégias dentro das possibilidades de ação, incorporadas sistematicamente no projeto político-pedagógico, delegando ao grupo a

30 Antonio CHIZZOTTI, op. cit., p. 100.

31 Rosiska Darcy de OLIVEIRA e Miguel Darcy de OLIVEIRA, "Pesquisa social e ação educativa: conhecer a realidade para poder transformá-la", 1985, p. 27. 
responsabilidade pela gestão da unidade escolar, desde seu planejamento até a avaliação.

As propostas do ponto de vista metodológico, da pesquisa, da escola e da gestão municipal destacam a importância do processo de ação-reflexão-ação na elaboração de conhecimento e enfatizam que é no curso da própria ação que se dá a reflexão para a reformulação da ação para novas situações. Entendem que o conhecimento reproduzido nas escolas, resultado de todo o acúmulo de experiências, pode e deve ser repensado cotidianamente. A partir de uma experiência onde está posta a viabilidade de (des)construção de determinado conhecimento, legitima-se tal procedimento. Além disso, a utilização do horário coletivo de trabalho pedagógico proposto no contexto escolar, entendido como espaço conquistado historicamente pelos protagonistas e referendado pelo sistema, permite, de certa forma, uma subversão revolucionária, no sentido de utilizar as "brechas" do sistema para criticar o próprio sistema. Essa lógica permite considerar a escola como locus privilegiado de formação ético-política e como espaço de transformação, para além da reprodução e da informação, com posicionamentos e participações coletivizados.

\section{A INTERVENÇÃO: O ANO LETIVO DE 2002}

A incorporação da etapa preparatória no Projeto Político-Pedagógico sob a forma de Plano Especial de Ação, descrita anteriormente, evidenciou uma postura que foi respeitada durante todo o processo, qual seja, a de sistematizar nos documentos oficiais da instituição todas as ações e de delegar ao grupo a responsabilidade pela continuidade das etapas de planejamento, implementação e avaliação, reconhecendo e legitimando no interior da instituição escolar o direito à educação de todos.

A proposta, do ponto de vista metodológico, destacou a importância do processo de ação-reflexão-ação para a construção de determinado conhecimento, no sentido de validar tal procedimento e distinguir a escola como locus privilegiado de 
formação ética, política e espaço de transformação. A realimentação de ações como forma de repensar opções políticas e programáticas denota a apreensão de seus elementos como articulados e inseridos numa dinâmica de ações contextualizadas em espaço e tempo determinados. O relato a seguir não tem como objetivo mostrar a intervenção de forma isolada, como se fora um apanhado de objetivos, estratégias e resultados estipulados a priori, mas como o movimento da ação foi construído no espaço coletivo. Essa postura ético-política da pesquisadora implicou a necessidade de adaptação constante do projeto à realidade concreta da EMEF Vianna Moog, e não o contrário, sem abrir mão dos acordos firmados anteriormente.

Logo no início do trabalho, no ano letivo de 2002, foi solicitado que, pelo fato de a reunião no horário de trabalho coletivo tratar-se de momento no qual as coordenadoras pedagógicas participavam ativamente, houvesse a dedicação de mais duas horas-aula na parte da manhã e outras duas na parte da tarde para discussões com cada uma delas separadamente. Nessas reuniões específicas com as coordenadoras, uma das tarefas ordinárias tratava da estruturação dos horários de trabalho coletivo subseqüentes, de acordo com os pontos de pauta previamente encaminhados pelo grupo. Uma segunda, menos explícita, consistia em entender como estavam dispostas as ações escolares no sentido do cumprimento do Projeto Político-Pedagógico, uma das funções mais caras da coordenação, como já mencionado. Nesses encontros, pouco a pouco, foi ficando mais clara qual a dinâmica da escola. Por exemplo, em razão das disponibilidades de horário e das escolhas pessoais, a instituição era dividida em duas: uma de ciclo I e outra de ciclo II e EJA, sendo que cada "metade" era atendida por uma das coordenadoras. Essas, com pouco tempo para trocarem suas experiências diárias, apesar dos esforços, tinham atuações, por vezes, isoladas, embora concernentes ao Projeto PolíticoPedagógico. No que se refere ao "projeto de inclusão", essa dinâmica, inicialmente, atribuiu a responsabilidade do mesmo à coordenadora do ciclo I, que fez os primeiros contatos com o NAE 12. Havia um entendimento tácito de que a proposta refletia, portanto, uma demanda de apenas de um dos ciclos, o que, inicialmente, implicou uma atuação reticente por parte da coordenadora responsável pelos outros ciclos. Este modo peculiar do funcionamento da instituição não ficou patente nos 
primeiros encontros, mas foi explicitado ao longo das discussões e pelas falas das próprias coordenadoras, dos professores, da direção, impondo que a proposta, para além do que havia sido estabelecido, contemplasse, também como norte de ação, promover discussões comuns e relevantes a todos, no sentido de possibilitar uma "aproximação" paulatina entre os ciclos para, assim, agir em busca da construção de uma unicidade, minimizando os ruídos de comunicação. Esses encontros foram imprescindíveis para dar forma e conteúdo a essa disposição.

Nesse período, foram realizadas também algumas reuniões com o Núcleo de Ação Educativa 12, cuja pauta constava sempre de dois objetivos principais: discutir o andamento do processo e ajustar burocraticamente algumas questões pendentes. Nessas, havia sempre a presença de alguns representantes da escola, ora da direção, ora da coordenação, ora de ambas, fortalecendo, de alguma forma, o tripé que demandou a intervenção.

Cada encontro durante o horário de trabalho coletivo propriamente dito resultava numa ata, documento público passível de consulta por todos aqueles que tivessem interesse, participantes ou não do projeto ${ }^{32}$. Essa preocupação do registro permeou todo o processo, não apenas pelo motivo acima mencionado, como ainda para que $o$ andamento das reuniões pudesse ser eficiente. Os apontamentos englobavam desde a montagem coletiva da pauta do encontro ulterior, feita a partir de uma breve avaliação no final de cada reunião, até o resumo do que havia sido discutido e deliberado coletivamente, quais as tarefas pendentes etc., de forma que cada encontro era iniciado com a retomada da ata anterior, caracterizando a processualística adotada.

A análise dessas reuniões foi realizada utilizando-se esse material de consulta, ou seja, as próprias atas e alguns relatórios pessoais elaborados no final de cada encontro. Para possibilitar uma forma de detalhamento do projeto que preservasse a noção da dinâmica de seu desenvolvimento, o processo será dividido em três momentos: conceituação de educação inclusiva, elaboração de projetos de curta duração e (re)discussão do Projeto Político-Pedagógico da EMEF Vianna Moog.

32 As atas encontram-se na Escola Municipal de Ensino Fundamental Vianna Moog. 
A partir da formação do grupo ${ }^{33}$, que era diferente tanto daquele que participou da elaboração do projeto em 2001 quanto do que estava presente no período de planejamento no início do ano letivo de 2002, a etapa chamada de conceituação de educação inclusiva privilegiou, concomitantemente, o aprimoramento sistemático do projeto, a forma de trabalho adotada e a discussão de alguns conceitos no sentido da clarificação dos valores ${ }^{34}$ envolvidos e da construção conceitual $^{35}$ do tema central.

Assim, as reuniões versavam sobre leitura e discussão do projeto e dos textos propostos sobre o tema "inclusão", que constavam da bibliografia básica ${ }^{36}$ do concurso para professores municipais ocorrido no final do ano de 2001. Visava-se à construção de um consenso possível, ainda que momentâneo, sobre o objeto de estudo e a proposta como um todo.

A leitura dos textos, no início, foi uma tarefa que suscitou muita contrariedade por parte dos participantes, que alegavam falta de tempo, desinteresse pelo assunto e necessidade de uma intervenção mais ligada à prática. Como já citado, o projeto se propôs a ser flexível, procurando sempre se adaptar ao funcionamento da escola, e não o contrário. Porém, o entendimento de que o contato com os textos era condição sine qua non para que o grupo pudesse construir conhecimento coletivo, a partir do elaborado por alguns autores que já haviam se dedicado ao assunto em pauta, fez com que essa empreitada não fosse suspensa. 0 entendimento era o de que o reforço dessa tarefa de resgate das idéias socialmente construídas, uma das funções básicas dos professores, tanto fortalecia o elo entre teoria e prática como revitalizava a potência da postura dos próprios protagonistas. A dificuldade de os participantes lerem os textos com antecedência e esse entendimento de que o contato com os diversos autores representantes de "olhares"

33 Para esta etapa foi convidada para participar da consolidação do projeto na escola a pedagoga Maria Claudia Junqueira. A idéia principal era a de que o trabalho em dupla possibilitaria um diálogo mais profícuo com a instituição e seus protagonistas. Além dela e da pesquisadora, os grupos eram abertos, sendo freqüentados mais sistematicamente pelos professores optantes da JEI, por uma coordenadora pedagógica - no mínimo - e por um representante da direção (auxiliar, vice-diretora e/ou a própria diretora).

34 Cf. Josep PUIG, Ética e valores: métodos para um ensino transversal, 1998, pp. 37-44.

35 Cf. Idem.

36 Todos os livros trabalhados com os professores compõem o texto desta dissertação. 
sobre o tema e, de certa forma, tradutores do embasamento teórico que permeava a elaboração das diretrizes municipais, uma vez que compunham a parte bibliográfica do concurso, conduziram a várias dinâmicas de leitura coletiva e troca de idéias. 0 tempo de permanência em cada texto variou muito de acordo com as discussões estabelecidas em cada grupo, que ora foram muito semelhantes, ora bem diferentes. Em sua heterogeneidade, cada grupo trouxe, ao longo desse período, várias questões que tocavam o tema e o aproximavam do cotidiano da escola. Os conteúdos das discussões dos grupos, além de constarem das atas, eram socializados entre os mesmos, pois o objetivo era formar um conceito coletivo de educação inclusiva para a EMEF Vianna Moog. Além dos textos disparadores ${ }^{37}$, eram trazidas as discussões sobre o tema que estavam acontecendo em vários lugares fora da escola, como no Fórum Permanente de Educação Inclusiva, Fóruns Estadual e Nacional em Defesa da Escola Pública. Além disso, foi aberta a possibilidade de participação em várias dessas instâncias para os que se interessassem.

Ao mesmo tempo, os documentos escolares eram revistos, tendo seus conteúdos como centro de várias discussões. Essa foi uma forma de sociabilizar o que estava posto como objetivo da instituição (e que, de algum modo, não era compartilhado por todos do mesmo jeito) e de imbricar a discussão sobre educação inclusiva constante do Projeto Político Pedagógico da escola. Alguns professores, inclusive, após "tomarem conhecimento" desses instrumentos, colocaram como proposta a divulgação dos mesmos entre os alunos. O discurso da falta de tempo para leitura foi sendo dirimido com a abertura de espaços de leitura durante 0 próprio horário coletivo de trabalho.

De maneira ora mais acalorada, ora menos, as discussões foram trazendo um certo descontentamento com o projeto, não especificamente com o que estava sendo desenvolvido, mas em relação à idéia mais geral do ingresso de alunos com

37 Os textos utilizados foram: Maria Teresa Eglér MANTOAN, "Introdução" In M. T. E. MANTOAN e cols., A integração de pessoas com deficiência: contribuições para uma reflexão sobre o tema, 1997, pp. 6-9. Bader SAWAIA, "O sofrimento ético-político como categoria de análise da dialética exclusão/inclusão". In B. SAWAIA (org.) As artimanhas da exclusão: análise psicossocial e ética da desigualdade social, 2001, pp. 96-118. Paulo FREIRE, "Denúncia, anúncio, profecia, utopia e sonho". In P. FREIRE, Pedagogia da indignação: cartas pedagógicas e outros escritos, 2000, pp. 117-134. 
necessidades educacionais especiais, cujas justificativas eram as condições de infraestrutura da escola e a falta de formação adequada dos professores. Os argumentos centravam-se no fato de que nem a instituição nem seus protagonistas sentiam-se preparados para tal função, colocada sempre como além da tarefa pedagógica. Quando questionados, então, se a proposta do grupo de professores do Vianna Moog era pela não entrada desses alunos da escola, a resposta era negativa. Havia, notadamente, uma discrepância entre os discursos dos participantes que, dependendo do momento, utilizavam-se de "registros" diferentes: "aquilo que devo falar", "aquilo que penso" e "aquilo que me sinto capaz de fazer". A dedicação cada vez maior sobre o tema possibilitava lentamente uma aproximação mais harmônica entre esses aspectos, construída no coletivo. Quais eram os alunos que freqüentavam a escola que se "encaixavam" na descrição de "aluno com necessidade educacional especial", quais eram essas necessidades e que providências a escola vinha tomando para atendê-los? Essas perguntas mobilizaram os professores, pois, de certa forma, suas respostas representariam uma possibilidade concreta de "aplicar" o que estava sendo discutido. O grupo começou a fazer algumas propostas e a buscar novas respostas. No bojo desse debate sobre inclusão, vários outros conceitos como exclusão, preconceito, estereótipo, deficiência, fracasso escolar, indisciplina e felicidade pública foram discutidos, ampliando o enfoque para além do atendimento de alunos com necessidades educacionais especiais ${ }^{38}$, tudo com o intuito de disponibilizar para os professores as referências mais atualizadas sobre o tema.

A pergunta-chave passou a ser, quem, afinal, são os excluídos do Vianna Moog. Dentre as respostas, apareceram desde os alunos com deficiências matriculados na escola, os que não conseguiam participar do processo de aprendizagem a contento, até os próprios professores, que expressaram seu sentimento de exclusão.

38 O desenvolvimento destes conceitos nos capítulos precedentes procurou contemplar todas as discussões realizadas pelo grupo. 
No final desse período, em meados de abril, retomaram-se todos os textos e exibiu-se o filme Colcha de $\operatorname{Retalhos}^{39}$ durante a reunião pedagógica, na qual a presença é obrigatória para todos os professores da escola. Isto serviu para que os docentes que não compunham o grupo pudessem colocar suas questões a respeito do que estava sendo apresentado. Esse momento foi uma solicitação da própria coordenação, com a anuência da direção e dos professores participantes, e, por esse motivo, foi feita nos três períodos, para que fossem atingidos todos os agentes do Vianna Moog, docentes ou não.

Uma observação importante deve ser apontada quanto à "resposta comum" formulada pelos professores em relação à sua falta de preparo para atender "alguns alunos": o encaminhamento. A presença de uma "especialista" na escola viria ao encontro dessa solicitação de "ajuda". Esses primeiros meses caracterizaram-se, então, pela insistente solicitação de atendimento desses alunos e pelo assinalamento sistemático dessa demanda, respaldado pelo aporte teórico da intervenção. Entretanto, ouvir e analisar esses pedidos auxiliou deveras no entendimento da noção dos professores sobre quais efetivamente eram os alunos que apresentavam "problemas" geradores de encaminhamentos para "atendimento especializado". A explicitação desses pedidos revestidos de argumentos queixosos, centrados na tônica de uma assistência individual e psicológica ao aluno, possibilitou tornar público, durante os encontros coletivos, o entendimento de vários participantes de que a solução para algumas das dificuldades escolares estaria em delegar para um profissional, de preferência ligado à saúde, o atendimento de alguns "casos". De certa forma, os alvos dos encaminhamentos seriam justamente aqueles alunos que, por inúmeras razões nem sempre objetivadas, eram passíveis de um tipo "sutil" de exclusão escolar, por vezes encoberto por um discurso assistencialista de uma melhor forma de atendimento às suas supostas necessidades.

39 Colcha de Retalhos - "How to make an American Quilt" (1995) - drama - 115 minutos - 14 anos Universal Pictres - Produção AMBLIN Entertainement - um filme de Jocelyn Moorhouse, produção de Sanford/Pillsbury. Sinopse: uma universitária de Berkeley está passando o verão na casa de sua avó e sua tia. A casa delas seria um refúgio calmo onde a garota pretendia terminar sua tese e pensar numa proposta de casamento. Conta encontros e desencontros da vida de várias mulheres que se reúnem para fazer uma colcha de cama utilizando a técnica de patchwork, onde os trabalhos individuais dão a forma do coletivo. 
Como já discutido, dar apoio é essencialmente diferente de fazer encaminhamento, pois o primeiro parte do pressuposto da modificação da escola para viabilizar o acesso e a permanência de todos os alunos, na perspectiva da inclusão, enquanto o segundo parte de uma premissa de segregação ou de integração segundo a qual o foco da mudança é o próprio aluno, no sentido de se melhor adaptar à instituição escolar. Além disso, o comprometimento e a responsabilidade do professor e da escola nesse enfoque são apenas de elaboração de um primeiro "diagnóstico" a ser confirmado e tratado por outrem. O bloqueio desta via desviou a pressão para a aquisição de conhecimentos que resolvessem os problemas desses alunos, uma vez que eles já estão na sala de aula, por vezes "atrapalhando" o seu bom andamento. Como fazer um "bom" diagnóstico das razões pelas quais determinados alunos não aprendem? Como entender das principais patologias que acometem as crianças em idade escolar? Como "descobri-las" a tempo para que tenham um bom "prognóstico" e seu processo de "cura" menos penoso? A inviabilização desse caminho pela explicitação das características de uma intervenção institucional, cujas ações tinham como base os pressupostos da inclusão e não da segregação ou da integração, foi aumentando lentamente a possibilidade de que o coletivo se mobilizasse no sentido de procurar novos tipos de resposta para as questões que se impunham no dia-a-dia, mesclando novas respostas aos pressupostos mais solidificados.

Destarte, a pesquisa-ação, pelo exposto, não se limitou a colher informações e opiniões do grupo - expectativas e representações acerca da ação - e a "classificar" sob quais paradigmas estavam estruturadas as perspectivas dos protagonistas, mas, por intermédio do envolvimento dos participantes nos embates coletivos, construir disponibilidade dos protagonistas para vislumbrar outras formas de atuação e de apoio para sua efetivação.

Tomar a escola como um lugar laico permeado por contratos humanos trouxe a responsabilidade de criar novas conexões para mudar o que se considerava indesejado, e determinou ter como ponto de partida o que efetivamente vinha sendo discutido e realizado, a despeito de partes desse conteúdo já estarem colocadas tanto nos registros oficiais da U.E. como nas diretrizes para a educação do Município, 
como se fora consenso. Essa revisão constante do conhecimento a partir da análise coletiva das colocações individuais, teóricas e experienciais aumentaria a possibilidade de alterações significativas nos pressupostos práticos e no empenho pelo desenvolvimento de novos modos de organização do trabalho pedagógico que culminam em ações compartilhadas para interferir na realidade de forma responsável.

Ainda segundo esse aspecto, uma outra solicitação, desta vez institucional, foi a da possibilidade de se fazer observações nas salas de aula, ou seja, registrar o transcurso das aulas sem, no entanto, fazer nenhuma interferência direta. Após várias discussões e entendimentos, decidiu-se por realizar essa tarefa nos quartos anos do Ciclo I. Os motivos dessa escolha foram: a questão da conclusão do ciclo de turmas, cuja maioria dos alunos havia estudado na EMEF Vianna Moog desde o primeiro ano, poderia servir de parâmetro dimensional do desenvolvimento do Projeto Político-Pedagógico da escola; além disso, frente a cada vez mais clara repartição da escola entre Ciclos I e II, esse trabalho poderia, de certa forma, beneficiar a interlocução entre os professores dos dois ciclos, no sentido de facilitar a inserção dos alunos no primeiro ano do segundo. Para realizar essa tarefa de observação, foi convidado um estudante de Psicologia cursando o último ano. Ele realizou as observações propostas em todas as classes selecionadas e elaborou relatórios cujos conteúdos foram discutidos, em primeiro lugar, com a professora responsável pela classe e, depois, no grupo que dera seu aval para esse trabalho. Não cabe esmiuçar neste texto quais os apontamentos feitos a partir dessa prática, mas dirigir o foco para as implicações no nível institucional. Em primeiro lugar, vale destacar que não houve unanimidade quanto a essa ação, pois alguns professores mostraram desagrado com relação à realização da observação exclusivamente nos quartos anos. Essa objeção ficou registrada durante todo o processo de discussão feito pelo grupo da manhã que, em suas reuniões, mostrou preferência por um procedimento que fosse adotado em todas as classes, pois, como já explicitado, havia uma pressão na direção de qualquer tipo de "atendimento mais individualizado". O entendimento de que uma ação diferenciada nos quartos anos poderia trazer mais benefícios coletivos do que a "observação" em qualquer outro 
ano não foi suficiente para reverter a posição de alguns membros do grupo que, notadamente, se sentiram desprestigiados com a decisão. A despeito desse embate, a ação foi implementada e, em decorrência dessa, no final do ano letivo de 2002, houve uma reunião específica com os professores dos quartos anos do Ciclo I e dos primeiros anos do Ciclo II, de todas as disciplinas - o que será detalhado mais adiante.

Com o aprofundamento dos estudos teóricos, o grupo pôde esboçar uma idéia de educação inclusiva forjada no coletivo e voltou a pleitear uma interlocução mais significativa com a prática cotidiana, ou seja, como seria a efetivação de tudo isso. Assim, na segunda etapa, iniciada em meados de maio de 2002, cada professor ou grupo de professores foi responsável pela criação e implementação de Projetos de Curta Duração (PCD), cujo mote era a inclusão escolar. A intenção era suscitar a idéia de que a relação entre prática e teoria era de responsabilidade de todos os envolvidos e que não estava "pronta", mas em preparação constante. No grupo da manhã, os assuntos abstraídos do tema foram bastante amplos: concentração, inteligências múltiplas, disciplina, alfabetização, amor e respeito, raciocínio lógico, elaboração de um jornal, recreio. Os pontos de partida foram: o estabelecimento de um foco de pesquisa de acordo com o tema central a ser discutido e desenvolvido com os alunos, significativo para cada turma, cujo conteúdo seria construído coletivamente por meio de várias fontes e que privilegiasse a participação de todos. A regra geral era que fosse feito o registro do processo e que esses projetos tivessem a duração máxima de dois meses, de modo que cada grupo pudesse dispor de tempo para fazer avaliações finais dos trabalhos, as quais seriam centradas em dois pontos principais: qual a relação do projeto com a vida dos alunos e do professor, e quais os conhecimentos adquiridos pelo grupo. Formaram-se trios, duplas e alguns professores trabalharam individualmente.

No grupo da tarde, ficou decidido que seria realizado um único projeto para proporcionar uma aproximação maior entre os docentes - a maioria do Ciclo II e EJA - que tinham poucas oportunidades de trabalharem juntos. $O$ tema escolhido foi o estudo do Estatuto da Criança e do Adolescente - ECA, pela pertinência do assunto em consideração à faixa etária dos alunos. A discussão envolveria a questão dos 
direitos e deveres de cada cidadão e se aliava a outra discussão sobre a qual a escola então se dedicava: a criação do Grêmio Estudantil. Para subsidiar a discussão foi exibido o filme O Futuro do Brasil não Merece Cadeia - Diga não à Redução da Idade Penal, produzido pelo Conselho Regional de Psicologia de São Paulo no ano de 2000. Foram distribuídos também alguns gibis elaborados pelo mesmo órgão e material referente à mesma campanha, cujo público-alvo eram as crianças e os adolescentes, para que os professores pudessem trabalhar com os alunos. Ficou decidido que esse grupo faria um Projeto-Piloto com uma das turmas do período noturno e alguns professores ficaram responsáveis pela organização das primeiras tarefas: a leitura do ECA e a seleção de alguns parágrafos para posterior discussão. A coordenadora teve um papel de destaque nessa questão, pois participou de várias reuniões sobre o tema, sempre trazendo mais material para discussão. Ela mobilizou, inclusive, uma palestra sobre o Estatuto da Criança e do Adolescente proferida pelos Conselheiros Tutelares da região. O filme foi apresentado aos alunos e foi proposto um trabalho sobre os artigos $1^{\circ}$ ao $6^{\circ}$ e do $15^{\circ}$ ao $18^{\circ}$. Houve uma exposição dos trabalhos produzidos e a apresentação de duas peças de teatro feitas também pelos alunos, sob a supervisão dos professores-coordenadores de cada turma e o auxílio da professora de artes: uma sobre preconceito e violência, outra sobre discriminação sexual.

Antes do término do primeiro semestre, foi elaborado um questionário que foi respondido por todos aqueles que tiveram contato com o projeto de inclusão, mesmo tendo participações esporádicas, como no caso dos funcionários. Essas avaliações escritas apontaram como pontos fortes do projeto a flexibilidade e a dinâmica implementada no horário de trabalho coletivo; como pontos fracos, o excesso de leitura e o pouco tempo para o aprofundamento dos conceitos. É interessante notar que o discurso antigo, conhecido, de muita leitura, aparece mesclado com a necessidade de mais aprofundamento dos conceitos, cuja forma seria justamente o trabalho teórico. A dinâmica é elogiada, mas a imposição de leituras, criticada. As discussões no espaço institucional foram destacadas como importantes para a sistematização dos aspectos coletivos considerados como geradores de exclusão escolar: a indisciplina e a não-alfabetização dos alunos nos 
anos mais avançados (terceiros e quartos).

No início do segundo semestre, realizou-se uma reunião específica nos dois grupos a fim de que essas avaliações fossem discutidas. Os participantes, nessa oportunidade, ressaltaram a importância da continuidade da proposta de intervenção. Os PDC continuaram a ser desenvolvidos no grupo da manhã, e, no grupo da tarde, como a maioria dos professores foi transferida no segundo semestre para outras escolas, houve a necessidade da (re)leitura dos textos sobre o tema inclusão. No outro grupo, foi introduzido o tema indisciplina, proposto nas avaliações como parte da discussão sobre inclusão. Os participantes discutiram alguns aspectos relacionados a esse assunto ${ }^{40}$, como a necessidade de pactos coletivos, multilaterais, claros, estabelecidos por meio de diálogos mediados pelo saber, que é o objeto institucional da escola. Apesar de mostrarem entendimento sobre os textos, os apontamentos realizados durante as discussões eram bastante diversos sobre o assunto e em relação ao papel da escola. No fluxo da "indisciplina", vários outros conceitos foram retomados, tais como inclusão, avaliação, planejamentos, ciclos, o interesse pelo saber, a questão dos vínculos familiares, a busca de caminhos etc.

Em setembro, os dois grupos passaram a ler os mesmos textos e a partilhar dos mesmos disparadores. Como forma de marcar esse momento de integração, foi utilizado o laboratório de informática e apresentado um resumo dos textos lidos em slides no programa power-point, com cada dupla em um computador acompanhando a exposição e colocando suas questões, finalizando, momentaneamente, as discussões específicas sobre esse tema. No grupo da manhã, os PCD foram finalizados e a discussão migrou para o planejamento geral da EMEF, com vistas a ampliar a reflexão sobre os "projetinhos" - como eram chamados os PCD pelos participantes. A experiência intencional do planejamento, implementação e avaliação nos Projetos de Curto Prazo levantou questões e propostas que possibilitaram aos protagonistas iniciar a discussão do Projeto Político-Pedagógico da escola. A intenção era de não se contentar com o tempo oficialmente dado para esta tarefa, mas

40 Os textos utilizados foram de Júlio Groppa AQUINO, "A desordem na relação professor-aluno: indisciplina, moralidade e conhecimento". In J. G. AQUINO, Do cotidiano escolar: ensaio sobre a ética e seus avessos, 2000, pp. 81-100 e de Maria Tereza ESTRELA, Relação pedagógica, disciplina e indisciplina, 1992. 
começar sua sistematização a partir de outubro, início do último trimestre, aproveitando as conversas nos horários de trabalho coletivo.

A partir de textos distribuídos sobre o assunto pelo poder público municipal, representado pelo Núcleo de Ação Educativa 12, foi traçado um paralelo sobre a inclusão e o planejamento escolar. O diagnóstico, os objetivos, as ações e a avaliação - em outras palavras, como a escola está, quais são as mudanças necessárias e como implementá-las - devem ser fruto de embate para depois compor o Plano Escolar. Dessa forma, este tem sempre um caráter provisório, resultado de um movimento permanente de planejamento, cuja proposta reflete os pensamentos, ações e reflexões dos participantes acerca da realidade escolar. $\mathrm{Na}$ EMEF Vianna Moog, o princípio da inclusão, tomado como perspectiva norteadora do planejamento, demandava a implicação e responsabilidade de todos num projeto para a viabilização de uma escola que caminhasse na busca de mecanismos que rompessem com os processos de exclusão já diagnosticados. O acordo coletivo de não querer mais "fabricar" alunos analfabetos e justificar a exclusão de outros por motivos disciplinares era fato, mas como atuar de forma a realizar essa tarefa foi a grande dificuldade apontada. Para iniciar a construção de uma proposta de consenso no que se refere às questões básicas como, por exemplo, quais são os requisitos para um aluno ser considerado apto para cursar esse ou aquele ano letivo, foi elaborado um levantamento de qual expectativa para cada ano, para aprimorar-se o diagnóstico. Para o Ciclo II e EJA, a estratégia foi consultar os alunos, por meio de questionário, sobre quais são suas maiores dificuldades, as matérias mais interessantes, e o que cada um acredita que a escola pode fazer para ajudá-lo a ter um aproveitamento pedagógico mais interessante. Os alunos afirmaram que tanto os projetos especiais, com a discussão de temas transversais, como o atendimento individual feito pelo professor, seriam os meios mais eficazes de apoio pedagógico extra-classe. Mas fizeram também colocações a respeito da falta de professores. Essas respostas foram analisadas, devolvidas para cada turma em forma de porcentagem e usadas como subsídios nas discussões sobre o planejamento para 2003. No grupo I, foram feitos levantamentos individuais sobre quais os requisitos básicos para cada ano letivo. A preocupação dos professores dos três ciclos era a 
mesma, qual seja, que a escola pudesse cumprir sua função social melhor do que naquele momento, no sentido de se transformar num espaço que possibilitasse a participação para todos e que inspirasse respeito da comunidade.

Após os levantamentos, algumas idéias de projetos de apoio surgiram durante as reuniões de novembro de 2002, enfocando a idéia de inclusão "pedagógica": o de Alfabetização voltado para o aluno que não escreve e não lê; o de Alfabetização II para o que escreve e lê, mas não produz texto; o de Tutoria, para alunos que foram aprovados para o Ciclo II, mas que precisam de um apoio diferenciado.

Na reunião já mencionada entre os professores dos quartos anos do Ciclo I e dos primeiros anos do Ciclo II, foram estabelecidas algumas diretrizes: que a promoção ou a retenção de um aluno do último ano do ciclo é de responsabilidade da escola como um todo; que há a necessidade de se diminuir o distanciamento entre a realidade e o que se espera dos alunos; que há também a urgência em se minimizar a ruptura que há nessa passagem. As professoras chegaram a um consenso sobre quais os critérios para que um aluno tenha conceito $P, S$ ou N/S (Plenamente satisfatório, Satisfatório e Não/Satisfatório) no quarto ano do Ciclo I. Houve uma reflexão a respeito da forma como está estruturado o sistema e suas implicações para o último ano do ciclo, quando os problemas de aprendizagem que vêm se acumulando ao longo do processo desembocam. O consenso geral foi o de que uma medida a ser tomada para os alunos que estão principalmente dos terceiros anos em diante é o desenvolvimento de projetos pedagógicos paralelos na e pela escola, no sentido de amadurecer habilidades apontadas como imprescindíveis para a inserção real num processo pedagógico considerado interessante. Essa reunião representou um marco na tentativa de superação da ruptura entre os ciclos e na busca de outras soluções para os problemas que se apresentam.

Assim, foi realizada uma nova avaliação no final do segundo semestre de 2002 sobre o projeto de inclusão. Foi elaborado um questionário que procurou delinear a relação entre os participantes com o projeto ao longo do ano letivo. Foram recolhidas 25 respostas, a partir das quais foram selecionados alguns itens no intuito de ilustrar o procedimento. Para apresentação dos dados optou-se por agrupá-los, 
não sendo anexado os questionários respondidos, tendo em vista que os mesmos encontram-se identificados.

As respostas estão apresentadas em forma de tabela para tornar possível a visualização do relacionamento do grupo com a proposta. Essa preocupação em termos de avaliação procurou ser coerente com o trabalho que partiu de um delineamento de ações e experiências que compunham a prática efetiva e as teorias sobre o tema e que, por intermédio de debate, buscou novas formas de se pensamento e atuação coletiva.

Todas as respostas relativas aos pontos fortes do trabalho (ver tabela A) refletiram, de alguma forma, o afinamento dos participantes com a meta de discussão da e na escola de seu Projeto Político-Pedagógico como estratégia para construir uma unicidade entre planejamento e ação. Com relação aos pontos fracos (tabela B), além de $24 \%$ não ter apontado nenhum, 36\% apontaram questões de infra-estrutura, enquanto o restante das respostas (40\%) podem ser entendidas como dificuldades no processo.

Tabela A - Pontos Fortes do Projeto

\begin{tabular}{|l|c|}
\hline \multicolumn{1}{|c|}{ Pontos fortes } & Número de resposta \\
\hline O envolvimento da escola com o Projeto Político Pedagógico & 6 \\
\hline $\begin{array}{l}\text { A experiência de lidar com as diferenças com coragem para } \\
\text { estabelecer conflitos de idéias e buscar novas formas de abrir } \\
\text { caminhos coletivamente }\end{array}$ & 5 \\
\hline A aproximação dos ciclos & 4 \\
\hline A ampliação do significado de inclusão e de outros conceitos & 3 \\
\hline A relação estreita entre teoria e prática & 2 \\
\hline A flexibilidade do projeto & 2 \\
\hline A troca de experiências & 1 \\
\hline A busca da competência da escola como formadora & 1 \\
\hline A pertinência do tema com a realidade escolar & 1 \\
\hline
\end{tabular}

Tabela B - Pontos fracos do Projeto 


\begin{tabular}{|l|c|}
\hline \multicolumn{1}{|c|}{ Pontos fracos } & Número de respostas \\
\hline Não teve & 06 \\
\hline O tempo curto & 04 \\
\hline $\begin{array}{l}\text { A falta de infraestrutura da região e da escola trazendo } \\
\text { dificuldades para implantar o PPP }\end{array}$ & 02 \\
\hline Não houve a presença de todos os professores & 02 \\
\hline A dificuldade de aceitação pelo grupo das leituras & 02 \\
\hline $\begin{array}{l}\text { O grupo compreendeu as questões individualmente, por } \\
\text { vezes monopolizando a discussão }\end{array}$ & 03 \\
\hline Rotatividade dos professores & 01 \\
\hline $\begin{array}{l}\text { Falta de atendimento individual e não houve solução para os } \\
\text { alunos excluídos }\end{array}$ & 01 \\
\hline Não houve entrosamento entre todos os professores & 01 \\
\hline Falta de definição mais clara do que é inclusão & 01 \\
\hline $\begin{array}{l}\text { Falta de momentos de troca de experiências entre os } \\
\text { professores }\end{array}$ & 01 \\
\hline Teoria distante da prática & 01 \\
\hline
\end{tabular}

Quanto à participação, embora vários termos tenham sido utilizados, por se tratar de pergunta aberta, aproximadamente $80 \%$ das respostas atribuíram adjetivos que podem ser considerados positivos com relação ao grupo (tabela C), e 60\% com relação à sua própria (tabela $\mathrm{D}$ ). Quanto aos textos, motivo de descontentamento inicial, $80 \%$ avaliaram as leituras de forma positiva (conforme tabela E).

Tabela C - Quanto à Participação dos Colegas

\begin{tabular}{|l|c|}
\hline \multicolumn{1}{|c|}{ Quanto à participação dos colegas: } & Número de respostas \\
\hline Boa & 7 \\
\hline Positiva & 6 \\
\hline Produtiva ou Engajada & 3 \\
\hline Não avaliaram & 2 \\
\hline Pobre & 2 \\
\hline Razoável & 2 \\
\hline Não leram os textos previamente & 1 \\
\hline Satisfatória & 1 \\
\hline Melhorando durante o processo & 1 \\
\hline
\end{tabular}

Tabela D - Quanto à própria participação 


\begin{tabular}{|l|c|}
\hline \multicolumn{1}{|c|}{ Quanto à própria participação } & Número de respostas \\
\hline Positiva & 7 \\
\hline Poderia participar mais & 4 \\
\hline Questionadora & 2 \\
\hline Pertinente & 2 \\
\hline Precária & 2 \\
\hline Melhorando durante o processo & 2 \\
\hline Satisfatória & 1 \\
\hline Tímida & 1 \\
\hline Não avaliaram & 1 \\
\hline Poderia ter falado menos & 1 \\
\hline Ouvinte & 1 \\
\hline Razoável & 1 \\
\hline
\end{tabular}

Tabela E - Quanto aos textos utilizados

\begin{tabular}{|l|c|}
\hline \multicolumn{1}{|c|}{ Quanto aos textos utilizados } & Número de respostas \\
\hline Bons & 7 \\
\hline Muito bons & 5 \\
\hline Pertinentes & 4 \\
\hline Importantes e Ricos & 4 \\
\hline Descreveram os textos ou não avaliaram & 4 \\
\hline Poucos & 1 \\
\hline
\end{tabular}

Para finalizar este capítulo, foram agrupadas as formulações elaboradas pelos participantes (dois participantes não fizeram) sobre o conceito de educação inclusiva. A transcrição desses registros foi realizada com o objetivo de dar voz aos agentes que são interlocutores e beneficiários das políticas públicas educacionais no que diz respeito à formação continuada, buscando envolver todos na construção de conhecimento coletivo, um dos pressupostos centrais da perspectiva em questão.

- Oportunidade de acesso contínuo à educação para o domínio da leitura e escrita no sentido da inclusão social, da formação do cidadão. Diante das dificuldades sociais, a escola serve como espaço de socialização, ainda que não atinja suas funções da maneira esperada. (sete respostas)

- Acolher todos para uma convivência mais enriquecedora com a melhora da 
qualidade de vida de todos no coletivo, com respeito às diferenças. Dar chance de expressão sem rótulos prévios. (cinco respostas)

- Dar espaço não só para os deficientes, mas para as pessoas com pouco poder aquisitivo e analfabetos que não se sentem parte do grupo, através de situações escolares se sintam parte do processo dentro de seu ritmo e tempo. (cinco respostas)

- A arte de olhar para o outro e permitir que ele ocupe seu espaço. É a adoção de uma postura levando em consideração que todos somos diferentes, mas que podemos nos realizar nos mesmos espaços, de formas diversas. (quatro respostas)

- Uma idéia viva e forte que leva à superação de barreiras e uma noção de justiça e dignidade, que nunca acaba. (duas respostas)

Depois da devolutiva dessa avaliação, ainda no ano de 2002, foi deliberado que a escola pleitearia junto ao Núcleo de Ação Educativa mais um ano para a continuidade do processo, o que foi conseguido em 2003. Outro aspecto interessante é que tanto nos Pólos como no próprio NAE 12, a EMEF Vianna Moog ficou conhecida por suas incursões em busca do aprimoramento da qualidade de ensino para sua comunidade. Algumas das ações, como o projeto de inclusão e o curso de LIBRAS, foram encampadas pelo sistema e oferecidas, pelo NAE 12, a todas as escolas do Núcleo. 


\section{CONSIDERAÇÕES FINAIS}

A proposta deste estudo foi, a partir da discussão do tema educação inclusiva, possibilitar uma trajetória conjunta segundo a qual pesquisadora e grupo de educadores trabalhassem em prol da reelaboração do conhecimento acumulado sobre a realidade em que estão inseridos, com o intuito de construir soluções para as situações apontadas como indesejadas. A intervenção, como construção in loco, paulatina e processual de um espaço democrático, tendo a ambiência inclusiva como perspectiva, buscou delinear uma concepção de inclusão que ultrapassasse o âmbito das deficiências.

As prioridades em políticas públicas ${ }^{1}$ são oriundas da sociedade e podem ser contempladas pela agenda governamental quando grupos se organizam em torno dela, como é o caso da educação inclusiva como convergência de pleitos da educação especial e da comum. $\mathrm{O}$ objeto educacional entendido como investimento social e político tem sua definição afirmada na perspectiva do direito social que deve ser assegurado e defendido, diferenciando-se da noção de um privilégio ou de um serviço, dado que não se define com vistas a dinamizar a acumulação e a reprodução do capital.

Para ser implementada, a educação carece da atuação cotidiana dos agentes sociais, imprimindo uma perspectiva dinâmica de acordo com a avaliação ${ }^{2}$ passa a ser sempre diagnóstica. Dessa forma, avaliar o ponto onde se encontra determinada

1 Cf. Isaura BELLONI; Heitor de MAGALHÃES e Luzia Costa de SOUSA, Metodologia de avaliação em políticas públicas, 2001, p. 44. Apud Rosângela Gavioli PRIETO; Liliane GARCEZ et al., Educação inclusiva: o desafio de ampliar o atendimento de alunos com qualidade e a formação docente. Pesquisa sobre políticas públicas em Educação, aprovado pela Área de Políticas Públicas da FAPESP/2002. "[...] política pública é a ação intencional do Estado junto à sociedade. Assim, por estar voltada para a sociedade e envolver recursos sociais, toda política pública deve ser sistematicamente avaliada do ponto de vista de sua relevância e adequação às necessidades sociais."

2 Cf. Isaura BELLONI; Heitor de MAGALHÃES e Luzia Costa de SOUSA, op. cit. , p. 44. Apud Rosângela Gavioli PRIETO; Liliane GARCEZ et al., op. cit. "Os principais objetivos que justificam o desenvolvimento de estudos que avaliam políticas públicas são 'conhecer seus fatores positivos, apontar seus equívocos e insuficiências, com a finalidade de buscar seu aperfeiçoamento ou reformulação'; o outro é 'oferecer subsídio para a tomada de decisão', que 'refere-se tanto à continuidade da política examinada, quanto a ajustes ou reformulações de suas ações, em face dos objetivos da própria política e/ou os dos setores atingidos." 
proposta é, ao mesmo tempo, diagnosticar o momento seguinte.

Se assim o for, alguns paradigmas pedagógicos que eram eficazes em momentos anteriores por vezes não mais respondem tão efetivamente como no passado recente. O trabalho volta-se não para explicar quais são os possíveis culpados pelo insucesso da escola hoje, mas para a busca de caminhos que apontem propostas pedagógicas e políticas de formação num embate social inovador. A qualidade social da educação está mesclada à idéia de quantidade. A primeira passa pela segunda, pois na medida em que existem condições cada vez mais ampliadas de acesso e permanência diminuindo a evasão e a repetência, há um aumento da qualidade social da educação. Sustentar, assim, que o aumento da quantidade de cidadãos na escola pública leva a uma queda na qualidade é uma afirmação parcial e, por vezes, perversa.

Diferente da visão pragmática de condicionar a qualidade educacional ao sucesso no mercado de trabalho, o fortalecimento da função social que legitima a existência da escola como instituição, privilegia o acesso ao conhecimento universal acumulado e sua apropriação pelos sujeitos. Essa formação relacionada tanto com a existência social como com a individual possibilita a compreensão da própria realidade em que se insere, de modo a transformar conhecimentos científicos em ferramentas de ação. $O$ acesso de todos a quaisquer formas de conhecimento pode ser base para a reflexão dos educadores sobre o sentido social concreto do que fazem, na direção dos interesses da maioria da população. Assim, a formação para a cidadania, para além da conveniência de um discurso "politicamente correto", está imbricada na formação de educadores. Uma das maneiras de ela se objetivar é de forma continuada no interior das próprias escolas nas quais os envolvidos são coresponsáveis por sua elaboração, execução e avaliação. No cotidiano das escolas, um desses instrumentos de trabalho é o projeto político-pedagógico, que articula propostas de todos os segmentos da comunidade escolar e auxilia no estabelecimento e no desenvolvimento de canais e de estratégias, no sentido de aprimorar a qualidade social no trabalho educativo.

A formação deve ser entendida, segundo Marilena Chauí, como 
introduzir alguém ao passado de sua cultura, é despertar alguém para as questões que esse passado engendra para o presente [...] e este é apreendido como aquilo que exige de nós o trabalho da interrogação, da reflexão e da crítica, de tal maneira que nos tornamos capazes de elevar ao plano do conceito o que foi experimentado como questão, pergunta, problema, dificuldade ${ }^{3}$.

A formação continuada é, portanto, exercício de compreensão dos conteúdos e também das contingências sociais e políticas que constituem o trabalho. A formulação de alternativas que permitam romper com a exclusão, o descompromisso social, a solidão e o preconceito pode ser efetivada pela observação e experimentação de ações historicamente contextualizadas para a compreensão de suas causas e conseqüências.

Dispor a dialética da inclusão/exclusão como forma de relação social constitutiva do capitalismo neoliberal e tomar a educação como um direito de todos os cidadãos a ser conquistado estabelecem um compromisso ético-político comum, tanto para estender a possibilidade de atendimento educacional quanto para minimizar os processos de fragmentação deste objeto. A universidade pode contribuir para estimular espaços em que os conhecimentos específicos construídos nos diversos loci possam dialogar, implicando os outros níveis de ensino, e estimulando o aprofundamento de questões atuais relevantes mediante condições para leitura e pesquisa, isto é, para reflexão e crítica, e não para estimular a superficialidade e a hierarquização de saberes.

É na escola que se tem a possibilidade de assegurar, simultaneamente, a universalidade dos conhecimentos e as especificidades locais, promover o diálogo entre o conhecimento de questões clássicas da área, dos problemas contemporâneos e das pesquisas existentes no país e no mundo sobre os assuntos mais relevantes. Para isso, obviamente, são necessárias condições materiais de trabalho como bibliotecas, salários que permitam ao professor dedicar-se à docência e à pesquisa num processo de formação e de atualização dos conhecimentos e das técnicas pedagógicas, e, além disso, espaços onde possa haver o intercâmbio dos saberes

3 Marilena CHAUÍ, op. cit., 2003. 
dos educadores e entre as instituições de modo a familiarizá-lo com as diferenças e especificidades.

Esse relato, à guisa de apontar as características do trabalho docente na atualidade, pretendeu ilustrar as condições de execução de uma proposta extensiva de educação e suas repercussões entre os envolvidos, tendo como base a idéia de vivenciar um caminho trabalhado coletiva e continuamente, como algo capaz de provocar novas negociações entre os diferentes segmentos, impulsionando transformações a partir da revisão sistemática e intencional das concepções e práticas em curso no cotidiano escolar. A responsabilidade formativa levou em consideração o conhecimento produzido na escola, resultado do acúmulo de experiências e pilar para sua reorganização e recriação, no intuito de responder às questões cotidianas mais prementes.

O descompasso entre as políticas públicas e sua tradução no cotidiano das escolas apontou não para deficiências a serem sanadas, ou diferenças a serem homogeneizadas, tampouco para a necessidade de se criar um novo método pedagógico, mas para os embates que ainda não foram feitos, para as leis que ainda não se efetivaram, para as brechas nas quais se pode atuar. A formação continuada articulada aos saberes dos professores, tomando as escolas como lugares de referência e alicerçados numa reflexão na prática sobre a prática por meio de dinâmicas de investigação-ação, não se relaciona a um treinamento ou a uma capacitação no sentido de execução de tarefas ou receitas educacionais - como se fossem possíveis "mudanças de olhares estereotipadas" - mas a um processo contínuo e coletivo, no sentido da potencialização das ações dos protagonistas.

A questão da formação dos professores e suas formas de implementação encontram-se dentre as preocupações centrais para a efetivação da perspectiva inclusiva na educação. Por vezes, o que se afirma é que o olhar do professor deve ser mudado para que a educação seja efetivamente de qualidade para todos. Esse tipo de discurso sobre os professores tem caracterizado boa parte das ações, mesmo daqueles que se colocam na perspectiva da inclusão, optando por uma homogeneização do ambiente para a aplicação de receitas globalizantes. Não se leva em consideração o que o professor conhece; pouco se sabe efetivamente sobre qual 
a dinâmica do contexto do qual se decide produzir conhecimento. O núcleo da ação é a "capacitação" ou "reciclagem" dos educadores para atender às necessidades do modelo proposto. A qualidade escolar passa a ser medida pela capacidade de reprodução de determinado procedimento. Reproduz-se a forma de transmissão do conhecimento para os professores, ao mesmo tempo em que se exige dos mesmos uma nova forma de atuação com os alunos, o que encerra contradições, entre o discurso e a forma de intervir junto ao docente.

Diante dessa leitura, esse trabalho não pretendeu ser caracterizado como uma pesquisa cujo objeto eram os professores e sua atuação na perspectiva da "educação inclusiva", mas como um trabalho de reflexão coletiva como estratégia para uma atuação que incluísse a todos no processo pedagógico. Menos para constatar, mais para questionar e construir. Assim, do modo como o projeto foi concebido e implementado, as dificuldades e os êxitos foram formulados coletivamente pela escola, por seus protagonistas e pela pesquisadora. Foram construções coletivas que apareceram amalgamadas e que contemplam, em seu conjunto, todos os participantes, esboçando um quadro de preocupações comuns.

Todo o sentido da proposta foi o de buscar do aprendizado de novos repertórios de ação, posteriormente transferíveis para outros espaços, ou não, com o objetivo de ampliar os recursos de sociabilidade em direção a valores de respeito às diferenças. A normalização de condutas, postura antagônica à perspectiva da inclusão, por vezes subjazia à demanda dos protagonistas escolares, ou seja, os próprios professores clamavam, assim, por receitas padronizadas.

A pressa em obter aplicações práticas tem contribuído para desvalorizar, em parte, a pesquisa e o estudo mais aprofundado das questões educacionais. 0 descrédito desses dois instrumentos, que são constitutivos do próprio desenvolvimento da tarefa docente, determina aos professores o lugar subumano de "implementadores" e de "fazedores" de projetos estereotipados e messiânicos, propostos de fora para dentro e de cima para baixo. Este mecanismo cria, por vezes, uma certa expectativa que um especialista técnico virá transmitir as novas regras para o trabalho pedagógico, como no caso do burocrata que fica esperando as novas 
diretrizes em tempos de paz ${ }^{4}$, ou de democracia, ou de cidadania, ou de diversidade, sem que este precise se aproximar do cotidiano da instituição e sem que aqueles precisem "pensar" sobre o que estão fazendo, numa desresponsabilidade paulatina do trabalho docente. Assim, há uma demanda de que a resolução de problemas pontuais das salas de aula passe pela aquisição de conhecimentos bem específicos e construídos sem a implicação dos protagonistas escolares.

Durante o desenrolar da pesquisa aqui relatada, a despeito do interesse e do compromisso apresentados pelos professores para o desenvolvimento do trabalho, essas questões apresentavam-se sob a forma de uma certa descrença generalizada sobre as possibilidades de transformação do cotidiano escolar, sobre a possibilidade de se realizar um trabalho coletivo na escola e sobre a própria perspectiva que 0 professor tem de sua atividade. E, embora esses movimentos estivessem ocorrendo, a falta de respostas imediatas aos problemas que se apresentavam mobilizava 0 grupo em torno da necessidade de uma solução "mágica", quase divina. Em vários momentos, essa idéia aparecia revestida das mais diversas formas.

O não atendimento dessa demanda a partir da compreensão de que a formação, na perspectiva da inclusão, não se encaixa nos moldes de uma especialização ou de atualização de conhecimentos pedagógicos, fortaleceu a idéia de que não há possibilidade de uma preparação pré-moldada, mas apenas pontos de partida possíveis que pressupõem o compartilhamento constante de idéias, entendimentos e ações. Não há como construir partindo de algo externo, apriorístico, mas a partir de experiências, teorias e práticas pedagógicas, pois o objetivo não é o de fomentar a reprodução, mas o surgimento de questões. O foco específico da pesquisa e os temas mais amplos da escola levantados nesse período foram se aproximando, privilegiando o processo educativo, que é, em parte, o que tem sido solicitado ao professor para que este faça em sala de aula. Dedicar-se a um tema

\footnotetext{
4 Bosco BRASIL, Novas diretrizes em tempos de paz. Direção: Ariela Goldman. Parafraseio o nome dessa peça de teatro que versa sobre um funcionário público que ainda não recebeu quais as novas instruções com relação a entrada de estrangeiros no Brasil, a despeito do término da Segunda Grande Guerra na Europa, e fica entre agir de acordo com as diretrizes relacionadas ao período de guerra ou implicar-se na tomada de uma decisão que ainda não está normatizada frente a um pedido de um estrangeiro para entrar no país.
} 
que faça sentido para sair das respostas prontas de senso comum, à luz do conhecimento acumulado, tanto na escola, como na universidade e nos fóruns de debate, ao mesmo tempo em que se dava uma resposta negativa à demanda inicial, estimulou os participantes a pensarem em propostas que fizessem frente aos problemas que levantavam, como forma de procurar superá-los.

A pesquisa-ação desenvolvida procurou reconhecer e valorizar as diferenças por meio de enfoques metodológicos e estratégias pedagógicas que possibilitaram a construção coletiva do conhecimento, com isto, estava posta a intenção de valorizar o educador como agente institucional, fazendo do projeto um dos caminhos possíveis. Partir do Projeto Político-Pedagógico e fazer uma leitura coletiva contribuiu para que cada vez mais vozes fossem contempladas, no sentido de tornar mais perceptíveis a todos as características significativas da escola, tanto as que eram passíveis de manutenção quanto as de transformação. Essas informações, analisadas no coletivo, permitiram uma definição mais clara dos aspectos que careciam de mais cuidado. A história da instituição não poderia ser lida nem destrinchada sob a forma de aspectos positivos e deficiências, mas de características e possibilidades, abrindo caminhos ao surgimento de estratégias coletivas de trabalho.

A execução dessa tarefa implicou a necessidade de alargamento da integração e da comunicação entre professores e equipe de direção, e de uma definição mais clara dos papéis institucionais, pois as "indicações" vindas do poder público podem e devem ser discutidas pelo coletivo para que este possa contribuir para seu aperfeiçoamento a partir dos problemas vividos no trabalho cotidiano na escola, promovendo um fortalecimento do grupo e a preservação da autonomia da instituição escolar e dos seus agentes. O exercício do debate, entendido como confronto de posições e não de pessoas, não se dá de forma espontânea; é uma construção que só pode ser realizada pelos participantes nos espaços coletivos de trabalho. As discussões das regras de convivência, as tomadas de decisões e a realização de atividades que articulem várias disciplinas, aulas e professores foram um movimento importante para a realização de bons encontros.

As atividades, sempre planejadas com linguagem e recursos que trazem conhecimentos a partir do já posto, possibilitaram o envolvimento de mais 
participantes para trabalho do conhecimento mediante abordagens ampliadas do conteúdo, visando a mudar a relação de todos com o saber, e ampliando as possibilidades de cooperação e convívio em grupo, em direção aos valores de tolerância e respeito.

A vivência como integrante "estrangeiro" de um grupo de formação no horário de trabalho coletivo assemelhou-se bastante muito à participação em fóruns. As especificidades de grupos que alteram sua constituição de forma intensa durante determinado processo, como é o caso de ambos, possibilitou a leitura do rodízio de professores e da diversidade de momentos e de conhecimentos como uma característica atual da escola pública e imprimiu na dedicação a uma tarefa conjunta a possibilidade de resistência coletiva à implantação das políticas sociais neoliberais. O objetivo central, portanto, foi a construção, a implementação e a avaliação do Projeto Político-Pedagógico, imprimindo uma vivacidade a um documento que, por vezes, aparece como obrigação meramente burocrática. Algumas das propostas levadas a cabo pela escola no ano de 2002 foram transformadas em projetos encampados pelo sistema, como já mencionado, inclusive o "projeto de inclusão".

Para essa pesquisa-intervenção ser realizada como ação ético-política, valores como a cooperação e a solidariedade não poderiam ser entendidos como idealistas, tampouco mecanicistas, mas passíveis de serem gestados no cotidiano escolar. Nem o intangível, nem o discurso vazio, nem o contentamento com o que está posto, mas a busca pela confrontação cotidiana de novas diretrizes para a educação no sentido da renovação da capacidade de projetar.

O sonho de um mundo melhor nasce das entranhas de seu contrário. [...] Por isso, aceitar o sonho de um mundo melhor e a ele aderir é aceitar entrar no processo de criá-lo. Processo de luta profundamente ancorado na ética.[...] Luta contra o desrespeito à coisa pública. [...] E tudo isso, com momentos, apenas, de desencanto, mas sem jamais perder a esperança. Não importa em que sociedade estejamos e a que sociedade pertençamos, urge lutar com esperança e denodo ${ }^{5}$.

5 Paulo FREIRE, op. cit. , 2000, pp. 133-134. 
BIBLIOGRAFIA

OBRAS DE REFERÊNCIA

ABBAGANANO, N. Dicionário de filosofia. 2a ed., São Paulo: Mestre Jou, 1982.

BRUGGER, W. Dicionário de filosofia. 2a ed., São Paulo: Herder, 1969.

CONSTITUIÇÃO DA REPÚBLICA DOS ESTADOS UNIDOS DO BRASIL. Constituição Federal. Rio de Janeiro, 1934.

CONSTITUIÇÃO DA REPÚBLICA FEDERATIVA DO BRASIL. Constituição Federal. Brasília, 1988.

DECLARAÇÃO DE COCHABAMBA. Cochabamba, 2001. www.unesco.org.br.

DECLARAÇÃO DE DAKAR. Marco de Ação de Dakar. Dakar, 2000. www.unesco.org.br.

DECLARAÇÃO DE NOVA DELHI. Nova Delhi, 1993. www.unesco.org.br.

DECLARAÇÃO DE SALAMANCA - de princípios, política e prática para as necessidades educativas especiais. Salamanca: 1994. www.cedipod.org.br/salamanc.htm.

DECLARAÇÃO MUNDIAL SOBRE EDUCAÇÃO PARA TODOS. New York: WCEFA, abril 1990. www.unesco.org.br.

DECRETO 33.991/94 Regimento comum das escolas municipais. São Paulo, 1994.

ECO, U. Como se faz uma tese. São Paulo: Perspectiva, 1985.

FERREIRA, A. B. H. Novo Aurélio Século XXI: o dicionário da língua portuguesa. $3^{a}$ ed., Rio de Janeiro: Nova Fronteira, 1999.

LALANDE, A. Vocábulo técnico e crítico de filosofia. Porto: Rês, 1960.

LEI ORGÂNICA DO MUNICÍPIO DE SÃO PAULO. Constituição Municipal. São Paulo, 1990.

LEI 4.024/61. Lei de Diretrizes e Bases da Educação Nacional (LDB). Brasília, 1961. 
LEI 9.394/96. Lei de Diretrizes e Bases da Educação Nacional (LDB). Brasília, 1996.

LEI 8.069/90. Estatuto da Criança e do Adolescente (ECA). Brasília, 1990.

LEI 10.172/01. Plano Nacional de Educação. Brasília, 2001.

LEI 11.229/92. Estatuto do Magistério Público do Município de São Paulo. São Paulo/SP, 1992.

LEI 11.434/93. Reenquadra cargos e funções, estabelecidos na Lei $n$. 10.430/88 e na Lei 11.229/92. Na área do Ensino Municipal cria novas Escalas de Padrões de vencimentos e institui planos de carreira. São Paulo/SP, 1993.

ORGANIZAÇÃO DAS NAÇÕES UNIDAS (ONU) Declaração Universal dos Direitos Humanos. 1948.

PLÁCIDO E SILVA, O. J. Vocabulário Jurídico. Rio de Janeiro: Forense, 1967.

PORTARIA INTERSECRETARIAL 6/02. Criação das subprefeituras no Município de São Paulo. São Paulo, 2002.

PORTARIA 2.083/93. Secretaria Municipal de Educação. Projetos Estratégicos de Ação. São Paulo, 1993.

PORTARIA 3.826/97. Secretaria Municipal de Educação. Projetos Especiais de Ação. São Paulo, 1997.

RESOLUÇÃO CNE/CEB n. 02/01. Diretrizes Nacionais para educação especial na educação básica. Brasília, 2001.

SEVERINO, A. J. Metodologia do trabalho científico. $22^{\mathrm{a}}$ ed. rev. e ampl., São Paulo: Cortez, 2002. 
OBRAS GERAIS

ALCUDIA, R. et. al. Atenção à diversidade. Porto Alegre: Artmed, 2002.

ANDRÉ, M. "A pedagogia das diferenças". In ANDRÉ, M. (org.). Pedagogia das diferenças na sala de aula. Campinas: Papirus, 1996.

AQUINO, J. G. Do cotidiano escolar: ensaios sobre a ética e seus avessos. São Paulo: Summus, 2000.

Moderna, 2002.

Diálogos com educadores: o cotidiano escolar interrogado. São Paulo:

Indisciplina: o contraponto das escolas democráticas. São Paulo:

Moderna, 2003.

ARANHA, M. S. F. "Integração social do deficiente: análise conceitual e metodológica". Temas em Psicologia, n. 2. Ribeirão Preto: Sociedade Brasileira de Psicologia, 1995.

deficiência". Revista do Ministério Público do Trabalho, n. 21. Brasília: LTR, 2001.

A inclusão social da criança especial. São Paulo: Roca (no prelo) apud CORRER, R. Deficiência e inclusão social: construindo uma nova comunidade. Bauru: Edusc, 2003.

ARENDT, H. Entre o passado e $o$ futuro. $5^{a}$ ed. $1^{a}$ reimp., São Paulo: Perspectiva, 2001.

ARROYO, M. "Educação em tempos de exclusão". In FRIGOTTO, G. e GENTITLI, P. (orgs.). A cidadania negada: políticas de exclusão na educação. São Paulo: Cortez, 2001.

ASSOCIAÇÃO DOS DOCENTES DA UNIVERSIDADE DE SÃO PAULO. Como e por quê as fundações privadas "de apoio" estão destruindo o caráter público e gratuito da USP. São Paulo: Adusp, 2004.

O controle ideológico na USP (1964-1978). São Paulo: Adusp, 2004.

AZANHA, J. M. P. "Política e planos de educação no Brasil: alguns pontos para reflexão". Cadernos de Pesquisa, n. 85. São Paulo, 1993. 
BAPTISTA, L. A. A cidade dos sábios: reflexões sobre a dinâmica social nas grandes cidades. São Paulo: Summus, 1999.

BELLONI, I.; MAGALHÃES, H. e SOUSA, L. C. Metodologia de avaliação em políticas públicas. $2^{a}$ ed., São Paulo: Cortez, 2001.

BEISIEGEL, C. R. Estado e educação popular: um estudo sobre a educação de adultos. São Paulo: Pioneira, 1974.

BLACKBURN, R. Depois da queda: o fracasso do comunismo e o futuro do socialismo. $2^{\text {a }}$ ed., Rio de Janeiro: Paz e Terra, 1993.

BOBBIO, N. A era dos direitos. Rio de Janeiro: Campus, 1992.

. O futuro da democracia. 9a ed., Rio de Janeiro: Paz e Terra, 2000.

BOGDAN, Robert C. e BIKLEN, S. Investigação qualitativa em educação: uma introdução a teoria e aos métodos. Porto: Porto Editora, 1994.

BOURDIEU, P. Escritos de educação. Petrópolis: Vozes, 2001.

. Contrafogos: táticas para enfrentar a invasão neoliberal. Rio de Janeiro: Jorge Zahar, 1998.

. O poder simbólico. Lisboa: Difel, 1989.

Razões Práticas: sobre a teoria da ação. Campinas: Papirus, 1997.

BRANDÃO, C. R. (org.). Pesquisa participante. 5a ed., São Paulo: Brasiliense, 1985.

. "Pesquisar-participar". In BRANDÃO, C. R. (org.). Pesquisa participante. 5a ed., São Paulo: Brasiliense, 1985.

(org.). Repensando a pesquisa participante. $3^{a}$ ed. $1^{a}$ reimp., São Paulo: Brasiliense, 1999.

"Participar-pesquisar". In BRANDÃO, C. R. (org.). Repensando a pesquisa participante. $3^{a}$ ed. $1^{\text {a }}$ reimp., São Paulo: Brasiliense, 1999.

. "A participação da pesquisa no trabalho popular". In BRANDÃO, C. R. (org.). Repensando a pesquisa participante. $3^{\mathrm{a}}$ ed. $1^{\mathrm{a}}$ reimp., São Paulo: Brasiliense, 1999.

BRASIL. Ministério da Educação. Sinaes - Sistema Nacional de Avaliação da Educação Superior: bases para uma nova proposta de avaliação da Educação Superior Brasileira. Brasília, 2004. 
. Corde. Declaração de Salamanca e linha de ação sobre necessidades educativas especiais. Brasília, 1994.

Mapa do Analfabetismo. Brasília, 2003.

BUENO, J. G. S. Crianças com necessidades educativas especiais: política educacional e formação de professores: generalistas ou especialistas? Texto apresentado no grupo de trabalho da Associação Nacional de Pós-Graduação em Educação (ANPEd), 1998.

" "A integração social das crianças deficientes: a função da educação especial". In MANTOAN, M. T. E. e cols. A integração das pessoas com deficiência: contribuições para uma reflexão sobre o tema. São Paulo: Memnon/Senac, 1997.

CAMPOS, M. M. M. "Pesquisa participante: possibilidade para o estudo na escola". Cadernos de Pesquisa, n. 49. São Paulo: Fundação Carlos Chagas, maio 1984.

CANDAU, V. M. Magistério construção cotidiana. Petrópolis: Vozes, 1997.

CHARLOT, B. Da relação com o saber: elementos para uma teoria. Porto Alegre: Artes Médicas Sul, 2000.

CHAUÍ, M. A universidade pública sob nova perspectiva. Conferência de abertura da Associação Nacional de Pós-Graduação em Educação (ANPEd). Poços de Caldas, 2003.

Brasil: mito fundador e sociedade autoritária. São Paulo: Fundação Perseu Abramo, 2001.

CHIZZOTTI, A. Pesquisa em ciências humanas e sociais. 2a ed., São Paulo: Cortez, 1995.

Colcha de Retalhos. "How to make an American Quilt", um filme dirigido por Jocelyn Moorhouse, produzido por Sanford/Pillsbury. Estados Unidos, 1995.

COMPARATO, F. K. Educação, Estado e poder. São Paulo: Brasiliense, 1987. A afirmação histórica dos direitos humanos. São Paulo: Saraiva, 2001.

CONSELHO FEDERAL DE PSICOLOGIA. I Seminário Nacional de Psicologia e Políticas Públicas: políticas públicas como um desafio para os psicólogos. Salvador: CFP/CRP 3a, 2001.

CONSELHO REGIONAL DE PSICOLOGIA DE SÃo PAULO. Educação especial em debate. São Paulo: Casa do Psicólogo/Conselho Regional de Psicologia, 1997. 
CORRER, R. Deficiência e inclusão social: construindo uma nova comunidade. Bauru: Edusc, 2003.

CORTELLA, M. S. A escola e o conhecimento: fundamentos epistemológicos e políticos. 6ª ed., São Paulo: Cortez/Instituto Paulo Freire, 2002.

DEMO, P. Desafios modernos da educação. Petrópolis: Vozes, 1993.

"Qualidade e representação da pesquisa em educação". Cadernos de Pesquisa, n. 55. São Paulo: Fundação Carlos Chagas, nov. 1998.

Metodologia científica em Ciências Sociais. São Paulo: Atlas, 1985.

"Elementos metodológicos da pesquisa participante". In BRANDÃO, C. R. (org.). Repensando a pesquisa participante. $3^{a}$ ed. $1^{\text {a }}$ reimp., São Paulo: Brasiliense, 1999.

DOMINGUES, I. O horário coletivo de trabalho e a (re) construção da profissionalidade docente. Dissertação de Mestrado. São Paulo, Faculdade de Educação da Universidade de São Paulo, 2004.

ESCOLA MUNICIPAL DE ENSINO FUNDAMENTAL "VIANNA MOOG". Plano Escolar de 2002. São Paulo, 2002.

ESTRELA, M. T. Relação pedagógica, disciplina e indisciplina. Porto: LDA, 1992.

FERNANDES, H. R. (org.) e FERNANDES, F. (coord.). Wright Mills: Sociologia. São Paulo: Ática, 1985.

FERREIRA, N. S. C. e AGUIAR, M. A. S. (orgs.). Gestão da educação: impasses, perspectivas e compromissos. São Paulo: Cortez, 2000.

FERREIRO, E. Com todas as letras. 9a ed., São Paulo: Cortez, 2001.

FORACCHI, M. M. e MARTINS, J. S. Sociologia e sociedade. Rio de Janeiro: Livros Técnicos e Científicos, 1983.

FÓRUM ESTADUAL EM DEFESA DA ESCOLA PÚBLICA (Fedep/SP) Carta de Princípios do Fedep/SP. São Paulo: 1990, mimeo.

Plano Estadual de Educação - Proposta da Sociedade Paulista. São Paulo: Adusp, 2003. 
FÓRUM NACIONAL EM DEFESA DA ESCOLA PÚBLICA Plano Nacional de Educação Proposta da Sociedade Brasileira. Belo Horizonte/MG, 1997. Caderno do 40 Coned. São Paulo, 2002.

. Carta de Porto Alegre. Caderno do III CONED. Porto Alegre, 1999. Caderno do $5^{0}$ Congresso Nacional de Educação. Recife/PE, 2004.

FREIRE, P. À sombra desta mangueira. São Paulo: Olho d'Água, 2001.

. Pedagogia da indignação: cartas pedagógicas e outros escritos. São Paulo: Unesp, 2000. . Pedagogia do oprimido. 34a ed., Rio de Janeiro: Paz e Terra, 2002. "Criando métodos de pesquisa alternativa: aprendendo a fazê-la melhor através da ação". In BRANDÃO, C. R. (org.). Pesquisa Participante. $5^{a}$ ed., São Paulo: Brasiliense, 1985.

FREITAG, B. Escola, Estado e sociedade. 4ª ed. rev., São Paulo: Moraes, 1980.

FRIGOTTO, G. e GENTILI, P. (orgs.). A cidadania negada - políticas de exclusão na educação. São Paulo: Cortez, 2001.

FRIGOTTO, G. "A formação e a profissionalização do educador: novos desafios". In GENTILI, P. e SILVA, T. T. (orgs.). Escola S.A.: quem ganha e quem perde no mercado educacional do neoliberalismo. Brasília: CNTE, 1996.

GADOTTI, M. História das idéias pedagógicas. São Paulo: Ática, 2002.

GENTILI, P. e SILVA, T. T. (orgs.). Escola S.A.: quem ganha e quem perde no mercado educacional do neoliberalismo. Brasília: CNTE, 1996.

GIMENO, S. J. e GÓMEZ, A. I. P. Compreender e transformar o ensino. Porto Alegre: Artmed, 1997.

GOHN, M. G. "Educação, trabalho e lutas sociais". In FRIGOTTO, G. e GENTILI, P. (orgs.). A cidadania negada - políticas de exclusão na educação. São Paulo: Cortez, 2001.

GÓMEZ, A. I. P. "A função e a formação do professor/a no ensino para a compreensão: diferentes perspectivas". In GIMENO, S. J. e GÓMEZ, A. I. P. Compreender e transformar o ensino. Porto Alegre: Artmed, 1997.

GRAMSCI, A. Os intelectuais e a organização da cultura. Rio de Janeiro: Civilização Brasileira, 1988. 
GUIRARDO, M. Instituições e relações afetivas: o vínculo com o abandono. São Paulo: Summus, 1986.

HAYEK, F. A. Camino de servindubre. 2a reimp., Madrid: Alianza, 1990.

HELLER, A. O cotidiano e a história. Rio de Janeiro: Paz e Terra, 1972.

HERNÁNDEZ, F. Cultura visual, mudança educativa e projeto de trabalho. Porto Alegre: Artes Médicas Sul, 2000.

HOBSBAWM, E. "Adeus a tudo aquilo". In BLACKBURN, R. Depois da queda: 0 fracasso do comunismo e o futuro do socialismo. $2^{a}$ ed., Rio de Janeiro: Paz e Terra, 1993.

HOBSBAWM, E. Nações e nacionalismo desde 1780. $2^{\mathrm{a}}$ ed., Rio de Janeiro: Paz e Terra, 1990.

IANNI, O. Palestra proferida no seminário Charles Wright Mills: um sociólogo no centro do capitalismo. São Paulo, Faculdade de Educação da Universidade de São Paulo, 2003.

JACOBY, R. Os últimos intelectuais: a cultura americana na era da academia. São Paulo: Trajetória Cultural/Edusp, 1990.

JODELET, D. "Os processos psicossociais da exclusão". In SAWAYA, B. B. As artimanhas da exclusão - análise psicossocial e ética da desigualdade social. São Paulo: Vozes, 2001.

KUHN, T.S. $A$ estrutura das revoluções científicas. São Paulo: Perspectiva, 1982.

LANE, S. T. M. e CODO, W. (orgs.). Psicologia Social - o homem em movimento. São Paulo: Brasiliense, 1989.

LANE, S. T. M. e SAWAIA, B. B. (orgs.). Novas veredas da Psicologia Social. São Paulo: Educ/Brasiliense, 1995.

LEHER, R. "Tempo, autonomia, sociedade civil e esfera pública: uma introdução ao debate a propósito dos "novos" movimentos sociais na educação". In FRIGOTTO, G. e GENTITLI, P. (orgs.). A cidadania negada - políticas de exclusão na educação. São Paulo: Cortez, 2001

LINHARES, C.; FAZENDA, I. e TRINDADE, V. (orgs.). Os lugares dos sujeitos na pesquisa educacional. Campo Grande: UFMS, 2001. 
LÜDKE, M e ANDRÉ, M. E. D. A. Pesquisa em educação: abordagens qualitativas. São Paulo: EPU, 1986.

MANIFESTO DOS PIONEIROS DA EDUCAÇÃO NOVA. Revista Brasileira de Estudos Pedagógicos, vol. 65, n. 150. Brasília, 1984.

MANTOAN, M. T. E. Inclusão Escolar: O que é? Por quê? Como fazer? São Paulo: Moderna, 2003.

e cols. A integração de pessoas com deficiência: contribuições para uma reflexão sobre o tema. São Paulo: Memnon/Senac, 1997.

(org.). Caminhos pedagógicos da inclusão. São Paulo: Memnon, 2001.

MARTINS, H. H. S. "Metodologia Qualitativa de Pesquisa". Seminário Internacional Questões Teórico-Metodológicas na Pesquisa em Educação. São Paulo, Faculdade de Educação da Universidade de São Paulo, 2003.

MARTINS, J. S. Exclusão Social e a nova desigualdade. São Paulo: Paulus, 1997.

MARX, K. O capital - crítica da economia política. Vols. I e II. 9a ed., São Paulo: Difel, 1984.

MAZZOTTA, M. J. S. Fundamentos de educação especial. São Paulo: Pioneira, 1982.

Cortez, 1996. Educação especial no Brasil: história e políticas públicas. São Paulo:

. "Dilemas e perspectivas da educação do portador de deficiência no novo milênio". Anais do Fórum Nacional de Educação - Educação no Século XXI: Desafios e Perspectivas. João Pessoa (PB), 2001.

MINTO, C. A. Legislação educacional e cidadania virtual, anos 90. Tese de Doutorado. São Paulo: Faculdade de Educação da Universidade de São Paulo, 1996.

MITTLER, P. Educação inclusiva: contextos sociais. Porto Alegre: Artmed, 2003.

MIZUKAMI, M. G. N. Ensino: as abordagens do processo. São Paulo: EPU, 1986.

MOREIRA, A. F. e SILVA, T. T. (orgs.). Currículo, cultura e sociedade. São Paulo: Cortez, 2002.

MOREIRA, R. Planejamento educacional no Brasil. São Paulo: OEA, 1989. 
MRECH, L. M. O mercado de saber, o real da educação e dos educadores e a escola como possibilidade. Tese de livre-docência. São Paulo: Faculdade de Educação da Universidade de São Paulo, 2001.

NAGLE, J. Educação e sociedade no Brasil, 1920-1929. Araraquara: FFCL, 1966.

NÓvOA, A. (org.). Os professores e sua formação. Lisboa: Dom Quixote, 1992.

. "Os professores na virada do milênio: dos excessos de discursos à pobreza das práticas". Revista Pesquisa e Educação, vol. 25, n. 1. São Paulo: jan./jun. 2000.

NÚCLEO DE ESTUDOS JEAN MAUGÜÉ. Abertura. São Paulo: Núcleo de Estudos Jean Maugüé, 1996.

NÚÑEZ, C. (coord.) e cols. Nuestras prácticas: perfil y perpectivas de la formación de educadores populares en latinoamerica. México: Instituto Mexicano para el Desarollo Comunitario, 1993.

O'BRIEN, J. e O'BRIEN, C. L. "A Inclusão como uma força para a renovação da escola". In STAINBACK, S. e STAINBACK, W. Inclusão: um guia para educadores. Porto Alegre: Artes Médicas Sul, 1999.

OLIVEIRA, F. "Vanguarda do atraso e atraso da vanguarda: globalização e neoliberalismo na América Latina". XXI Congresso da Associação Latino-Americana de Sociologia - Alas. São Paulo, 1997.

OLIVEIRA, M. K.; SOUZA, D. T. R. e REGO, T. C. (orgs.). Psicologia, educação e as temáticas da vida contemporânea. São Paulo: Moderna, 2002.

OLIVEIRA, R. D. e OLIVEIRA M. D. "Pesquisa social e ação educativa: conhecer a realidade para poder transformá-la". In BRANDÃO, C. R. (org.). Pesquisa participante. $5^{a}$ ed., São Paulo: Brasiliense, 1985.

OLIVEIRA, R. P. e ADRIÃO, T. (orgs.). Gestão, financiamento e direito à educação: análise da LDB e da Constituição Federal. São Paulo: Xamã, 2001.

PAIVA, V. "Qualificação, crise do trabalho assalariado e exclusão social". In FRIGOTTO, G. e GENTILI, P. (orgs.). A cidadania negada - políticas de exclusão na educação. São Paulo: Cortez, 2001.

PARO, V. H. Por dentro da escola pública. São Paulo: Xamã, 1995.

PATTO, M. H. S. A produção do fracasso escolar: histórias de submissão e rebeldia. São Paulo: T. A. Queiroz, 1990. 
PERRENOUD, P. Dez novas competências para ensinar. Porto Alegre: Artes Médicas Sul, 2000.

PESSOTTI, I. Deficiência mental: da superstição à ciência. São Paulo: T. A. Queiroz, 1984.

PIMENTA, S. G. O pedagogo na escola pública. São Paulo: Loyola, 2002.

(org.). Saberes pedagógicos e atividade docente. São Paulo: Cortez,

1999.

PRIETO, R. G. Política educacional do Município de São Paulo: estudo sobre o atendimento de alunos com necessidades educativas especiais, no período de 1986 a 1996. Tese de Doutorado. São Paulo: Faculdade de Educação da Universidade de São Paulo, 2000.

PRIETO, R. G.; GARCEZ, L. et al. Educação inclusiva: o desafio de ampliar o atendimento de alunos com qualidade e a formação docente. Pesquisa sobre políticas públicas em Educação, aprovado pela Área de Políticas Públicas da Fapesp/2002 (n. Processo 2001/02953-8).

PUIG, J. Ética e valores: métodos para um ensino transversal. São Paulo: Casa do Psicólogo, 1998.

REGO, T. C. Vygostsky: uma perspectiva histórico-cultural da educação. Petrópolis: Vozes, 1995.

Revista da Faculdade de Educação/Universidade de São Paulo. São Paulo, n. 2, vol. 22, 1996.

Revista da Faculdade de Educação/Universidade de São Paulo. São Paulo, n. 2, vol. 26, 2000.

Revista Psicologia: teoria e prática. São Paulo, n. 1, vol. 1. Faculdade de Psicologia da Universidade Presbiteriana Mackenzie, 1999.

RIBEIRO, M. L. S. História da educação brasileira: a organização escolar. $8^{a}$ ed., São Paulo/Campinas: Cortez/Autores Associados, 1988.

RIOS, T. A. Compreender e ensinar: por uma docência da melhor qualidade. $2^{\mathrm{a}}$ ed., São Paulo: Cortez, 2001.

SANTOS, B. S. $A$ introdução a uma ciência pós-moderna. Rio de Janeiro: Paz e Terra, 1995. 
São Paulo: Cortez, 2001.

SÃO PAULO/SP. Secretaria Municipal de Educação. Caderno EducAção, n. 1. São Paulo, 2001.

. Caderno EducAção, n. 2. São Paulo, 2001.

. Caderno EducAção, n. 3, São Paulo,2002.

. Caderno EducAção, n. 4, São Paulo, 2003.

. Caderno temático de formação I. São Paulo, 2003.

. Construindo uma educação popular pública. São Paulo, 1989.

. Proposta preliminar de formação permanente dos educadores da rede municipal de ensino. São Paulo, 2001.

SÃO PAULO/SP. Coordenadoria Especial da Mulher. Nem mais, nem menos: iguais: cartilha para alunos. São Paulo, 2002.

SASSAKI, R. K. Inclusão: construindo uma sociedade para todos. $3^{a}$ ed., Rio de Janeiro: WVA, 1999.

SAVIANI, D. Escola e democracia: teorias da educação, curvatura da vara, onze teses sobre educação e política. $21^{a}$ ed., São Paulo/Campinas: Cortez/Autores Associados, 1989.

Associados, 1997.

Educação brasileira: estrutura e sistema. Campinas: Autores

SAWAIA, B. (org.). As artimanhas da exclusão: análise psicossocial e ética da desigualdade social. Petrópolis: Vozes, 2001.

. "Introdução: exclusão ou inclusão perversa?" In SAWAIA, B. (org.). As artimanhas da exclusão: análise psicossocial e ética da desigualdade social. Petrópolis: Vozes, 2001.

"O sofrimento ético-político como categoria de análise da dialética exclusão/inclusão". In SAWAIA, B. (org.). As artimanhas da exclusão: análise psicossocial e ética da desigualdade social. Petrópolis: Vozes, 2001.

SCHAFFNER, C. B. e BUSWELL, B. E. "Dez elementos críticos para a criação de comunidades de ensino inclusivo e eficaz". In STAINBACK, S. e STAINBACK, W. Inclusão: um guia para educadores. Porto Alegre: Artes Médicas Sul, 1999. 
SILVA JÚNIOR, J. R. "Reformas educacionais, reconversão produtiva e a constituição de um novo sujeito". In FRIGOTTO, G. e GENTITLI, P. (orgs.). A cidadania negada políticas de exclusão na educação. São Paulo: Cortez, 2001.

SKLIAR, C. (org.). Educação \& exclusão: abordagens sócio-antropológicas em educação especial. Porto Alegre: Mediação, 1997.

SPOSATI, A. O. (coord.). Mapa da exclusão/inclusão social da cidade de São Paulo. São Paulo: Educ, 1996.

STAINBACK, S. e STAINBACK, W. Inclusão: um guia para educadores. Porto Alegre: Artes Médicas Sul, 1999.

TANAMACHI, E. R.; ROCHA, M. L. e PROENÇA, M. Psicologia e educação: desafios teórico-práticos. São Paulo: Casa do Psicólogo, 2000.

THIOLLENT, M. Metodologia da pesquisa-ação. 9a ed., São Paulo: Cortez, 2000.

"Notas para o debate sobre pesquisa-ação". In BRANDÃO, C. R. (org.). Repensando a pesquisa participante. $3^{a}$ ed. $1^{\text {a }}$ reimp., São Paulo: Brasiliense, 1999.

VALENTE, I. A nova LDB em questão. Brasília: Senado Federal/Secretaria Especial de Editoração e Publicações, 2001.

VASCONCELLOS, V. M. R. e VALSINER, J. Perspectiva co-construtivista na psicologia e na educação. Porto Alegre: Artes Médicas Sul, 1995.

VYGOTSKY, L. S. A formação social da mente: o desenvolvimento dos processos psicológicos superiores. 6ª ed., São Paulo: Martins Fontes, 1998. 